\title{
EXIGÊNCIAS E EFICIÊNCIA ENERGÉTICA DE VACAS DE CORTE NELORE E DE CRUZAMENTOS BOS TAURUS X NELORE
}

\author{
LiANA NOGUEIRA DE PAUlA CALEGARE
}

Dissertação apresentada à Escola Superior de Agricultura "Luiz de Queiroz", Universidade de São Paulo, para obtenção do título de Mestre em Agronomia, Área de Concentração: Ciência Animal e Pastagens.

P I R A C I C A B A

Estado de São Paulo - Brasil

Maio - 2004 


\title{
EXIGÊNCIAS E EFICIÊNCIA ENERGÉTICA DE VACAS DE CORTE NELORE E DE CRUZAMENTOS BOS TAURUS X NELORE
}

\section{LiANA NOGUEIRA DE PAUlA CALEGARE}

Médica Veterinária

\author{
Orientador: Prof. Dr. DANTE PAZZANESE LANNA
}

\begin{abstract}
Dissertação apresentada à Escola Superior de Agricultura "Luiz de Queiroz", Universidade de São Paulo, para obtenção do título de Mestre em Agronomia, Área de Concentração: Ciência Animal e Pastagens.
\end{abstract}

P I R A C I C A B A

Estado de São Paulo - Brasil

Maio - 2004 


\section{Dados Internacionais de Catalogação na Publicação (CIP) DIVISÃO DE BIBLIOTECA E DOCUMENTAÇÃO - ESALQ/USP}

\section{Calegare, Liana Nogueira de Paula}

Exigências e eficiências energéticas de vacas de corte Nelore e de cruzamentos

Bos Taurus x Nelore / Liana Nogueira de Paula Calegare. - - Piracicaba, 2004.

79 p. : il.

Dissertação (mestrado) - - Escola Superior de Agricultura Luiz de Queiroz, 2004.

Bibliografia.

1. Bezerro 2. Bovino de corte 3. Composição corporal 4. Cruzamento animal Genótipo 6. Leite (Produção) 7. Nutrição animal I. Título

CDD 636.213 
A Deus,

Fonte de luz, inspiração e perseverança.

A meus pais Ayres e Eunice

Pela dedicação, amor e confiança em cada decisão tomada por mim.

DEDICO 


\section{AGRADECIMENTOS}

Ao orientador e amigo Prof. Dr. Dante Pazzanese D. Lanna pela confiança e pelos conhecimentos compartilhados durante o Mestrado;

Ao Pesquisador e chefe do Projeto Dr. Maurício Mello de Alencar pela convivência e apoio na execução deste trabalho;

Aos Professores Paulo Roberto Leme e Irineu Umberto Packer pelas sugestões e carisma;

Ao Prof. Wilson Mattos pelos conselhos e contribuições;

À minha irmã Lucila pela confiança depositada em meus sonhos;

Ao meu irmão Fábio, minha cunhada Renata e queridas sobrinhas Júlia e Luisa;

À minha querida Liris irmã e amiga;

Ao meu colega de trabalho e querido amigo Prof. “de Almeida” por toda ajuda e paciência;

Às amigas Amanda, Andrea e Marina pela amizade e cumplicidade;

Aos amigos “Bio”, Dimas, Juliano e Marco Antônio, pela amizade e colaboração;

Aos colegas do laboratório, Adriana, Beatriz, Eric, Laudi, Rodrigo e Oscar pela convivência;

À Ana e Tuka pelo carinho; 
Às Pesquisadoras da Embrapa Dra. Carla Nussio e Dra. Patrícia Santos pela convivência e colaboração;

Aos Pesquisadores Dr. Geraldo M. Cruz e Dr. Armando Rodrigues pelo suporte na condução do experimento;

À querida Sônia Borges de Alencar pela amizade;

Aos estagiários e amigos Betina, Cláudia, Eduardo, Glaiser, Guiga, Pipi, Sílvio e aos funcionários da Embrapa e do IZ/Nova Odessa; Adão, Avaré, Bola, Carlão, Celso, Cláudio, Cristina, Gilberto, João, Lourdes, Mineiro, Nacir, Nelsinho, Rafael, Zezão, Dna. Olinda, Muzambinho e outros que possa ter, aqui, esquecido e que tanto colaboraram para o desenvolvimento deste trabalho;

À FAPESP pelo suporte durante o desenvolvimento do Projeto Temático;

À CAPES, pela concessão da bolsa de estudos. 


\section{SUMÁRIO}

Página

LISTA DE ABREVIATURAS .............................................................. ix

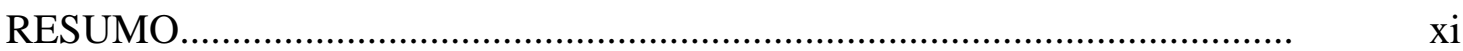

SUMMARY .......................................................................................

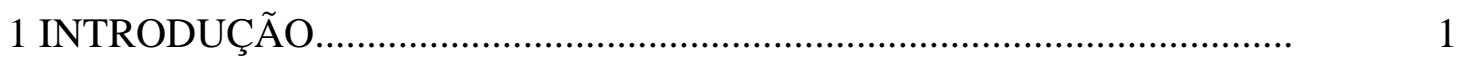

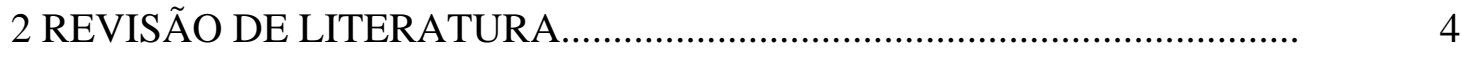

2.1 Exigência energética........................................................................ 4

2.1.2 Variação da composição corporal e da demanda por nutrientes............... 5

2.1.3 Fatores que afetam a exigência energética de mantença......................... 5

2.1.3.1 Fatores associados a características do animal e estágio de maturidade............................................................................. 7

2.1.3.2 Influência da composição corporal sobre a exigência de mantença...... 8

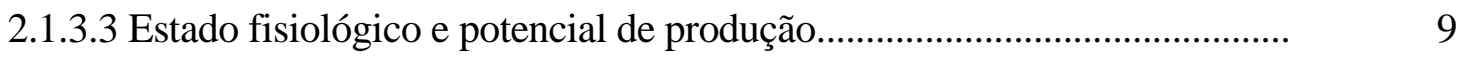

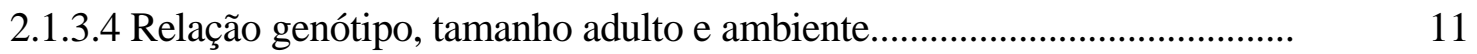

2.2 Eficiência do sistema......................................................................... 12

2.2.1 Eficiência de produção nas condições tropicais brasileiras...................... 12

2.2.2 Fatores que influenciam a eficiência de produção................................... 13

2.3 Critérios de seleção e eficiência de produção............................................ 15

3. MATERIAL E MÉTODOS..................................................................... 18

3.1 Local..................................................................................... 18

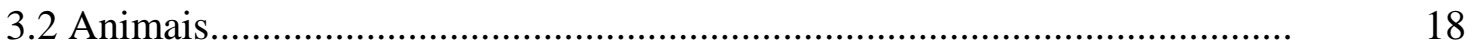

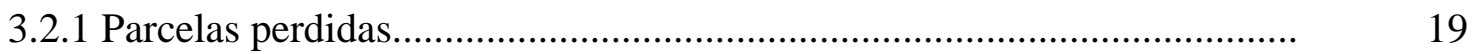


3.3 Instalações.

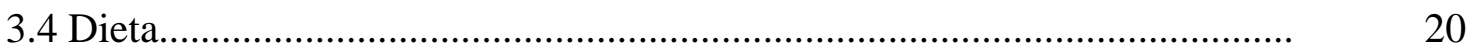

3.5 Manejo e coleta de dados........................................................................ 21

3.5.1 Parâmetros utilizados para determinar o consumo de MS e se estimar a mobilização ou retenção de energia corporal.........................................

3.5.2 Parâmetros utilizados para determinar a produção e a composição do leite..

3.5.3 Análises laboratoriais e estimativa do valor nutricional da dieta......

3.5.4 Abate experimental e estimativa da composição do corpo vazio.....

3.6 Análise estatística....

3.6.1 Modelo estatístico.

4 RESULTADOS E DISCUSSÃO.

4.1 Peso e escore de condição corporal............................................................. 30

4.2 Produção e composição do leite.................................................................... 31

4.3 Ingestão de matéria seca.............................................................................

4.4 Exigência de energia metabolizável............................................................ 36

4.5 Desempenho dos bezerros: índices de ingestão e eficiência.......................... 42

4.6 Características da carcaça dos bezerros Nelore, 3/4/1/4/4, 1/2 $\mathrm{C}^{1} / 4 \mathrm{~A}^{1} / 4 \mathrm{~N}$ e

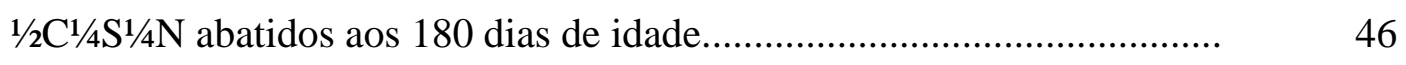

4.6.1 Características mensuradas post mortem.................................................. 46

4.6.2 Massa dos órgãos internos e sua relação com o peso metabólico............... 48

4.7 Estimativa da composição corporal dos bezerros ao desmame..................... 49

4.7.1 Valores percentuais da composição química da 9- 10- 11 a costelas e do

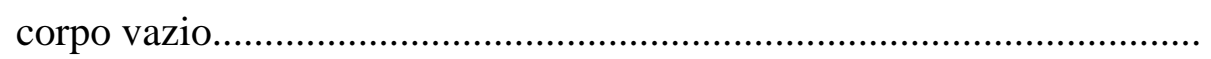

4.7.2 Quantidades de água, extrato etéreo, proteína, cinzas e energia do corpo vazio.

4.8 Ingestão e eficiência do par vaca/bezerro....................................................... 53

4.8.1 Índices com base na matéria seca.............................................................

4.8.2 Índices com base na energia metabolizável............................................... 55 
4.8.3 Eficiência energética - kcal do corpo vazio/Mcal de EM ingerida pela

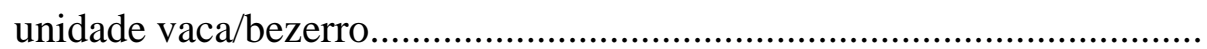

4.8.4 Eficiência protéica - gramas de proteína depositada no corpo vazio/kg de proteína ingerida pela unidade vaca/bezerro.......................................... 61

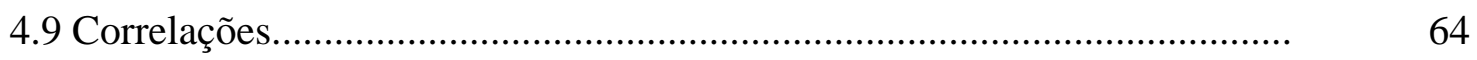

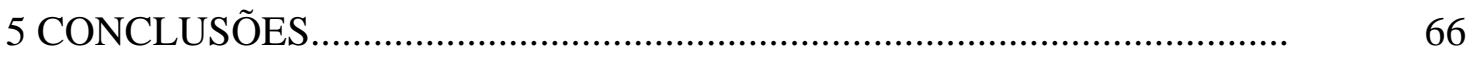

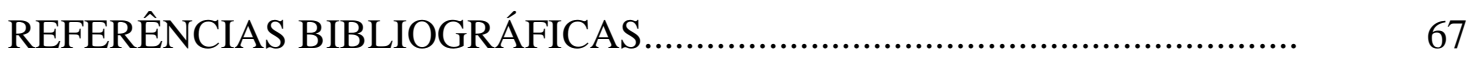




\section{LISTA DE ABREVIATURAS}

AA: aminoácidos

AOL: área de olho de lombo

AN: vaca Angus x Nelore

AN/1/2C1/4N1/4A: par vaca/bezerro Angus x Nelore/1/2Canchim + 1/4Angus + 1/4 Nelore

C.A.: conversão alimentar

$\mathrm{CN}$ : vaca Canchim x Nelore

$\mathrm{CN} / 3 / 4 \mathrm{C} 1 / 4 \mathrm{~N}$ : par vaca/bezerro Canchim x Nelore/3/4Canchim + 1/4Nelore

$3 / 4 \mathrm{C} 1 / 4 \mathrm{~N}$ : bezerro $3 / 4$ Canchim $+1 / 4$ Nelore

$1 / 2 \mathrm{C} 1 / 4 \mathrm{~A} 1 / 4 \mathrm{~N}$ : bezerro $1 / 2$ Canchim $+1 / 4$ Angus $+1 / 4$ Nelore

$1 / 2 \mathrm{C}^{1} / 4 \mathrm{~S} 1 / 4 \mathrm{~N}$ : bezerro $1 / 2$ Canchim $+1 / 4$ Simental $+1 / 4$ Nelore

EB: energia bruta

ECC: escore de condição corporal (escala de 1 a 9 pontos)

ED: energia digestível

EE: extrato etéreo

EGS: espessura de gordura subcutânea

EL: energia líquida

ELl: energia líquida de lactação

EL $L_{m}$ energia líquida de mantença

ELmob: energia líquida mobilizada

EM: energia metabolizável

EM: energia metabolizável de lactação 
$\mathrm{EM}_{\mathrm{m}}$ : energia metabolizável de mantença

$\mathrm{EM}_{\text {mob }}$ : energia metabolizável de mobilizada

$\mathrm{EM}_{\mathrm{R}}$ : energia metabolizável retida

FDA: fibra insolúvel em detergente ácido

FDN: fibra insolúvel em detergente neutro

g: gramas

GP: ganho de peso

$\mathrm{GP}_{180}$ : ganho de peso durante os primeiros 180 dias de lactação

IEM: ingestão de energia metabolizável

IMS: ingestão de matéria seca

kcal: quilocaloria

kg: quilograma

Mcal: megacaloria

MM: matéria mineral

MS: matéria seca

NDT: nutrientes digestíveis totais

NE: vaca Nelore

NE/Nelore: par vaca/bezerro Nelore/Nelore

N-FDA: nitrogênio ligado à fibra insolúvel em detergente ácido

N-FDN: nitrogênio ligado à fibra insolúvel em detergente neutro

PB: proteína bruta

PNDR: proteína não degradável no rúmen

PV: peso vivo

$\mathrm{P}_{\text {vazio }}$ : peso do corpo vazio

$\mathrm{P}^{0,75}$ : peso metabólico

SN: vaca Simental x Nelore

$\mathrm{SN} / 1 / 2 \mathrm{C}^{1} / 4 \mathrm{~S} 1 / 4 \mathrm{~N}$ : par vaca/bezerro Simental x Nelore/1/2Canchim + 1/4 Simental + 1/4Nelore 


\title{
EXIGÊNCIAS E EFICIÊNCIA ENERGÉTICA DE VACAS DE CORTE NELORE E DE CRUZAMENTOS BOS TAURUS $\times$ NELORE
}

\author{
Autora: LIANA NOGUEIRA DE PAULA CALEGARE \\ Orientador: Prof. Dr. DANTE PAZZANESE D. LANNA
}

\section{RESUMO}

Quarenta vacas lactantes e não gestantes, com idade aproximada de quatro anos e seus respectivos bezerros foram distribuídos em blocos, de acordo com a data do parto, e avaliadas dos 15 aos 180 dias de lactação. As vacas pertenciam a quatro grupos genéticos: 10 da raça Nelore (NE) com bezerros de touros Nelore; e 10 Canchim x Nelore (CN), 10 Angus x Nelore (AN) e 10 Simental x Nelore (SN) com bezerros filhos de touros da raça Canchim. As vacas cruzadas e as Nelore eram de origem do mesmo rebanho Nelore. As vacas foram alimentadas com uma única dieta peletizada contendo $50 \%$ de feno (15\% de alfafa e $35 \%$ de Coastcross) e $50 \%$ de concentrado, com 16,1\% PB e 2,24 Mcal EM, com base na MS. A quantidade de alimento fornecida foi ajustada a cada 14 dias para que o peso vivo em jejum $\left(\mathrm{PV}_{\mathrm{j}}\right)$ e o escore de condição corporal (ECC) da vaca ficassem inalterados. O PV $\mathrm{P}_{\mathrm{j}}$ e ECC para as vacas NE, CN, AN e SN foram: 430 e 4,7; 449 e 4,8; 496 e 5,0; 507 e 5,1; respectivamente. Os bezerros receberam a mesma dieta a partir dos 40 dias de idade. A produção de leite das vacas foi determinada pelo método de pesagem dos bezerros antes e após a mamada aos 52, 66, 94, 122 e 178 dias 
de lactação, em média. Foi realizada ordenha manual aos 80 e 150 dias, para se estimar a composição do leite. As vacas NE consumiram menos energia metabolizável (19,7 Mcal/d; P<0,05) do que as vacas CN (20,6 Mcal/d), AN (23,1 Mcal/d) e SN (23,7 $\mathrm{Mcal} / \mathrm{d})$, valores positivamente correlacionados à produção de leite $(\mathrm{P}<0,05)$. Bezerros Nelore apresentaram menor peso ao desmame $(\mathrm{P}<0,05)$ do que os bezerros $3 / 4$ Canchim $1 / 4$ Nelore $\quad\left(3 / 4 \mathrm{C}^{1 / 4} \mathrm{~N}\right), \quad 1 / 2$ Canchim $1 / 4$ Angus $1 / 4$ Nelore $\quad\left(1 / 2 \mathrm{C}^{1 / 4} / \mathrm{A}^{1} \frac{1}{4} \mathrm{~N}\right) \quad$ e $1 / 2$ Canchim $1 \frac{1}{4}$ Simental $1 \frac{1}{4}$ Nelore $\left(1 / 2 \mathrm{C}^{1} / 4 \mathrm{~S}^{1} / 4 \mathrm{~N}\right) \quad(165,8$ vs. 205,5; 216,4 e $215,4 \mathrm{~kg}$, respectivamente). Associado ao menor ganho de peso durante o aleitamento, os bezerros Nelore apresentaram menor $(\mathrm{P}<0,05)$ ingestão de energia metabolizável (Mcal de leite + Mcal de ração). Os bezerros foram abatidos ao desmame e a composição química do corpo vazio estimada utilizando a 9- 10- $11^{\text {a }}$ costelas. A energia no corpo vazio foi maior $(\mathrm{P}<0,05)$ para os bezerros 1/2/21/4A1/4N (462,6 Mcal) em relação aos 3/4 $\mathrm{C}^{1} / 4 \mathrm{~N}$ (384,0 Mcal) e Nelore (321,8 Mcal); a quantidade de energia no corpo vazio para os bezerros 1/2 $\mathrm{C}^{1} / 4 \mathrm{~S} 1 / 4 \mathrm{~N}$ foi intermediária; 429,8 Mcal. A eficiência energética da unidade vaca/bezerro foi maior $(\mathrm{P}<0,05)$ para o grupo materno AN $(124,4 \mathrm{kcal}$ de bezerro desmamado/Mcal EM ingerida por vaca e bezerro) comparada ao par NE/Nelore (95,8 kcal/Mcal). Os pares Canchim e Simental foram intermediários, 105,2 e 107,0 $\mathrm{kcal} / \mathrm{Mcal}$, respectivamente. Portanto, a maior energia no corpo vazio e maior ganho de peso dos bezerros $1 / 2 \mathrm{C}^{1} / 4 \mathrm{~A}^{1} / 4 \mathrm{~N}$ mais do que compensou a ingestão mais elevada de energia metabolizável da unidade vaca/bezerro em comparação ao Nelore. Pode-se considerar que para as condições estabelecidas neste experimento, cujo delineamento não apresentava limitação nutricional, o cruzamento melhorou a eficiência da vaca, quando considerada a proporção de energia total consumida que foi depositada nos bezerros. Entretanto, não houve avaliação de parâmetros reprodutivos, e o menor consumo e exigência de MS e EM estabelecido para a vaca Nelore sugere que em ambiente nutricional desfavorável este genótipo poderia apresentar melhor produtividade. 


\title{
ENERGY REQUIREMENTS AND ENERGETIC EFFICIENCY OF NELLORE AND CROSSBRED BOS TAURUS X NELLORE BEEF COWS
}

\author{
Author: LIANA NOGUEIRA DE PAULA CALEGARE \\ Adviser: Prof. Dr. DANTE PAZZANESE D. LANNA
}

\section{SUMMARY}

Forty mature, lactating and non-pregnant cows (10 Nellore - NL; 10 Canchim x Nellore - CN; 10 Angus x Nellore - AN; and 10 Simmental x Nellore - SN) were randomized in blocks by calving date. Calves out of crossbred cows were sired by Canchim bulls, while calves out of NL cows were sired by Nellore bulls. Cows were individually fed from postpartum to weaning (15-180 d) a pelleted diet made of 50\% hay (15\% alfalfa and 35\% Coastcross) and 50\% concentrate. Diet had 16.1\% CP and 2.24 Mcal of metabolizable energy (ME) on a DM basis. Amount offered to each individual cow was adjusted every 14 days to maintain shrunk body weight (SBW) and body condition score (BCS). SBW and BCS were 430 and 4.7, 449 and 4.8, 496 and 5.0, and 507 and 5.1 for NL, CN, AN and SN, respectively. At 40 days of age calves had access to the same diet of their dams ad libitum. Milk yields were determined at 52, 66, 94, 122 and 178 days postpartum by weighting calves before and after suckling. Cows were milked at 80 and 150 days postpartum and the samples analyzed for fat, protein, and lactose. Daily ME intake by NL cows $(19.7 \mathrm{Mcal} / \mathrm{d})$ was lower $(\mathrm{P}<0.05)$ compared to CN (20.6Mcal/d), AN (23.1 Mcal/d) and SN (23.7 Mcal/d). These results were 
positively correlated with milk yield $(\mathrm{P}<0.05)$. Nellore calves had lower weaning weight

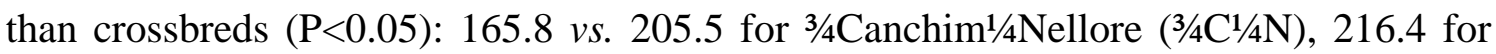
$1 / 2$ Canchim $1 / 4$ Angus $1 / 4$ Nellore $\quad\left(1 / 2 \mathrm{C}^{1 / 4} / 4 \mathrm{~A}^{1} / 4 \mathrm{~N}\right) \quad$ and $215.4 \quad \mathrm{~kg}$ for $1 / 2$ Canchim $1 / 4$ Simmental $1 / 4$ Nellore $\left(1 / 2 \mathrm{C}^{1} / 4 \mathrm{~S}^{1} / 4 \mathrm{~N}\right)$. In association with the lowest weight gain, Nellore calves had lower $(\mathrm{P}<0.05)$ metabolizable energy intake (ME from milk plus ration, Mcal). Calves were slaughtered at weaning and body composition estimated using the $9-10-11^{\text {th }}$ rib section. Body energy at weaning (Mcal) was higher $(\mathrm{P}<0.05)$ for $1 / 2 \mathrm{C}^{1} / 4 \mathrm{~A} 1 / 4 \mathrm{~N}$ than $3 / 4 \mathrm{C}^{1} / 4 \mathrm{~N}$ and Nellore calves: 462.6 vs. 384.0 and $321.8 \mathrm{Mcal}$, respectively. Calves $1 / 2 \mathrm{C}^{1} / 4 \mathrm{~S}^{1} / 4 \mathrm{~N}$ had intermediate body energy at weaning: $429.8 \mathrm{Mcal}$. Cow/calf energetic efficiency was higher $(\mathrm{P}<0.05)$ for AN compared to NL cow/calf pairs: 124.4 vs. $95.8 \mathrm{kcal}$ deposited/Mcal of ME consumed by cow and calf. Results for Canchim and Simmental were intermediate: 105.2 and $107.0 \mathrm{kcal} / \mathrm{Mcal}$, respectively. The higher ME intakes by Angus cow/calf pairs were more than compensated by the higher energy retention and body weight gain compared to NL. In an unrestricted nutritional setting, crossbreeding improved cow efficiency as measured by body energy/total feed energy input to cow and calf. Reproduction was not evaluated, and the lower intakes and daily energy requirements demonstrated for Nellore could be beneficial in a nutritionally limited environment. 


\section{INTRODUÇÃO}

O Brasil tem um rebanho bovino de 168 milhões de cabeças, das quais cerca de 53 milhões são de vacas de corte. Há dados de produção (“output”) de vacas de corte, entretanto, mesmo tendo enorme contribuição na composição do rebanho, da ordem de 31\%, há pouquíssimos dados sobre a eficiência dos diferentes genótipos utilizados, ou seja, muito pouco foi avaliado em termos de uso de recursos por vacas de corte (“input”).

A importância do setor de cria na eficiência de produção de bovinos de corte não pode ser subestimada, considerando-se que a alimentação representa cerca de $70 \%$ do custo total deste sistema e que aproximadamente $72 \%$ da energia necessária para a produção de um novilho ao abate é consumida pelo par vaca/bezerro (Ferrell \& Jenkins, 1982). Estas razões enfatizam a importância de se conhecer a eficiência durante o período de aleitamento, representada pela relação entre quilograma de bezerro desmamado e consumo do par vaca/bezerro.

Em todo o mundo, a agropecuária ocupa 1/3 dos solos disponíveis. Os agentes econômicos envolvidos no processo de produção e comercialização da carne bovina reconhecem os baixos índices de produtividade, não somente pela "limitação de terra", mas principalmente pelo tipo de sistema de produção empregado. Grande parte do rebanho de corte brasileiro é criada em sistema extensivo, o que explica parcialmente o baixo índice de produtividade. No entanto, este fato pode ser significativamente melhorado pela intensificação da produção a pasto associada à aplicação de tecnologias disponíveis, tais como: cruzamento industrial e terminação em confinamento dentre uma infinidade de outros. $\mathrm{O}$ uso do conhecimento poderia permitir a redistribuição do 
rebanho de cria em pastagens de melhor qualidade, melhor suprimento das exigências do par vaca/bezerro e melhora dos índices de eficiência biológica e econômica.

Nos últimos anos, tem ocorrido significativo aumento da produtividade acompanhado por melhora na qualidade. Investimentos em todos os setores da produção de carne, em virtude da globalização e do crescimento constante da população consumidora, serão essenciais para atender a maior demanda de produtos de alta qualidade. Segundo Delgado et al. (1999) uma revolução agrícola mundial está em curso desde a década de 1970 e a quantidade de carne consumida praticamente triplicou nos países em desenvolvimento, ou seja, houve incremento de aproximadamente 5,4\% ao ano. A perspectiva do aumento de consumo entre os anos de 1990 e 2020 é da ordem de 2,8\% ao ano para os países em desenvolvimento e até o ano de 2020, espera-se que estes países produzam $60 \%$ da carne mundial.

Inúmeras discussões sobre o melhor método de seleção genética $\mathrm{x}$ ambiente $\mathrm{x}$ sistema de produção vêm sendo abordadas, mas sem descrever a eficiência de conversão de cada genótipo em ambientes pré-estabelecidos. Os cruzamentos permitem a combinação de importantes características e a obtenção do vigor híbrido. Quanto à alimentação, sua importância relaciona-se aos custos de produção. A interação genótipo $\mathrm{x}$ ambiente e o conhecimento das exigências nutricionais permitem a utilização eficiente dos fatores de produção para cada situação específica.

No Brasil, muito pouco tem sido feito em relação às exigências nutricionais de vacas ao longo do ciclo anual de produção, envolvendo mantença, gestação e lactação. Portanto, é prioritário e urgente intensificar a pesquisa nesta área (Lanna, 2000). Mesmo em outros países, embora um considerável esforço tenha sido despendido na descrição de exigências para a manutenção e ganho de peso, em gado de corte em crescimento ou adulto, menos esforços foram feitos para estabelecer os requisitos necessários para os diferentes estados fisiológicos (lactação e gestação) em vacas de corte adultas (Jenkins \& Ferrell, 1983). Não obstante, um razoável volume de informações tem sido gerado apenas para animais nas condições de clima temperado.

Este experimento fez parte do projeto temático "Estratégias de Cruzamento, Práticas de Manejo e Biotécnicas para Intensificação Sustentada da Produção de Carne 
Bovina” desenvolvido com o apoio da FAPESP, e em colaboração entre Embrapa, USP, UNESP e IZ. O experimento foi conduzido no Centro de Pesquisa Pecuária Sudeste em São Carlos, SP, durante os meses de março a dezembro de 2002, utilizando fêmeas dos grupos genéticos Nelore, Canchim x Nelore (CN), Angus x Nelore (AN) e Simental x Nelore (SN), nascidas no ano de 1998, provenientes de um mesmo rebanho Nelore formado no início do projeto.

O estudo teve como objetivo estimar as exigências e a eficiência energética de fêmeas adultas lactantes e não gestantes de alguns genótipos utilizados na bovinocultura de corte nacional. No delineamento procurou-se atender as exigências de mantença e lactação de cada indivíduo. Outros objetivos incluem o estudo da composição corporal dos bezerros (necessária para análise dos dados de experimentos de crescimento pósdesmama), avaliação da produção e composição do leite. São dados de extrema importância em função do Brasil manter o maior rebanho comercial de vacas de corte do mundo e da virtual inexistência de resultados de pesquisa comparativa sobre as exigências de fêmeas Nelore e de seus cruzamentos.

As hipóteses consideradas foram:

- $\quad$ A vaca Nelore apresenta menor exigência de energia metabolizável;

- $\quad$ Fêmeas $1 \frac{1}{2}$ Canchim, Angus e Simental têm diferentes exigências;

- Há correlação entre peso adulto e produção de leite com as exigências de mantença e as exigências totais da vaca;

- $\quad$ A eficiência alimentar e energética do par vaca/bezerro é distinta entre a raça pura e os diferentes grupos genéticos. 


\section{REVISÃO DE LITERATURA}

\subsection{Exigência energética}

A exigência energética animal compreende não só as exigências para manutenção, mas também para produção, incluindo crescimento, terminação, prenhez e lactação (Webster, 1979). A eficiência com que os animais ruminantes utilizam a energia dos alimentos é baixa e dependente da quantidade de perdas nas fezes e com a produção de calor. Esta apresenta correlação positiva com o tamanho corporal, a ingestão de matéria seca (IMS), a atividade física, a termorregulação e a deposição de proteína e gordura.

A energia digestível (ED) varia com a natureza física e química do alimento, sendo descontada as perdas fecais. Entre a ED e a energia metabolizável (EM) estão as frações perdidas na urina e na fermentação microbiana, principalmente pela produção de metano. Para a maioria das misturas de forragens com grãos de cereais, a relação entre EM e ED é da ordem de 0,82 (NRC, 1996). Em dietas de terminação esta relação tende a ser maior, já que a proporção de forragem em relação à quantidade de grãos diminui (Webster, 1979). O termo EM é definido como a energia disponível para produção de calor e deposição de tecido corporal (energia retida, $E_{R}$ ) e/ou para lactação, produção de ovos, de lã, etc. Sendo assim, a mantença é estabelecida quando a “ $E_{R}=0$ ” (NRC, 1996) e toda EM ingerida pelo animal for convertida a calor.

De acordo com o ARC (1965), a eficiência líquida de utilização da EM para mantença, ganho de peso e lactação é descrita por coeficientes $k_{m}, k_{g}$, $k_{l}$, respectivamente, que descrevem a eficiência com que a energia metabolizável ingerida (IEM) é utilizada para suprir a exigência de mantença, a deposição de tecido corporal e a 
síntese e secreção de leite durante a lactação. Os coeficientes são fornecidos a partir da publicação do NRC (1976) e foram baseados em estudos de gravidade específica em bovinos em crescimento, a partir de estudos calorimétricos e de abates comparativos (ARC, 1965; 1980, Lofgreen, 1965 e Lofgreen \& Garrett, 1968).

\subsubsection{Variação da composição corporal e da demanda por nutrientes}

Mudanças progressivas no tamanho corporal e composição influenciam a demanda de nutrientes. De acordo com Black (1988) os diferentes tecidos, nervoso, ósseo e muscular desenvolvem-se com taxas de crescimento distintas. A proporção dos ossos no peso corporal decresce com o atingir da maturidade, enquanto a proporção de tecido adiposo tende a aumentar progressivamente e a de proteína permanecer praticamente constante em um organismo adulto, da ordem de 75 a $80 \%$ com base na matéria seca desengordurada.

Fatores como, espécie, raça, sexo, linha de seleção e ingestão influenciam a taxa de crescimento e idade com que um animal atinge o peso adulto e, conseqüentemente, existe variação na partição de nutrientes entre os períodos de deposição de proteína e de tecido adiposo. O aumento da deposição de gordura e decréscimo da proporção de tecido magro, geralmente ocorre quando o animal atinge o tamanho adulto (Lister et al., 1983).

\subsubsection{Fatores que afetam a exigência energética de mantença}

A exigência de energia para mantença representa uma fração substancial da exigência energética de todo sistema de produção (Reynolds, 2002). A quantidade de energia requerida pelo animal para que mantenha o peso vivo constante é tradicionalmente definida como exigência de mantença (Crooker et al., 1991), sendo equivalente à fração total de EM “perdida” na forma de calor (Reynolds, 2002). Entretanto, o peso pode se manter constante mesmo ocorrendo mudanças consideráveis na composição corporal, alterando a quantidade de energia depositada na forma de tecidos. Sendo assim, a definição mais precisa para exigência de mantença é a 
quantidade de energia dietética requerida pelo animal para que este mantenha a quantidade de energia corporal constante, sem deposição ou mobilização de tecidos (NRC, 1984).

A produção total de calor é o somatório de incremento calórico e energia líquida de mantença $\left(E L_{m}\right)$. Esta inclui o metabolismo basal, a termorregulação, a contração muscular e as funções associadas com a relação de síntese e degradação protéica. A exigência de mantença de um animal durante a idade adulta varia de acordo com as mudanças de estado fisiológico e, assim, considerou-se conveniente separar exigência líquida de mantença e de produção (NRC, 1984). A exigência de EL $\mathrm{m}_{\mathrm{m}}$ é por definição a quantidade de energia requerida para produção de calor no estado de jejum, sendo equivalente a $77 \mathrm{kcal} / \mathrm{kg} \mathrm{P}^{0,75}$ (Lofgreen \& Garrett, 1968), valor este, adotado para bovinos de corte de raças britânicas sob condições livres de estresse, em ambiente confinado que permite atividade mínima. Embora seja mais conveniente assumir um valor constante para a exigência energética líquida de mantença, deve-se considerar a necessidade de coeficientes de ajuste, de acordo com a escolha do genótipo e do ambiente a ser explorado. Indivíduos de diferentes raças e de maior tamanho adulto podem apresentar maior requerimento energético, enquanto animais Bos indicus e seus cruzamentos poderiam ser menos exigentes do que o estimado pelo índice de $77 \mathrm{kcal} / \mathrm{kg}$ $\mathrm{P}^{0,75}$ (NRC, 1984), quando nas mesmas condições.

Exemplificando, animais de raças Bos indicus (e.g. Africander, Barzona, Brahman, Sahiwal), durante a fase de crescimento (NRC, 1996), apresentam exigência de mantença $10 \%$ menor do que os animais de raças Bos taurus (e.g. Angus, Hereford, Shortorn, Charolês, Limousin). Mas a variação pode não ser restrita apenas à característica racial. Ferrell \& Jenkins (1984) reportaram que a exigência de EM para mantença de vacas adultas não prenhes e não lactantes variou tanto com o peso adulto, quanto com o potencial de produção de leite. Esses autores, ao compararem vacas Angus x Hereford com cruzamentos Jersey x Angus/Hereford e Simental x Angus/Hereford obtiveram requerimentos de mantença da ordem de 14 e $28 \%$ maiores para esses dois cruzamentos, respectivamente, em relação à exigência de $130 \mathrm{kcal} / \mathrm{kg} \mathrm{P}^{0,75}$ obtida para as vacas Angus x Hereford. 
Solis et al. (1988) avaliaram a exigência de vacas adultas no mesmo estado fisiológico e não verificaram diferença da exigência diária de $\mathrm{EM}\left(\mathrm{kcal} / \mathrm{kg} \mathrm{P}^{0,75}\right)$ nem de eficiência (g/Mcal) entre vacas das raças Brahman e Angus (98 kcal/kg P $\mathrm{P}^{0,75}$ e 135

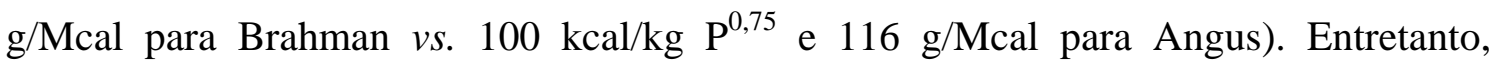
observaram diferença dentro dos grupos genéticos, sendo que quanto maior a ingestão de energia bruta, menor a eficiência em convertê-la a ganho. A semelhança da exigência de mantença dos dois genótipos talvez possa ser explicada pela similaridade das características de peso vivo e de composição corporal. Embora não diferente estatisticamente, a percentagem de gordura no corpo vazio das vacas Angus foi cerca de $20 \%$ maior do que a encontrada para animais da raça Brahman, enquanto a quantidade de tecido magro diferiu entre os dois genótipos em 1\%, sendo este depositado com menor eficiência energética em relação ao tecido adiposo.

\subsubsection{Fatores associados a características do animal e estágio de maturidade}

As exigências de mantença são influenciadas por fatores do animal como atividade física, comprimento do pêlo, espessura da pele e fatores relacionados ao ambiente, que incluem estresse pelo calor ou pelo frio, umidade excessiva, lama, etc. (Crooker et al., 1991). O requerimento de energia relaciona-se às exigências para manutenção, crescimento, gestação e lactação e a necessidade para cada uma dessas funções varia com o tipo de animal.

O efeito da idade é contraditório. Segundo Blaxter et al. (1966) e Graham (1980), a exigência para mantença declina à medida que o animal atinge o tamanho adulto. Enquanto, Taylor et al. (1981) consideram que a exigência de mantença de vacas adultas é a mesma de vacas mais jovens ou em crescimento. De acordo com Breirem \& Homb (1972) citados por Anrique (1976), ao mesmo tempo que os animais durante a fase de crescimento apresentam maior taxa metabólica do que um animal adulto, eles utilizam a energia proveniente da dieta com maior eficiência. 


\subsubsection{Influência da composição corporal sobre a exigência de mantença}

Santos \& Amstalden (1998) consideram que a estimativa do escore de condição corporal (ECC) quantifica o "status” energético da vaca de corte e, a variação desta condição corporal altera a exigência de energia para mantença de vacas adultas. Klosterman et al. (1968) não encontraram diferença para a exigência de mantença entre as raças, mas observaram correlação negativa significativa entre ECC e exigência energética de vacas das raças Hereford e Charolesa, quando alimentadas com quantidades iguais por unidade de peso vivo. As vacas com escore mais baixo perderam peso, enquanto os animais com escore maior apresentaram tendência a ganhar peso. Este resultado pode ser explicado pela maior eficiência energética das vacas com maior ECC, já que estavam mantendo ou depositando tecido adiposo com eficiência de 60 a 80\% (Ferrell, 1988), enquanto os animais mais magros, com baixo ECC, utilizaram a energia consumida para manter ou depositar proteína com eficiência de 10 a 40\% (Ferrell, 1988).

Ferrell \& Jenkins (1985) sugeriram que a variação da condição corporal pode não ser o fator determinante da exigência de mantença, embora muitos estudos tenham ilustrado que o metabolismo basal de ratos e suínos com maior proporção de tecido magro é mais alto do que em animais geneticamente obesos. Anteriormente, Graham et al. (1974) e Dickerson (1978) já haviam observado que o custo de energia para mantença possui maior correlação com o tecido corporal desengordurado, isto é, quantidade de proteína no corpo. No entanto, Vermorel et al. (1976) observaram que animais da raça Charolesa com musculatura simples e dupla apresentaram exigências de mantença semelhantes.

A massa dos órgãos internos tem alta correlação com a exigência de energia, principalmente os órgãos com alta taxa metabólica como fígado e trato gastrintestinal (Truscott et al., 1983 e Ferrell \& Jenkins, 1985), estando direta ou indiretamente associada à elevada taxa de síntese protéica nestes tecidos. Segundo Thompson \& Bell (1976) citados por Ferrell \& Jenkins (1985), o consumo de oxigênio pelo fígado varia de 
15 a 18\% do consumo total de oxigênio em cordeiros de $44 \mathrm{~kg}$ mantidos em ambiente termoneutro.

O músculo esquelético é o maior sítio de armazenamento de proteína, no entanto o gasto energético do processo de síntese e degradação neste tecido está entre 24 e 28\% do total de energia requerida para a síntese e degradação de proteína e é bem menor do que o apresentado pelo somatório dos órgãos viscerais, como já foi descrito por Smith (1970), quando estimou que a soma do gasto energético de tecidos como fígado, trato gastrintestinal e coração é da ordem de 30\%, enquanto pele, cérebro e rins apresentam gasto de cerca de $22 \%$.

Os processos de síntese e degradação protéica são energeticamente dispendiosos e tecidos com alta taxa de reciclagem protéica apresentam alto requerimento de aminoácidos (AA), acentuado fluxo sangüíneo e consumo de oxigênio, reflexo da alta atividade metabólica. Esta é a característica primordial da maioria dos tecidos viscerais como rins, trato gastrintestinal e fígado (Reynolds, 2002). O consumo de oxigênio por estes órgãos é proporcional à IMS, uma vez que os maiores gastos energéticos seriam para atividades como digestão da dieta, absorção e metabolismo de nutrientes, manutenção da estrutura do epitélio intestinal, funções do sistema imune, manutenção da estrutura e das funções celulares pelo transporte de íons e da reciclagem de proteína, energia gasta durante o metabolismo oxidativo de substratos e a síntese de novos compostos (e.g. gluconeogênese hepática).

\subsubsection{Estado fisiológico e potencial de produção}

As exigências de mantença e produção determinam a partição e utilização de nutrientes para processos catabólicos e de síntese, de acordo com a demanda em diferentes órgãos (Reynolds, 2002). Child (1920), citado por Simpfendorfer (1974), mostrou que a partição de nutrientes é determinada pela taxa metabólica dos tecidos, pois tecidos ou órgãos com alta taxa metabólica têm prioridade de suprimento.

Metcalf et al. (1996) suplementaram vacas leiteiras lactantes, utilizando três

níveis de ingestão de uma fonte protéica não degradável no rúmen (PNDR) e 
observaram aumento linear da concentração arterial de AA, mas a resposta em produção de proteína do leite e remoção de AA da corrente sangüínea pelo tecido mamário foi curvilínea, atingindo um platô quando índices intermediários de PNDR foram adicionados à dieta. Os autores concluíram que o suprimento de nutrientes para a glândula mamária é determinado tanto pelo fluxo sangüíneo quanto pela concentração de nutrientes, mas a utilização de AA é determinada pela capacidade de síntese de proteína no tecido mamário.

Neville (1974) observou que vacas Hereford em lactação são mais exigentes do que vacas secas. Reynolds \& Tyrrell (2000) avaliaram dois grupos de novilhas Hereford x Angus, lactantes e não lactantes, durante ensaio calorimétrico em circuito aberto, e encontraram que a produção de calor $/ \mathrm{kg} \mathrm{P}^{0,75}$ foi menor para as novilhas não lactantes do que para as lactantes, que também apresentaram maior IEM, sugerindo que as mudanças metabólicas associadas à lactação aumentam a exigência de mantença.

Alguns trabalhos (Ferrell \& Jenkins, 1984 e 1985; Evans et al., 2001) indicam que vacas com alto potencial de produção de leite requerem mais nutrientes para manter adequada condição corporal e, conseqüentemente, a eficiência reprodutiva. Animais com alto mérito genético para tal característica, geralmente apresentam maior proporção de vísceras, quando comparados a animais caracterizados por baixa produção e com o mesmo tamanho adulto, relacionando-se à maior capacidade de IMS desses animais e também justificando a maior demanda energética mesmo durante o período seco. Jenkins \& Ferrell (1983) verificaram que durante um ciclo completo de produção, o custo energético para uma vaca de $500 \mathrm{~kg}$ produzindo $1.400 \mathrm{~kg}$ de leite durante 205 dias do período de lactação seria de 5.450 Mcal EM/ano, ou seja, 1.400 Mcal EM para lactação (NCR, 1976), 535 Mcal EM para gestação (Ferrell et al. 1976) e 4.825 Mcal EM/ano para manutenção (NCR, 1976).

O aumento da exigência energética de vacas também é observado durante o terço final de gestação e está associado à maior taxa de crescimento e desenvolvimento fetal. Ferrell et al. (1976) não observaram efeitos da prenhez sobre o consumo de oxigênio por órgãos como fígado e rins. No entanto, houve algum indício de aumento da atividade 
metabólica do tecido cardíaco durante a fase final da gestação, sugerindo que o estado gestante pode ter alguma influência sobre a utilização de EM pelo organismo materno.

\subsubsection{Relação genótipo, tamanho adulto e ambiente}

As variações de exigência nutricional dos diferentes grupos genéticos são confirmadas em diversos trabalhos. Manzano et al. (1999), avaliando animais Nelore, Canchim e $1 / 2$ Canchim $+1 / 2$ Nelore, obtiveram menor consumo para animais da raça Nelore, característica associada ao menor potencial de ganho de peso, podendo indicar menores exigências nutricionais em relação aos animais cruzados (Galvão et al., 1991).

Em relação à interação genótipo x ambiente, animais com maior potencial para produção podem ter desvantagens em condições alimentares mais restritivas sendo que a adaptação depende do próprio animal (Jenkins \& Ferrell 1995). Segundo Dickerson (1978) e Evans et al. (2001), cada tipo biológico deve ser avaliado sob condições de produção e manejo que permitam seu desempenho máximo.

Diferenças entre raças para características como tamanho adulto, taxa de crescimento, composição corporal e produção de leite vêm sendo documentadas juntamente com efeitos sobre a exigência energética e eficiência de utilização de energia para mantença e produção. Ferell \& Jenkins (1993) utilizaram vacas adultas Hereford e Simental representando quatro diferentes estados fisiológicos e avaliadas em um ensaio calorimétrico em circuito aberto para mensuração da produção de calor. Observaram que a produção de calor aumentou mais rapidamente e acompanhou o aumento do consumo (g MS/kg PV) nos animais da raça Hereford, chegando a ultrapassar a produção de calor dos animais da raça Simental, quando fornecido alto nível de ingestão, sugerindo que o genótipo com menor potencial de produção de leite é mais adaptado a baixos consumos. Concluíram, portanto, que em condições onde o ambiente não é o fator limitante, genótipos com maior potencial podem ser mais eficientes.

Ferrell \& Jenkins (1985) abordaram que em clima tropical e sob condições de pastejo animais Bos indicus apresentam melhor desempenho do que os de raça Bos taurus. Baker et al. (1973) e Frisch \& Vercoe (1977) avaliaram novilhos em condições 
de consumo ad libitum e observaram que animais de raça britânica apresentaram maior consumo e também maior taxa de ganho de peso do que animais Bos indicus.

O tamanho adulto "ideal” depende do sistema de produção, de forma que uma raça de maior porte pode não ser, necessariamente, desvantajosa (Arango \& Van Vleck, 2002). Animais de menor tamanho adulto atingem mais cedo a puberdade e o peso de abate quando comparados a indivíduos de raças maiores (Dickerson, 1978). Portanto, segundo o NRC (1996), em razão do alto número de informações obtidas utilizando diversas metodologias e condições, a comparação entre os estudos é muito delicada, sugerindo que para a obtenção de dados concretos sobre as exigências nutricionais das inúmeras raças de corte existentes, são necessários mais estudos.

\subsection{Eficiência do sistema}

O termo eficiência biológica foi definido por Dickerson (1978) como o "input" em relação ao "output" total do sistema, sem considerar os custos por unidade de alimento e de produto final, índices estes indispensáveis para a sustentação econômica do sistema de produção. A eficiência, do ponto de vista nutricional, depende de fatores como consumo de alimentos, peso vivo do animal, composição do ganho de peso, condições ambientais, idade e fatores intrínsecos ligados a ela, isto é, taxas de digestão, absorção e utilização de metabólitos.

\subsubsection{Eficiência de produção nas condições tropicais brasileiras}

Sabe-se que no Brasil mais de $80 \%$ do rebanho bovino de corte possui contribuição da raça Nelore, extremamente adaptada às condições tropicais. A superioridade de animais cruzados Bos taurus x Bos indicus em diversos ambientes do Brasil Central em relação aos zebus (Barbosa \& Alencar, 1995) é conseqüência da heterose resultante desses cruzamentos e à complementaridade para determinadas características em relação às raças puras. Dependendo do sistema, dos custos e das raças escolhidas, isto pode representar grande vantagem para a pecuária nacional, uma vez que 
esses animais passam a ter rusticidade e precocidade, com melhor potencial para características desejáveis como tamanho corporal do indivíduo adulto, produção de leite, taxa de crescimento, ganho de peso, precocidade reprodutiva e de acabamento, conversão alimentar, deposição de gordura intramuscular, rendimento de carcaça e outras características de interesse econômico.

A importância da coleta de dados sobre indivíduos cruzados deve-se ao fato de que a utilização de nutrientes e as exigências nutricionais diferem de acordo com cada grupo genético e com os variados níveis de ingestão, como demonstrado por Horn (1967). Nesse experimento com fêmeas de diferentes genótipos, utilizou-se um único índice de ingestão e observou-se, em relação ao sistema em que o alimento não era o fator limitante, queda de 4,8\% na produção total em peso vivo de progênie e 7,7\% na proporção do total de carne produzida, demonstrando a heterogeneidade do grupo quanto às exigências nutricionais.

\subsubsection{Fatores que influenciam a eficiência de produção}

A eficiência biológica de um rebanho de fêmeas é o reflexo do número de bezerros desmamados por unidade de vaca exposta. A eficiência reprodutiva é, neste caso, fundamental e o peso ao desmame é geralmente um fator secundário. No entanto, ao expressar os valores para índices de eficiência econômica, a importância da taxa de crescimento durante o aleitamento torna-se muito relevante (Notter, 2002). De acordo com Armstrong et al. (1990), ao se considerar o peso de desmame como principal parâmetro de eficiência durante a fase de cria, pode-se utilizar o sistema de cruzamento de diferentes raças como ferramenta para introduzir no sistema animais com maior taxa de crescimento pré e pós-desmame o que pode elevar, conseqüentemente, o tamanho adulto e o peso à puberdade, diminuindo a eficiência reprodutiva (Dickerson et al., 1974 e Dickerson, 1978) e aumentando o requerimento de nutrientes (Jenkins et al., 1991). Isto pode ser indesejável ao se considerar que os custos com alimentação equivalem à maior fração do custo total de produção. 
O peso adulto possui alta herdabilidade como afirmam Koots et al. (1994), Barbosa (1991) e Silva et al. (2000), variando de 0,50 a 0,75. Outro fator conhecido é a existência de correlação negativa entre peso adulto e taxa de maturação. Mariante (1978), DeNise et al. (1983), Taylor (1989) e Tedeschi (1996) verificaram que animais com elevado peso adulto apresentam menores taxas de maturação, ou seja, são mais tardios em termos de eficiência reprodutiva e deposição de gordura durante a fase de terminação.

Long et al. (1975) concluíram que vacas de menor tamanho corporal produziram maior quantidade de peso vivo de progênie tanto em sistema de confinamento, quanto a pasto com terminação em confinamento. Recentemente, Euclides Filho \& Figueiredo (2000) relataram que vacas de maior tamanho adulto apresentam maior requerimento nutricional e podem não ser as mais eficientes na produção de quilograma de bezerro desmamado, especialmente nas condições médias encontradas nas regiões tropicais e subtropicais.

Dickerson (1978) afirmou que a característica de tamanho corporal, isoladamente, não é determinante da eficiência econômica total do sistema, apoiando-se no fato de que animais de maior tamanho adulto podem desmamar bezerros mais pesados, com maior taxa de crescimento e maior peso e rendimento de carcaça, minimizando os custos e apresentando melhor relação “output”/”input”, desde que a aplicação do sistema seja em ambiente adequado para maximizar o potencial da raça a ser explorada.

McMoris \& Wilton (1976), assim como Ferrell \& Jenkins (1984) e Jenkins et al. (1991), estudando diferentes grupos genéticos de vacas, concluíram que as de maior tamanho corporal têm maior exigência nutricional (maior IMS) nos períodos seco e de lactação, produzindo filhos mais exigentes que, apesar do maior peso e rendimento de carcaça quando em confinamento, acarretam maiores custos de produção. Verificaram, ainda, que os bezerros de vacas com maior produção de leite consumiam menos ração durante a fase pré-desmame. De acordo com Armstrong et al. (1990), esta observação pode ser o reflexo do potencial de produção de leite e geralmente se observa maior 
consumo de concentrado pelos bezerros, quando as vacas apresentam menor potencial de produção.

Os efeitos negativos do aumento do peso adulto sobre a eficiência do ciclo de produção desaparecem ao diminuir a relação entre requerimento total de alimento e quilograma de produto final, tanto durante a fase de cria quanto na terminação (Dickerson, 1978). O autor aborda, ainda, que o custo relativo por unidade de energia necessária para suprir as exigências das fêmeas no rebanho comparado ao custo durante a terminação pode afetar a relação entre tamanho corporal e eficiência econômica. De acordo com Notter (1977) e Tess \& Davis (2002), o alto custo de um sistema de cria aumenta as vantagens de vacas de menor tamanho adulto sendo utilizadas em cruzamentos terminais com raças de grande porte, produzindo bezerros maiores com maior peso ao desmame e ao abate, mantendo matrizes caracterizadas pela baixa taxa de ingestão.

Jenkins \& Ferrell (1993), avaliando vacas multíparas de diferentes tamanhos e potencial de produção de leite, observaram que aquelas recebendo menores quantidades de alimento desmamaram bezerros mais leves. No entanto, foram mais eficientes na conversão de energia da dieta para quilograma de bezerro, concluindo que raças ou cruzamentos caracterizados por potencial de crescimento e produção de leite intermediários foram mais eficientes durante a fase de aleitamento. A menor exigência das fêmeas relaciona-se positivamente à eficiência total do sistema, provavelmente porque a IMS das vacas é 80 a 85\% do consumo total (Green et al., 1991).

\subsection{Critérios de seleção e eficiência de produção}

A diversidade genética pode ser utilizada para aumentar a eficiência de produção de carne, reduzindo o custo por unidade produzida. A seleção deveria enfatizar não só o aumento do peso adulto e maior rendimento de carcaça, mas também o aumento da produtividade em relação ao peso vivo (Dickerson, 1970). A eficiência de crescimento tem grande importância em bovinos, já que são animais caracterizados pela baixa taxa reprodutiva associada ao alto custo de manutenção do rebanho de fêmeas. 
A eficiência de produção de carne depende tanto dos parâmetros de entrada do sistema quanto da produção e rendimento finais, tendo o melhoramento genético dado pouca ênfase à redução da exigência nutricional com intuito de melhorar a eficiência (Arthur et al., 2001).

Buscam-se oportunidades para reduzir as exigências do rebanho de fêmeas ou melhorar a eficiência de utilização das forragens disponíveis. Para tanto, faz-se necessária a identificação de animais com menor exigência de mantença ou mais adaptados às características do ambiente de produção a ser adotado (Notter, 2002). Archer et al. (1999) hipotetizaram que a seleção para eficiência alimentar poderia ser utilizada para animais em crescimento, apresentando correlação positiva com eficiência alimentar das vacas, assim como a seleção dos animais em ambiente restritivo poderia ser efetiva para aumento da eficiência reprodutiva. Fato que pode ser questionado, já que a maior eficiência alimentar ou menor consumo residual acarreta em diminuição da deposição de gordura interna, podendo ou não diminuir a fertilidade dos animais selecionados para maior eficiência.

Arthur et al. (2001) utilizaram o conceito de seleção para diminuir o consumo residual ("residual feed intake"), que representa a ingestão observada subtraída do valor predito para manutenção e produção, sendo assim, quanto mais negativo o valor do consumo residual, menos exigente é o animal. A seleção para menor consumo deve ser concomitante à escolha de animais com taxa de crescimento acelerada, uma vez que a característica de baixo consumo selecionada isoladamente acarretaria em diminuição do tamanho corporal (Johnston, 2002) e baixo rendimento no período de terminação.

Tess \& Davis (2002) associaram a seleção para aumento da taxa de crescimento ao aumento do tamanho adulto, com conseqüente acréscimo dos custos de mantença, aumento da idade à puberdade e do comprimento do período gestacional. Frisch \& Vercoe (1982) observaram que a seleção para maior taxa de crescimento em ambiente restritivo (condições sub ótimas de alimentação), predispondo a uma situação desafiadora, resulta em decréscimo da produção de calor e diminuição da exigência de mantença e, inversamente, a seleção para taxa de crescimento em ambiente favorável 
(alta disponibilidade de alimento) poderia resultar em aumento do tamanho adulto e, conseqüentemente, aumento das exigências.

Muitos programas de seleção visam o aumento do rendimento de carcaça, com maior deposição de tecido magro o que leva, conseqüentemente, ao aumento das exigências de mantença, já que a deposição de proteína é um processo menos eficiente energeticamente. $\mathrm{O}$ ideal seria que o aumento da taxa de crescimento fosse acompanhado pela característica de precocidade sexual e de acabamento, minimizando as desvantagens do maior tamanho adulto (Dickerson, 1970).

Muitos trabalhos vêm sendo conduzidos dividindo as linhas de seleção em linhagem de "baixa eficiência” e "alta eficiência”, a partir das mensurações individuais de consumo. O índice mais comum de eficiência é a taxa de conversão alimentar (IMS/ganho), medida inversa à eficiência de crescimento (Johnston, 2002). Entretanto, não se trata de um índice de alta confiabilidade, visto que animais com valores idênticos de conversão alimentar apresentam diferentes taxas de crescimento e o baixo potencial para esta característica não seria desejável. Herring \& Bertrand (2002) observaram animais com baixa, média e alta taxa de crescimento (1,800; 1,350 e 0,900 kg de ganho diário) e todos apresentaram conversão alimentar de 5,5 kg MS/kg de ganho.

A estimativa de herdabilidade para conversão alimentar e consumo residual, de acordo com trabalho utilizando animais das raças Angus e Charolesa realizado por Arthur et al. (2001), é da ordem de 0,30 e 0,39, respectivamente, enquanto Herd \& Bishop (2000) reportaram herdabilidades menores $(0,17$ e 0,16) em touros Hereford. Em casos de média herdabilidade, espera-se que a seleção tanto para baixa taxa de conversão alimentar quanto para menor consumo residual resulte em maior eficiência (Herring \& Bertrand, 2002).

Ao se buscar índices de produção mais vantajosos, torna-se indiscutível a necessidade de se estabelecer as exigências de diferentes raças e cruzamentos e seus desempenhos frente a ambientes diversos. Para tanto, estudos que contribuam com dados individuais de consumo, crescimento e eficiência nas diferentes fases do sistema de produção de carne tendem a esclarecer quais as alternativas para melhor interação genótipo x ambiente x sistema de produção. 


\section{MATERIAL E MÉTODOS}

\subsection{Local}

O ensaio de alimentação deste estudo foi realizado na Embrapa Pecuária Sudeste localizada na cidade de São Carlos, SP. O experimento foi conduzido durante os meses de março a dezembro de 2002, em parceria com a ESALQ/USP e com o IZ/SP. Trata-se de um sub-projeto do projeto temático "Estratégias de Cruzamento, Práticas de Manejo e Biotécnicas para Intensificação Sustentada da Produção de Carne Bovina” iniciado no ano de 1997 e desenvolvido com o apoio da FAPESP.

\subsection{Animais}

O rebanho de matrizes foi formado com base na raça Nelore e sistema rotacional de Canchim e Nelore. A partir do terceiro cruzamento alternaram-se as raças dos touros, utilizando, também, touros da raça Simental e Aberdeen Angus em vacas da raça Nelore e, posteriormente, touros Canchim nas fêmeas $1 / 2$ Simental $+1 / 2$ Nelore, $1 / 2$ Angus + 1/2Nelore e 1/2Canchim +1/2Nelore. O objetivo destes sistemas foi a produção de animais representando tipos biológicos diferentes, o que possibilitaria inferência mais abrangente dos resultados.

Foram utilizados quarenta pares de vaca/bezerro de quatro grupos genéticos distintos. Utilizaram-se 10 vacas Nelore (NE), 10 vacas Canchim x Nelore (CN), 10 vacas Angus x Nelore (AN) e 10 vacas Simental x Nelore (SN), todas nascidas em 1998. Os bezerros das fêmeas cruzadas eram filhos de touros da raça Canchim e os bezerros das fêmeas NE eram filhos de touros da raça Nelore. Após o parto, com 15 a 30 dias de 
lactação, os pares vaca/bezerro foram alocados em baias individuais distribuídos em blocos ao acaso, de acordo com a data do parto, completando desta forma 10 blocos e cada um com quatro pares vaca/bezerro, tendo um representante de cada genótipo. Os pares foram acompanhados até o desmame, aos 180 dias de aleitamento.

Dentre os 10 bezerros do cruzamento AN e NE, o número de machos era quatro e seis, respectivamente. Quanto aos grupos CN e SN a relação era de cinco machos para cinco fêmeas.

\subsubsection{Parcelas perdidas}

Um bezerro da raça Nelore (fêmea) e um bezerro do cruzamento com a raça Simental (macho) morreram pouco antes do desmame, o que impossibilitou a coleta de dados referentes ao peso de desmame, à composição do corpo vazio e aos últimos 20 dias de consumo desses animais. As análises destas variáveis utilizaram nove dados do grupo NE e nove do grupo SN.

\subsection{Instalações}

Foram utilizadas 40 baias com dimensão de aproximadamente $15 \mathrm{~m}^{2}$ cada baia. Os bebedouros foram distribuídos para atender duas baias adjacentes. As baias apresentavam $2 \mathrm{~m}$ de piso cimentado na linha de cocho e toda a instalação foi coberta com telhado de folha de zinco.

O sistema de cochos foi adaptado, evitando que o bezerro tivesse acesso à dieta da vaca e vice-versa, possibilitando o controle individual do consumo diário tanto da vaca quanto do bezerro. 


\subsection{Dieta}

A dieta (Tabela 1) foi peletizada para facilitar a oferta e impedir a seleção de ingredientes no cocho, sendo que pela quantidade consumida a ingestão de energia metabolizável (EM) pudesse ser estimada sem necessidade de analisar as sobras.

O valor de EM da dieta foi estimado em 2,24 Mcal/kg de MS, a partir dos resultados de análises bromatológicas de acordo com a equação de Weiss (Weiss et al., 1992) e considerando o coeficiente de 0,75 para taxa de digestão da fração potencialmente degradável do FDN.

A ração era composta, em base seca, por $50 \%$ de feno (15\% feno de alfafa e $35 \%$ feno de Coastcross) e 50\% de concentrado (Tabela 1). 
Tabela 1. Composição da dieta com base na MS

\begin{tabular}{lc}
\hline Ingredientes & \% da MS \\
\hline Feno de Coastcross & 35 \\
Feno de alfafa & 15 \\
Gérmen de milho & 20 \\
Farelo de milho desengordurado & 10 \\
Melaço de cana-de-açúcar, líquido & 5 \\
Farelo de glúten de milho & 5 \\
Farelo de soja & 3 \\
Farelo de trigo & 3 \\
Calcário calcítico & 0,632 \\
Fosfato bicálcico & 1,60 \\
Uréia pecuária & 0,50 \\
Sal & 0,25 \\
Bicarbonato de sódio & 0,80 \\
Monensina sódica & 0,033 \\
Premix vitamínico* & 0,095 \\
Premix mineral** & 0,090 \\
Nutrientes digestíveis totais, \% MS*** & 64,9 \\
Energia metabolizável, Mcal/kg MS & 2,24 \\
Energia digestível, Mcal/kg MS & 2,85 \\
Proteína bruta, \% MS & 16,1 \\
Proteína degradável no rúmen, \% MS**** & 13,5 \\
\hline Vit A: & \\
\hline
\end{tabular}

*Vit A: 16700 UI; Vit D: 3700 UI/kg MS;

**0,2\% Mg; 0,15\% S; 0,1\% Na; 48 ppm Zn; 110 ppm Fe; 19 ppm Cu; 0,5 ppm Co; 3,11 ppm I;

0,52 ppm Se;

***Weisss et al. (1992);

****Lanna et al. (1999).

\subsection{Manejo e coleta de dados}

Os animais foram arraçoados duas vezes ao dia, às $8 \mathrm{~h}$ e às $16 \mathrm{~h}$. Aos 40 dias de idade, os bezerros passaram a ter acesso à mesma dieta fornecida às vacas, em cocho individual e sem restrição de consumo. A ingestão de matéria seca (IMS), tanto para as 
vacas como para os bezerros, foi monitorada diariamente com coleta e pesagem das sobras.

No início e ao final do experimento, os animais foram submetidos a jejum alimentar e hídrico de 16 horas. Nas pesagens intermediárias a cada 14 dias não foi feito o jejum, sendo que os animais recebiam a última refeição às $16 \mathrm{~h}$ e eram pesados na manhã do dia seguinte às 8 h, antes do acesso à primeira refeição. Durante as pesagens, o ECC das vacas foi avaliado por dois observadores independentes e previamente treinados, mantidos por todo o período experimental. As médias dos valores, juntamente com as variações de peso, foram os parâmetros utilizados para corrigir a quantidade de alimento a ser fornecida no período seguinte, na tentativa de minimizar a variação de peso em toda a fase de aleitamento.

Observou-se grande perda de peso para os primeiros 14 dias do experimento. Como as vacas estavam a pasto e passaram a receber uma dieta peletizada considerou-se que $50 \%$ do peso perdido nos primeiros 14 dias foi representado pelo enchimento do trato gastrintestinal.

As produções de leite foram obtidas pelo método de pesagem do bezerro antes e após a mamada (Cundiff et al., 1974). Os bezerros foram separados das vacas após o arraçoamento da manhã às 8 h e, em seguida, às 15 h e 30 min os pares de vaca/bezerro eram reaproximados e a mamada era permitida para que o leite fosse esgotado. Os bezerros eram novamente separados de suas mães até a manhã do dia seguinte $(8 \mathrm{~h})$, o que propiciou a mensuração da produção de leite equivalente ao período de 16 horas, procedimento repetido após 8 horas (16h), de forma que a produção de 24 horas foi a soma da diferença de peso do bezerro nos dois horários de manejo. Essa metodologia foi realizada aos 52, 66, 94, 122 e 178 dias pós-parto, em média.

A metodologia de ordenha manual foi realizada aos 80 e 150 dias pós-parto e o intervalo em que os bezerros foram separados das mães foi o mesmo utilizado durante os controles leiteiros. As vacas receberam uma dose de $2 \mathrm{ml}$ de ocitocina intravenosa antes de cada ordenha para diminuir o efeito de estresse e favorecer a ejeção do leite. Foi feita uma amostragem/animal/dia, utilizando-se dois terços da alíquota total equivalente à 
ordenha da manhã (16 horas de produção) e um terço equivalente à ordenha da tarde (8 horas de produção).

\subsubsection{Parâmetros utilizados para determinar o consumo de MS e se estimar a mobilização ou retenção de energia corporal}

Inicialmente as exigências líquidas de mantença seguiram as indicações do NRC (1976; 1984 e 1996) de 77 kcal/kg $\mathrm{P}^{0,75}$, utilizando-se coeficientes de ajuste estimados para vacas Brahman, Charolesa, Simental e Angus do Clay Center (Ferrell \& Jenkins, 1984) e estimados a partir de dados para machos Nelore (Boin et al., 1994; Tedeschi et al., 2002), bem como do potencial de produção de leite de cada genótipo: 100 para vacas SN, 97 para AN, 96 para CN e 94 para NE, cujas produções de leite no pico da lactação foram consideradas como sendo 11, 9, 8 e $6 \mathrm{~kg}$ de leite/dia, respectivamente.

O ajuste da quantidade consumida foi feito a cada 14 dias, após a pesagem e avaliação do ECC dos animais. As vacas que apresentavam perda de peso passavam a receber, $15 \%$ a mais da quantidade fornecida no período anterior, já os animais que ganhavam peso passavam a receber $15 \%$ a menos.

O valor sugerido pelo NRC (1989) é de 5,6 Mcal/kg de peso perdido ou ganho. Entretanto, Fox et al. (1992) sugerem que o teor de energia do ganho de peso varia em função do ECC. Vacas com ECC menor do que 5 teriam teor de energia no ganho menor. Em função disto, para os resultados médios de ECC deste experimento foi utilizado o valor 5,2 Mcal/kg peso vazio perdido ou ganho pelas vacas.

Ao considerar que toda energia do tecido mobilizado (EL $\mathrm{mob})$ durante a lactação é utilizada para a secreção de leite foi assumido o coeficiente de 0,82 (Van Soest, 1994) como sendo a constante de eficiência de utilização da EL mob para ELl. A energia total secretada no leite subtraída a ELl referente à mobilização de tecido corporal resultou na $E L_{l}$ a partir da energia metabolizável fornecida pelo alimento e utilizada com eficiência de 0,62 (Van Soest, 1994). A energia líquida depositada como tecido foi estimada também, considerando o valor calórico do ganho com sendo 5,2 kcal/kg de peso vazio e para se estimar a energia metabolizável retida $\left(\mathrm{EM}_{\mathrm{R}}\right)$ a partir da $\mathrm{EM}$ da dieta foi 
assumido o coeficiente de eficiência de 0,75 (Van Soest, 1994), considerando que durante a lactação a energia ingerida para produção é utilizada com maior eficiência.

\subsubsection{Parâmetros utilizados para se determinar a produção e a composição do leite}

As produções totais de leite (PTL) acumuladas durante os primeiros 180 dias de lactação foram obtidas pela equação abaixo (1.1), adaptada de ABCBRH (1986).

1.1PTL $=(C 1 * E 1)+\sum_{i=2}^{n}(((C i+C i-1) / 2) * E i)+C n^{*} E n$

Em que:

PTL: produção total de leite, kg;

C1: quantidade de leite no primeiro controle, kg;

E1: intervalo entre o parto e o primeiro controle, dias;

n: número de controles;

Ci: quantidade de leite em cada controle $(i=2,3, \ldots n), \mathrm{kg}$;

Ei: intervalo entre dois controles consecutivos, dias;

Cn: quantidade de leite no último controle, kg;

En: intervalo do último controle ao desmame, dias.

As quantidades de proteína, gordura e extrato seco total foram obtidas multiplicando-se a PTL pelas respectivas percentagens de proteína, gordura e sólidos totais.

As amostras de leite foram analisadas para os percentuais de gordura, proteína, lactose e sólidos totais mediante leitura de absorção de luz infravermelha, utilizando o equipamento Bentley 2000.

A produção de leite corrigida para $4 \%$ de gordura (LCG) foi estabelecida utilizando-se a equação 1.2, descrita abaixo e apresentada por Gaines (1928).

1.2: $L C G=(0,4 * k g$ de leite/dia $)+(15 * \%$ gordura $)$ 
O conteúdo de energia secretada no leite (EL, Mcal) foi estimado utilizando-se os valores de 9,29; 5,47 e 3,95 Mcal/kg para gordura, proteína e lactose, respectivamente (NRC, 2001). O valor energético do leite, para os bezerros, foi estimado pela relação entre energia bruta e energia metabolizável de 0,93 (NRC, 2001).

\subsubsection{Análises laboratoriais e estimativa do valor nutricional da dieta}

As análises feitas nas amostras de ração incluíram proteína bruta (PB), fibra insolúvel em detergente neutro (FDN), nitrogênio ligado à fração FDN (N-FDN), fibra insolúvel em detergente ácido (FDA), nitrogênio ligado à fração FDA (N-FDA), lignina em ácido sulfúrico, cinzas e extrato etéreo (EE). Não foi utilizado sulfito na solução de FDN. O NDT foi estimado, utilizando a seqüência de equações de Weiss (1.3a, 1.3b, 1.3c, 1.3d; Weiss et al., 1992). Todas as análises foram realizadas no Laboratório de Nutrição e Bromatologia da Embrapa Pecuária do Sudeste (CPPSE), de acordo com as normas da AOAC (1995).

\section{3: $N D T(\%)$}

$$
=d v C N F+d v P B+(d v A G * 2,25)+d v F D N-7
$$

1.3a: Digestibilidade verdadeira dos carboidratos não fibrosos (dvCNF)

$$
=0,98\{100-[(F D N-P B F D N)+P B+E E+M M]\}
$$

1.3b: Digestibilidade verdadeira da $P B$ de alimentos concentrados ( $d v P B)$

$$
=\left\{1-\left[0,4^{*}(P B F D A / P B)\right]\right\} * P B
$$

1.3c: Digestibilidade verdadeira dos ácidos graxos $(d v A G)$

$$
\text { = AG; se } E E<1 d v A G=0
$$

1.3d: Digestibilidade verdadeira do FDN ( $d v F D N)$

$$
=0,75 *[(F D N-P B F D N)-\text { lignina }] *\left\{1-[\text { lignina } /(F D N-P B F D N)]^{0,667}\right\}
$$

Em que:

PBFDN = N-FDN*6,25;

PBFDA = N-FDA*6,25; 
$\mathrm{MM}=$ matéria mineral;

$\mathrm{AG}=\mathrm{EE}-1$.

\subsubsection{Abate experimental e estimativa da composição do corpo vazio}

Os bezerros foram desmamados e abatidos, em média, aos 180 dias de idade. Durante a fase post mortem, na carcaça quente, foram feitas as mensurações de peso, comprimento e profundidade. Foram obtidos os pesos do fígado, rins, coração e gordura renal-inguinal, seguindo a metodologia utilizada por Lanna (1988). Após 24 h de resfriamento, a carcaça foi novamente pesada e, então, retirada uma amostra entre a $9^{\mathrm{a}} \mathrm{e}$ $12^{\mathrm{a}}$ costelas da $1 / 2$ carcaça direita para a mensuração da área de olho de lombo e espessura de gordura subcutânea. Foi então retirado o corte da 9- 10- $11^{\text {a }}$ costelas, conforme a metodologia descrita por Hankins \& Howe (1946), que foi pesado e armazenado em freezer. A amostra congelada foi moída, homogeneizada e retirada uma sub-amostra para liofilização, obtendo-se o teor de água. A partir das amostras liofilizadas foram realizadas as análises para extrato etéreo, proteína bruta e matéria mineral.

Análises:

- Extrato etéreo: método de Soxhlet - extração por 4 horas em éter de petróleo;

- Proteína: LECO FP-528 - determinador de proteína por meio da queima da amostra. O aparelho quantifica a quantidade de gás He e por diferença do total de gases que atravessa o sistema de filtragem fornece a quantidade de $\mathrm{N}$ liberada da amostra, a $\mathrm{PB}=\mathrm{N} * 6,25$;

- Matéria mineral: queima da amostra na mufla à $600^{\circ} \mathrm{C}$ durante 3 horas.

A alta correlação entre a composição química da 9- 10- $11^{\text {a }}$ costelas e o corpo vazio foi experimentalmente demonstrada em diversos trabalhos: Hankins \& Howe (1946), Lanna (1988) e Henrique et al. (2003), entre outros.

Foram utilizadas equações que estimassem a composição de água e extrato etéreo do corpo vazio, de acordo com o percentual de água do corte da costela. Na tentativa de 
se adequar as equações aos genótipos dos bezerros avaliados, optou-se, para os bezerros Nelore, pelas equações de regressão linear (1.4a e 1.4b) obtidas por Lanna et al. (1995) para tourinhos da mesma raça. Enquanto que para os bezerros cruzados foram utilizadas as equações (1.5a e 1.5b) descritas por Henrique et al. (2003) obtidas em animais Santa Gertrudes. Nos dois casos a estimativa da composição de proteína e cinzas do corpo vazio foi feita por diferença, considerando a proporção fixa 80:20 na matéria seca desengordurada para os dois componentes, respectivamente. Os valores absolutos, em quilograma, de proteína e gordura foram multiplicados por 5,5 e 9,45 Mcal $/ \mathrm{kg}$ para se estimar a retenção de energia (Mcal) no corpo vazio, ao desmame.

$$
\begin{aligned}
& \text { 1.4a: \%Água corpo vazio }=0,6574 * \% \text { Água corte }+24,1936\left(\mathrm{R}^{2}=0,92\right) \\
& \text { 1.4b: \%EE corpo vazio }=-0,7968 * \% \text { Água corte }+86,64\left(\mathrm{R}^{2}=0,91\right) \\
& \text { 1.5a: \%Água corpo vazio }=1,1221 * \% \text { Água corte }-6,4839\left(\mathrm{R}^{2}=0,95\right) \\
& \text { 1.5b: \%EE corpo vazio }=-1,157 * \% \text { Água corte }+84,26\left(\mathrm{R}^{2}=0,92\right)
\end{aligned}
$$

As equações 1.4a 1.4b referem-se a dados não publicados.

\subsection{Análise estatística}

Para todos os dados de consumo (MS e EM), exigências de mantença e lactação estimadas, peso vivo, produção e composição do leite, parâmetros de carcaça, composição química das costelas e do corpo vazio e os índices de eficiência do par vaca/bezerro foram realizadas análises de variância pelo método dos quadrados mínimos, utilizando-se o procedimento GLM (SAS, 2000). O nível de significância de 5\% foi utilizado para comparar os resultados entre os grupos genéticos, mas para algumas variáveis foi aceito o nível de 10\% de significância.

Para avaliar a presença ou não de diferença entre os pesos vivos das vacas ao início do experimento e ao desmame foi realizado o procedimento TTEST (SAS, 2000), 
por meio de comparação emparelhada, verificando a probabilidade de que a média da diferença entre as duas pesagens fosse igual a 0 .

Foi realizada análise multivariada, utilizando-se o procedimento GLM (SAS, 2000), para correlacionar as variáveis entre si (média de peso vivo da vaca, produção de leite, IMS e IEM da vaca e do par, ingestão de PB do par, peso de desmame e ganho de peso dos bezerros e eficiência protéica e energética), considerando a hipótese de que exista diferença entre os grupos genéticos.

\subsubsection{Modelo estatístico}

Para o estudo da ingestão de MS e de EM, das exigências de mantença e lactação estimadas, do peso vivo, da produção e composição do leite adotou-se o seguinte modelo estatístico:

$$
Y_{i j k}=\mu+G_{i}+B_{j}+P_{k}+C_{l}+e_{i j k l}
$$

Em que:

$\mathrm{Y}_{\mathrm{ijkl}}=$ é a observação referente à média do peso vivo ou à ingestão de matéria seca, em kg, ou de energia metabolizável, em Mcal, ou às exigências de energia metabolizável para mantença e lactação, em Mcal ou em $\mathrm{kcal} / \mathrm{kg}^{0,75}$, ou à mobilização e retenção de energia, em Mcal ou à produção e composição do leite, em kg, ou à percentagem de gordura, proteína, lactose e sólidos totais, do grupo genético $i$, do bloco $j$, com número de partos $k$ e com ECC da vaca l;

$$
\begin{aligned}
& \mu=\text { média geral; } \\
& \mathrm{G}_{\mathrm{i}}=\text { efeito do grupo genético } i \text {, sendo } i=1,2,3 \text { e } 4 ; \\
& \mathrm{B}_{\mathrm{j}}=\text { efeito de bloco } j \text {, sendo } j=1,2, \ldots, 10 ; \\
& \mathrm{P}_{\mathrm{k}}=\text { efeito do número de partos } k \text {, sendo } k=1 \text { e } 2 ; \\
& \mathrm{C}_{\mathrm{l}}=\text { efeito de escore de condição corporal } l \text {, sendo } l=1,2, \ldots, 9 ; \\
& \mathrm{e}_{\mathrm{ijk} \mathrm{l}}=\text { erro aleatório associado a cada observação } \mathrm{Y}_{\mathrm{ijk}} .
\end{aligned}
$$


Para o estudo da ingestão de alimento pelos bezerros, em kg de MS e Mcal de EM, peso ao nascimento, ao desmame, ganho de peso, parâmetros de carcaça, composição química das costelas e do corpo vazio e os índices de ingestão e eficiência do par vaca/bezerro adotou-se o seguinte modelo estatístico:

$$
Y_{i j k l}=\mu+G_{i}+B_{j}+S_{k}+I_{l}+e_{i j k l}
$$

Em que:

$\mathrm{Y}_{\mathrm{ijkl}}=$ é a observação referente ao peso vivo ao nascimento, ou ao desmame ou ao ganho, ou ao peso de carcaça e do corpo vazio, kg, ou à ingestão de matéria seca, em kg, ou de energia metabolizável, em Mcal, ou às medidas de profundidade e comprimento da carcaça, em cm, ou aos percentuais de composição da carcaça, ou às quantidades de água, gordura, proteína e cinzas, em kg, ou à retenção de energia do corpo vazio, em Mcal de acordo com o grupo genético $i$, bloco $j$, com sexo dos bezerros $k$ e com a interação entre sexo e grupo genético $l$;

$$
\begin{aligned}
& \mu=\text { média geral; } \\
& \mathrm{G}_{\mathrm{i}}=\text { efeito do grupo genético } i \text {, sendo } i=1,2,3 \text { e } 4 ; \\
& \mathrm{B}_{\mathrm{j}}=\text { efeito de bloco } j \text {, sendo } j=1,2, \ldots, 10 ; \\
& \mathrm{S}_{\mathrm{k}}=\text { efeito de sexo do bezerro } k \text {, sendo } k=\text { macho e fêmea; } \\
& \mathrm{I}_{\mathrm{l}}=\text { efeito da interação sexo*grupo genético } m ; \\
& \mathrm{e}_{\mathrm{ijkl}}=\text { erro aleatório associado a cada observação } \mathrm{Y}_{\mathrm{ijklm}} .
\end{aligned}
$$




\section{RESULTADOS E DISCUSSÃO}

\subsection{Peso e escore de condição corporal}

As vacas dos grupos genéticos Nelore e $1 \frac{1}{2}$ Canchim foram mais leves $(\mathrm{P}<0,05)$ quando comparadas às vacas cruzadas Angus e Simental (Tabela 3). Os animais cruzados de raça britânica (AN) não apresentaram menor tamanho adulto do que os cruzados da raça continental (SN), provavelmente função dos touros escolhidos da raça britânica, embora estes touros de maior peso adulto sejam bastante utilizados na prática. Sabe-se que a herdabilidade para peso adulto é alta, variando de 0,50 a 0,75, de acordo com Koots et al. (1994) e Barbosa (1991), respectivamente, isto demonstra a importância da escolha dos touros num programa de cruzamento.

Os escores médios de condição corporal (ECC) variaram entre 4 e 5, sendo que não houve diferença estatística entre os pesos ao início do experimento e ao desmame em todos os genótipos avaliados (Tabela 2), ainda que os dados revelem pequena variação numérica. Deste modo, pode-se afirmar que a IEM foi suficiente para suprir as exigências de mantença e lactação. Como houve alguma variação individual, considerou-se ora a mobilização ora a retenção de energia como descrito no material de métodos para cálculos das exigências. 
Tabela 2. Peso vivo em jejum ( \pm erro padrão) de vacas Nelore e F1 ao início (1530 dias) e ao final (180 dias) da lactação

\begin{tabular}{lccc}
\hline & \multicolumn{2}{c}{ Peso vivo em jejum, kg } & \\
Grupos Genéticos & Inicial & Final & P \\
\hline Nelore & $434,0^{\mathrm{a}} \pm 14,2$ & $417,3^{\mathrm{a}} \pm 13,9$ & 0,84 \\
Canchim x Nelore & $451,2^{\mathrm{b}} \pm 9,9$ & $435,3^{\mathrm{b}} \pm 8,7$ & 0,72 \\
Angus x Nelore & $498,0^{\mathrm{c}} \pm 14,7$ & $476,0^{\mathrm{c}} \pm 12,9$ & 0,70 \\
Simental x Nelore & $518,3^{\mathrm{d}} \pm 10,7$ & $497,8^{\mathrm{d}} \pm 10,3$ & 0,14
\end{tabular}

*letras minúsculas distintas, na mesma linha, representam diferenças estatísticas entre as médias por meio de comparações emparelhadas (procedimento TTEST).

Tabela 3. Peso vivo, peso metabólico e escore de condição corporal de vacas Nelore e F1. Média dos primeiros 15-30 dias aos 180 dias de lactação

\begin{tabular}{lcccccc}
\hline & \multicolumn{5}{c}{ Grupo Genético } \\
Variáveis & Nelore & Canchim x & Angus x & Simental x & Erro & P \\
& & Nelore & Nelore & Nelore & Padrão & 0,05 \\
\hline Peso vivo, Kg & $430^{\mathrm{b}}$ & $449^{\mathrm{b}}$ & $496^{\mathrm{a}}$ & $507^{\mathrm{a}}$ & 12,30 & 0,05 \\
Peso metabólico, $\mathrm{P}^{0,75}$ & $94,3^{\mathrm{b}}$ & $97,4^{\mathrm{b}}$ & $105,1^{\mathrm{a}}$ & $106,8^{\mathrm{a}}$ & 1,97 & 0,05 \\
Escore corporal & $4,7^{\mathrm{b}}$ & $4,8^{\mathrm{ab}}$ & $5,0^{\mathrm{a}}$ & $5,1^{\mathrm{a}}$ & 0,11 & 0,11 \\
\hline
\end{tabular}

*letras minúsculas distintas, na mesma linha, representam diferenças estatísticas entre as médias;

\subsection{Produção e composição do leite}

Foram escolhidas raças distintas para as características de tamanho adulto e potencial de produção de leite. Na Figura 1 é representada a relação entre tamanho corporal e produção de leite dos animais avaliados neste experimento. A média da produção diária por grupo referente aos cinco controles leiteiros foi de 7,8 para SN; 6,5 para AN; 5,7 para CN e 4,7 kg/dia para as vacas NE. 


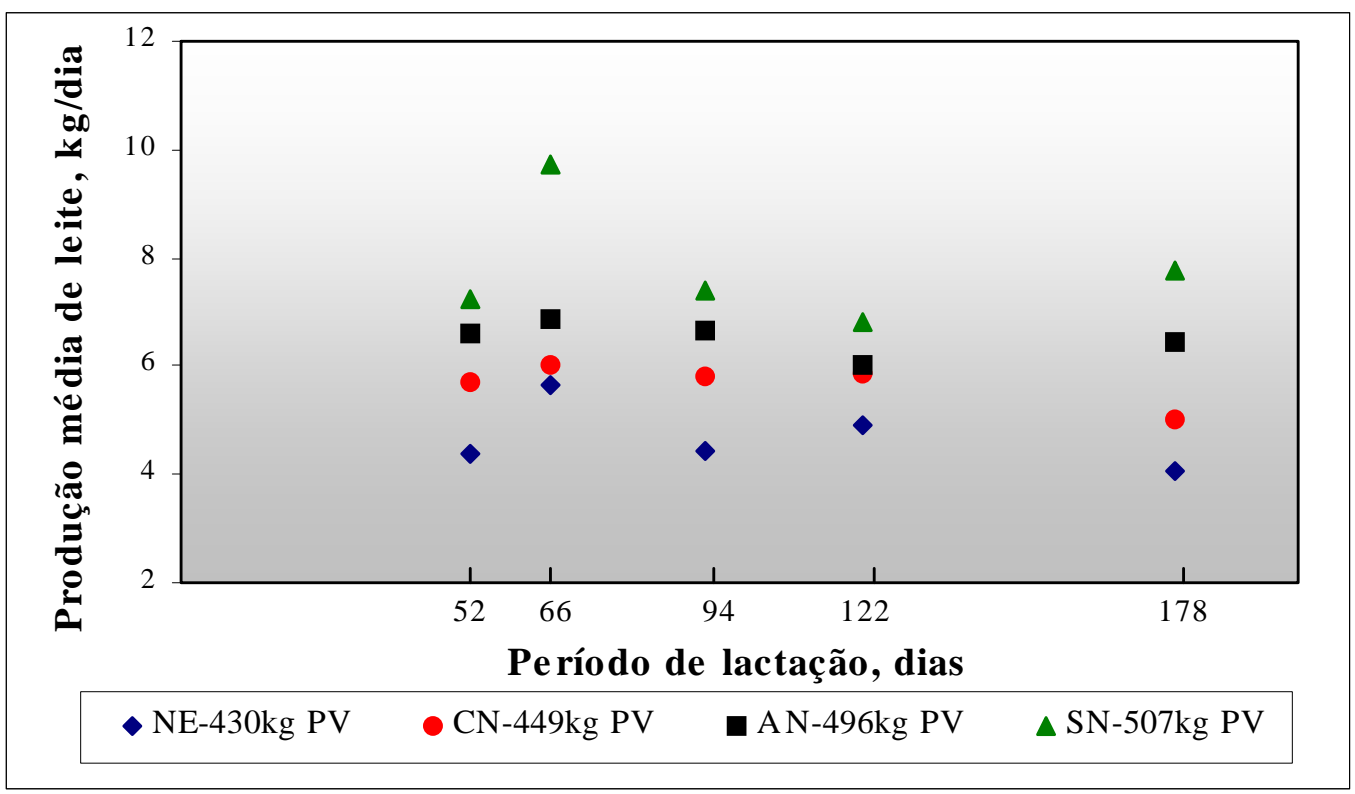

Figura 1 - Produção de leite (kg/dia), ao longo da lactação de vacas Nelore e cruzamentos com Canchim, Angus e Simental

As vacas SN produziram mais leite $(\mathrm{P}<0,05)$ durante a lactação, não diferindo significativamente apenas do genótipo AN (Tabela 4). Quanto à produção de leite corrigida para $4 \%$ de gordura, as vacas $\mathrm{SN}$ mantiveram produções maiores $(\mathrm{P}<0,05)$ que as das vacas da raça NE, enquanto os grupos AN e CN foram intermediários. Alencar et al. (1993) obtiveram valores menores que os encontrados neste experimento para a produção de vacas NE (3,78 kg/dia) e superiores para vacas da raça Canchim (5,87 $\mathrm{kg} / \mathrm{dia}$ ). Pode-se observar que as vacas cruzadas $\mathrm{CN}$, deste estudo, apresentaram produção mais próxima (5,7 kg/dia) da produção das fêmeas puras Canchim avaliadas por Alencar et al. (1993).

Cruz et al. (1997) encontraram produção média de 5,37 e 3,66 kg/dia, para vacas Canchim e Nelore, respectivamente e, neste caso, as vacas da raça Nelore amamentavam bezerros cruzados Canchim x Nelore e, mesmo com o maior potencial de crescimento das crias, os resultados foram menores aos obtidos neste experimento em que as vacas NE aleitavam bezerros Nelore. As diferenças observadas para os grupos genéticos em produção de leite sugerem exigências menores para vacas Nelore que podem ter relevância para definir o potencial de crescimento do bezerro. Mais importante, pode-se 
especular que afetarão decisivamente a eficiência reprodutiva em função da necessidade da vaca garantir maior aporte de energia para que não perca condição corporal.

Tabela 4. Produção total e corrigida para 4\% de gordura e composição média do leite durante o período

\begin{tabular}{lcccccc}
\hline & \multicolumn{5}{c}{ Grupo Genético } \\
Variáveis & Nelore & $\begin{array}{c}\text { Canchim x } \\
\text { Nelore }\end{array}$ & $\begin{array}{c}\text { Angus x } \\
\text { Nelore }\end{array}$ & $\begin{array}{c}\text { Simental x } \\
\text { Nelore }\end{array}$ & $\begin{array}{c}\text { Erro } \\
\text { Padrão }\end{array}$ \\
\hline Produção total de leite, kg & $641,5^{\mathrm{c}}$ & $829,1^{\mathrm{bc}}$ & $969,9^{\mathrm{ab}}$ & $1151,7^{\mathrm{a}}$ & 88,2 & 0,05 \\
Produção de LCG 4\%, kg & $735,5^{\mathrm{b}}$ & $865,5^{\mathrm{ab}}$ & $993,3^{\mathrm{ab}}$ & $1103,8^{\mathrm{a}}$ & 97,6 & 0,05 \\
Gordura, \% & $4,9^{\mathrm{a}}$ & $4,4^{\mathrm{ab}}$ & $4,1^{\mathrm{b}}$ & $3,7^{\mathrm{b}}$ & 0,26 & 0,05 \\
Proteína, \% & $3,7^{\mathrm{a}}$ & $3,5^{\mathrm{ab}}$ & $3,2^{\mathrm{b}}$ & $3,1^{\mathrm{b}}$ & 0,10 & 0,05 \\
Lactose, \% & 4,6 & 4,7 & 4,7 & 4,8 & 0,13 & NS \\
Sólidos totais, \% & $14,4^{\mathrm{a}}$ & $13,7^{\mathrm{ab}}$ & $13,0^{\mathrm{bc}}$ & $12,7^{\mathrm{c}}$ & 0,30 & 0,05 \\
\hline
\end{tabular}

*letras minúsculas distintas, na mesma linha, representam diferenças estatísticas entre as médias.

Para as vacas NE, que apresentaram menor produção de leite, o percentual de gordura foi da ordem de 4,9\% (Tabela 4). Este percentual de gordura foi maior $(\mathrm{P}<0,05)$ do que o encontrado para $\mathrm{AN}$ e $\mathrm{SN}$ (4,1 e 3,7\%, respectivamente). No caso das vacas CN o percentual de gordura não diferiu dos outros genótipos. Estes resultados confirmam aqueles descritos por Cruz et al. (1997), que observaram para vacas da raça Canchim maior produção total de leite, em 238 dias de lactação, em relação às vacas da raça Nelore (1269,0 vs. 883,0 kg) e percentuais de gordura de 4,74 e 5,53\% para Canchim e Nelore, respectivamente. $\mathrm{O}$ maior percentual $(\mathrm{P}<0,05)$ de sólidos totais para as vacas de menor produção de leite, Nelore e CN, sugere a presença de efeito de diluição.

As percentagens de proteína do leite também foram maiores $(\mathrm{P}<0,05)$ para as vacas NE (3,7\%) do que para AN (3,2\%) e para SN (3,1\%). As vacas CN produziram leite com percentual de proteína intermediário (3,5\%), não diferindo dos outros três grupos. Valores semelhantes (3,32\%) para animais cruzados de raças européias foram encontrados por Beal et al. (1990). Entretanto, os resultados revelaram, em valores absolutos, que vacas SN, de maior produção de leite, produziram também maiores 
$(\mathrm{P}<0,05)$ quantidades de proteína do que as vacas $\mathrm{NE}(35,8$ vs. 23,7 kg), semelhante às diferenças encontradas por Cruz et al. (1997) para animais das raças Canchim e Nelore. Por outro lado, a quantidade de gordura produzida não diferiu $(\mathrm{P}>0,05)$ entre os grupos genéticos: 42,9 para $\mathrm{SN}$; 40,4 para $\mathrm{AN}$; 35,6 para $\mathrm{CN}$ e 31,9 para as vacas NE. Entretanto, estas diferenças numéricas são biologicamente e economicamente importantes e sugerem que mais unidades experimentais sejam utilizadas para confirmar tais diferenças.

\subsection{Ingestão de matéria seca}

A IMS se correlacionou positivamente com a produção de leite (Tabela 5 e Tabela19 no item 4.9). As vacas cruzadas $\mathrm{SN}$ apresentaram maior consumo $(\mathrm{P}<0,05)$ do que os outros três grupos genéticos (1651,9; 1541,6; 1466,9 e 1391,6 kg MS para SN, AN, CN e NE, respectivamente). Armstrong et al. (1990) avaliaram vacas de tamanho adulto e potencial de produção de leite distintos e observaram maior IMS para as fêmeas de grande porte do cruzamento das raças Maine-Anjou, Simental e Charolesa em relação ao grupo de pequeno porte, representado por vacas Hereford ou seu cruzamento com Angus, Gelbvieh ou Pinzgauer. Os autores encontraram IMS de 2.298,6 vs. 1.642,0 kg MS durante 200 dias de lactação, respectivamente para os grupos de grande e pequeno porte (694 kg e $579 \mathrm{~kg}$ PV) e a média de produção de leite foi de 7,7 e 4,5 kg/dia, respectivamente.

As vacas NE consumiram menores quantidades de MS $(\mathrm{P}<0,05)$, em percentagem do peso vivo e em relação ao peso metabólico, do que os genótipos AN e SN (Tabela 5), não diferindo ( $\mathrm{P}>0,01)$, das vacas $C N$. Este fato sugere que animais mais pesados e com maior potencial de produção de leite e crescimento caracterizam-se pelo maior consumo, fato que já havia sido mencionado por Jenkins et al. (1991). 
Tabela 5. Peso vivo, produção de leite e ingestão de matéria seca de vacas Nelore e cruzadas

\begin{tabular}{|c|c|c|c|c|c|c|}
\hline \multirow[b]{2}{*}{ Variáveis } & \multirow[b]{2}{*}{ Nelore } & \multicolumn{3}{|c|}{ Grupo Genético } & \multirow[b]{2}{*}{$\begin{array}{c}\text { Erro } \\
\text { Padrão }\end{array}$} & \multirow[b]{2}{*}{$\mathrm{P}$} \\
\hline & & $\begin{array}{c}\text { Canchim x } \\
\text { Nelore }\end{array}$ & $\begin{array}{c}\text { Angus x } \\
\text { Nelore }\end{array}$ & $\begin{array}{c}\text { Simental x } \\
\text { Nelore }\end{array}$ & & \\
\hline Peso vivo, kg & $430^{b}$ & $449^{b}$ & $496^{\mathrm{a}}$ & $507^{\mathrm{a}}$ & 12,3 & 0,05 \\
\hline Produção total de leite, kg & $641,5^{\mathrm{c}}$ & $829,1^{\text {bc }}$ & $969,9^{\mathrm{ab}}$ & $1151,7^{\mathrm{a}}$ & 88,2 & 0,05 \\
\hline IMS total, kg & $1391,6^{\mathrm{c}}$ & $1466,9^{\mathrm{bc}}$ & $1541,6^{\mathrm{b}}$ & $1651,9^{\mathrm{a}}$ & 35,1 & 0,05 \\
\hline IMS, kg/dia & $8,8^{\mathrm{b}}$ & $9,2^{\mathrm{b}}$ & $10,3^{\mathrm{a}}$ & $10,6^{\mathrm{a}}$ & 0,2 & 0,01 \\
\hline IMS, \% PV & $1,99^{\mathrm{b}}$ & $2,15^{\mathrm{a}}$ & $2,21^{\mathrm{a}}$ & $2,23^{\mathrm{a}}$ & 0,04 & 0,05 \\
\hline IMS, g MS/kg P & $91,6^{\mathrm{c}}$ & $97,9^{\mathrm{b}}$ & $102,3^{\mathrm{ab}}$ & $104,5^{\mathrm{a}}$ & 1,8 & 0,05 \\
\hline
\end{tabular}

*letras minúsculas distintas, na mesma linha, representam diferenças estatísticas entre as médias; em que: IMS: ingestão de matéria seca; PV: peso vivo.

Jenkins \& Ferrell (1983) afirmaram que há interação entre raça e IMS para eficiência, parte dessa interação é relacionada ao potencial de produção de leite que, quanto maior, maior a eficiência desses animais quando submetidos à alta disponibilidade de alimento. Nas mesmas situações, animais de menor potencial para produção de leite apresentam aumento mais acelerado da produção de calor, ou seja, são menos eficientes em converter a EM da dieta em energia líquida de produção. Ferrell \& Jenkins (1993) demonstraram que quando a IMS, tanto das vacas Hereford quanto das

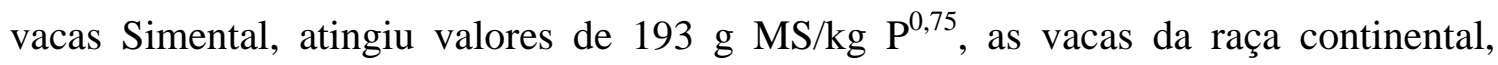
caracterizadas pelo maior tamanho adulto e maior potencial de produção, passaram a ser mais eficientes na conversão de energia ingerida para secreção de leite, produzindo menos calor do que os animais Hereford, adaptados a condições ambientais mais limitantes.

Os resultados de consumo com base na matéria seca tornam-se importantes por serem facilmente convertidos a valores econômicos, passíveis em relatar a viabilidade do sistema de produção. Infelizmente não foi possível avaliar a eficiência em seus parâmetros econômicos e reprodutivos neste experimento. 


\subsection{Exigência de energia metabolizável}

As exigências para a soma das funções de mantença e lactação $\left(E M_{m}\right.$ e $\left.E M_{l}\right)$ foram atendidas, ou seja, os valores de PV em jejum ao início e ao final do período apresentaram pequena variação (Tabela 2) para cada um dos genótipos avaliados. A IEM foi maior ( $\mathrm{P}<0,05$; Tabela 6) para as vacas SN (3701,9 Mcal) em relação aos animais NE (3118,4 Mcal) e CN (3287,2 Mcal), a ingestão deste grupo não diferiu da apresentada pelas vacas AN (3454,5 Mcal). Considerando a IEM em $\mathrm{kca} / \mathrm{kg} \mathrm{P}^{0,75}$, pode-se observar na Figura 2 a comparação entre os grupos genéticos.

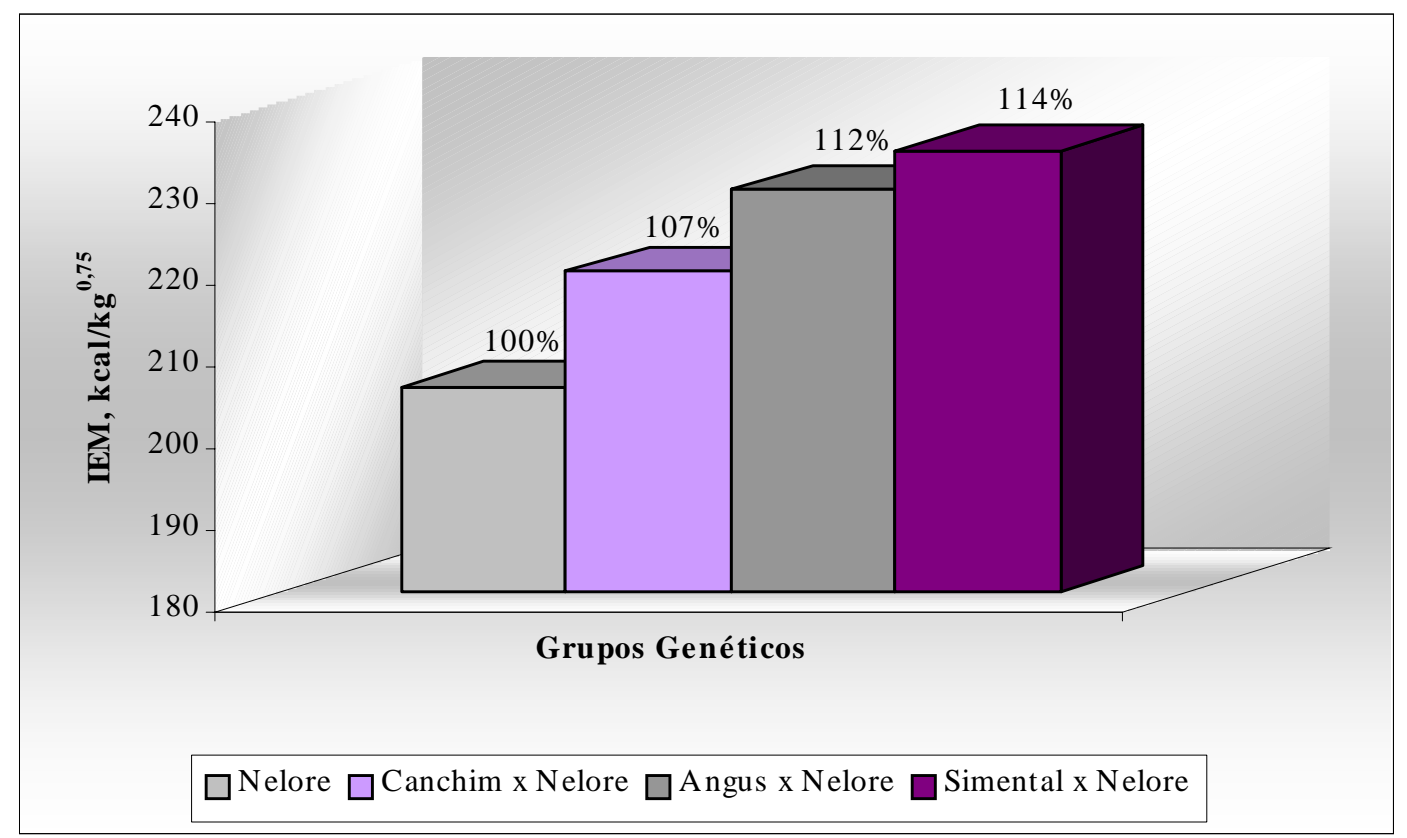

Figura 2 - Variação da IEM (kcal/kg $\left.\mathrm{P}^{0,75}\right)$ entre as vacas Nelore e cruzadas Canchim, Angus e Simental

Ferrell \& Jenkins (1984), Montaño-Bermudez et al. (1990) e Jenkins et al. (1991) indicaram que a IEM diária necessária para equilíbrio do PV foi maior para os animais de alto peso adulto e maior potencial de produção de leite, assim como o encontrado neste experimento. As vacas NE consumiram menores ( $<<0,01$; Tabela 6) quantidades diárias de EM dentre todos genótipos; 19,7 para NE; 20,6 para CN; 23,1 para AN e 23,7 Mcal/dia para SN, sendo o consumo dos dois últimos grupos iguais estatisticamente. Da 
mesma forma, Green et al. (1990) encontraram valores de 27,7 e 24,1 Mcal/dia de IEM para os cruzamentos Brahman x Angus ou Brahman x Hereford em relação ao grupo Angus x Hereford, sendo este, caracterizado pelo menor peso e potencial de produção (582 vs. 548 kg de PV e 928,4 vs. 802,3 kg de leite, respectivamente). Corroborando esta afirmação, Jenkins et al. (1991) observaram valores de 26,5; 26,9 e 29,1 Mcal EM/dia para animais cruzados Red Poll, Angus x Hereford e para o cruzamento com a raça Pardo-Suíço, de maior peso e potencial de produção de leite.

Os resultados obtidos para exigência de energia metabolizável para mantença $\left(\mathrm{EM}_{\mathrm{m}}\right)$ não revelam diferença ( $\mathrm{P}>0,05$; Tabela 6). Embora não significativa, os animais Nelore apresentaram exigências cerca de 6\% menores por peso metabólico em relação aos animais cruzados B. taurus. Uma vez que todos os animais apresentam cerca de $50 \%$ de sangue Nelore, as diferenças de $6 \%$ são bastante semelhantes às sugeridas pelo NRC (1996) de cerca de 10\% para zebuínos em relação aos taurinos. A magnitude da diferença é consistente com os resultados dos trabalhos conduzidos por Cal Ferrell e colaboradores.

Tabela 6. Médias ( \pm erro padrão) de IEM e das exigências de EM para mantença e lactação de vacas Nelore e F1

\begin{tabular}{|c|c|c|c|c|c|}
\hline \multirow[b]{2}{*}{ Variáveis } & \multicolumn{4}{|c|}{ Grupo Genético } & \multirow[b]{2}{*}{$\mathrm{P}$} \\
\hline & Nelore & $\begin{array}{c}\text { Canchim x } \\
\text { Nelore }\end{array}$ & Angus x Nelore & $\begin{array}{c}\text { Simental x } \\
\text { Nelore }\end{array}$ & \\
\hline Peso metabólico, $\mathrm{P}^{0,75}$ & $94,3^{\mathrm{b}} \pm 1,97$ & $97,4^{\mathrm{b}} \pm 1,97$ & $105,1^{\mathrm{a}} \pm 1,97$ & $106,8^{\mathrm{a}} \pm 1,97$ & 0,01 \\
\hline IEM, Mcal & $3118,4^{\mathrm{C}} \pm 78,6$ & $3287,3^{\mathrm{bc}} \pm 78,6$ & $3454,5^{b} \pm 78,6$ & $3701,9^{a} \pm 78,6$ & 0,05 \\
\hline IEM, Mcal/dia & $19,7^{\mathrm{b}} \pm 0,43$ & $20,6^{\mathrm{b}} \pm 0,50$ & $23,1^{\mathrm{a}} \pm 0,46$ & $23,7^{\mathrm{a}} \pm 0,50$ & 0,01 \\
\hline IEM, kcal EM/kg P $\mathrm{P}^{0,75} /$ dia & $205,3^{\mathrm{c}} \pm 3,7$ & $219,3^{\mathrm{b}} \pm 4,4$ & $229,3^{\mathrm{ab}} \pm 4,0$ & $234,3^{a} \pm 4,3$ & 0,05 \\
\hline $\mathrm{EM}_{\mathrm{m}}$, kcal EM/kg P $\mathrm{P}^{0,75} / \mathrm{dia}$ & $141,3 \pm 6,6$ & $149,7 \pm 7,8$ & $152,4 \pm 7,2$ & $147,2 \pm 7,7$ & NS \\
\hline $\mathrm{EM}_{\mathrm{l}}$, kcal EM/kg P $\mathrm{P}^{0,75} / \mathrm{dia}$ & $64,2^{\mathrm{b}} \pm 6,9$ & $69,2^{\mathrm{a}} \pm 8,3$ & $76,4^{\mathrm{a}} \pm 7,6$ & $83,2^{\mathrm{a}} \pm 8,1$ & 0,10 \\
\hline
\end{tabular}

*letras minúsculas distintas, na mesma linha, representam diferenças estatísticas entre as médias;

em que: IEM: ingestão de energia metabolizável; $\mathrm{EM}_{\mathrm{m}}$ : exigência de energia metabolizável de mantença; $\mathrm{EM}_{\mathrm{l}}$ : exigência de energia metabolizável de lactação. 
Montaño-Bermudez \& Nielsen (1990) avaliaram fêmeas F1 de mesmo tamanho adulto e diferentes quanto ao potencial de produção de leite (alta, moderada e baixa produção) e observaram maior exigência energética, da ordem de $10 \%$ tanto para lactação quanto para mantença das vacas de moderado potencial de produção, em relação às de baixa produção, que quando comparadas ao grupo de alto potencial apresentaram exigências menores em 12\% para lactação e 7\% para mantença.

Os resultados obtidos revelaram que as vacas $\mathrm{SN}$ se caracterizaram pela maior produção de leite e, conseqüentemente, utilizaram maior fração da ingestão diária de EM para lactação, com maior diferença $(\mathrm{P}<0,10)$ entre os grupos $\mathrm{SN}$ e NE; 83,2 vs. 64,5 $\mathrm{kcal} / \mathrm{kg} \mathrm{P}^{0,75} /$ dia $\mathrm{EM}_{\mathrm{l}}$, respectivamente (Tabela 6). As proporções de $\mathrm{EM}_{\mathrm{m}}$ e $\mathrm{EM}_{\mathrm{l}}$ ilustradas na Figura 3 demonstram que os grupos com maior produção de leite utilizaram maior fração da EM da dieta para a secreção de energia no leite (ELl), conseqüentemente, menor fração da energia ingerida foi utilizada para as funções de mantença. Portanto não se pode afirmar, neste caso, que as vacas com maior “input” foram menos eficientes, já que o maior consumo e a maior secreção de energia no leite estão relacionados ao mesmo grupo genético. 

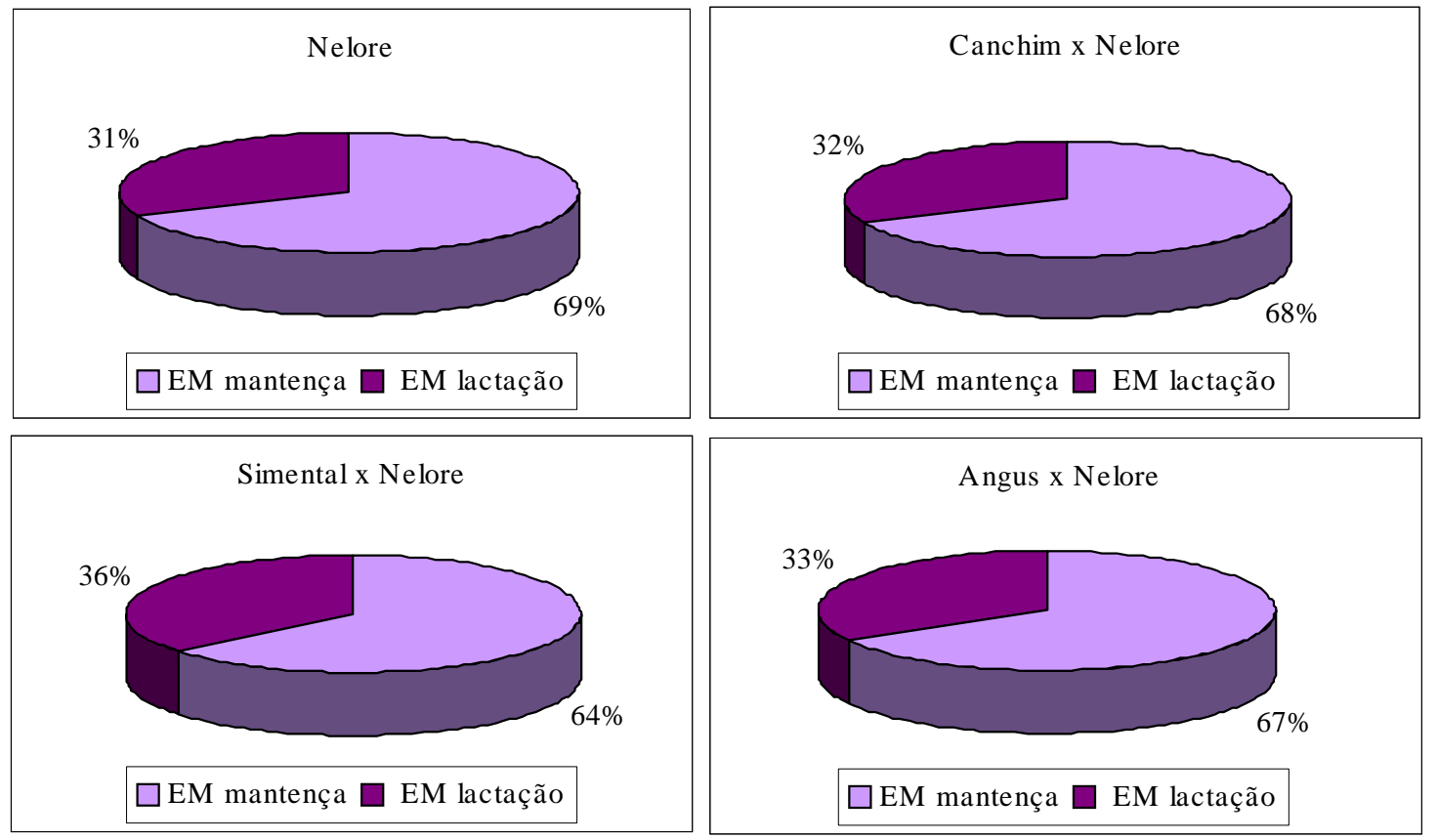

Figura 3 - Partição da energia metabolizável para mantença e lactação, em quatro grupos genéticos de vacas lactantes e não gestantes

De acordo com Reid (1970) o percentual da EM ingerida utilizado para mantença é menor, quanto maior a produção de leite. Os grupos avaliados não foram submetidos à limitação de alimento capaz de interferir no desempenho dos animais mais exigentes e demonstrar, como o esperado em uma das hipóteses, que as vacas Nelore se mostrassem mais eficientes do que os genótipos cruzados ao produzirem menos calor, fato que de acordo com alguns autores (Jenkins et al., 1986 e Hotovy et al., 1991) relaciona-se à redução da exigência de mantença.

Em condições desafiadoras de pastejo, animais Bos indicus tendem a apresentar menores perdas de peso do que os Bos taurus (Frisch, 1973), e em ambiente semelhante de restrição (Moran, 1976), novilhos 3/4 Brahman apresentam menor IMS com desempenho equivalente aos animais da raça Hereford. Já em condições de consumo ad libitum, Baker et al. (1973) e Frisch \& Vercoe (1977) citados em 1985 por Ferrell \& Jenkins, observaram que novilhos de raça britânica apresentam maior consumo e também maior taxa de ganho de peso do que animais Bos indicus. É de se esperar que as 
vacas Nelore não expressaram sua capacidade de reduzir a produção de calor em função do alto nível nutricional a que foram submetidas.

A menor exigência de mantença para animais Bos indicus também foi hipotetizada por Solis et al. (1988), que não obtiveram diferença na exigência de mantença entre animais puros de raças Bos indicus e Bos taurus, no entanto os resultados encontrados por esses autores parecem demonstrar que o cruzamento entre as duas raças aumenta a exigência energética de mantença em relação às raças puras (100,0 para Angus; 98,0 para Brahman vs. 102,0 kcal $/ \mathrm{kg} \mathrm{P}^{0,75}$ para o cruzamento Angus x Brahman). Os valores mais elevados para $\mathrm{EM}_{\mathrm{m}}$ das vacas deste experimento (141,3; 149,7; 152,4; 147,2 kcal/kg $\mathrm{P}^{0,75}$ para NE, CN, AN e SN, respectivamente) deve-se ao fato de que os animais do trabalho acima foram avaliados durante a fase não gestante e não lactante. Diversos autores (Neville, 1974 e Reynolds \& Tyrrell, 2000) demonstraram que vacas em fase de lactação apresentam maior exigência de mantença.

Taylor et al. (1986) concluíram que a variação genética para eficiência de mantença correlaciona-se negativamente com as diferenças para incremento calórico, ou seja, IMS, propondo que há variação para produção de calor entre ambientes distintos. Jenkins et al. (1986) relataram a existência de variabilidade genética para massa dos órgãos internos, geralmente mais abundante em genótipos de aptidão leiteira e de maior tamanho adulto (mais exigentes), e como a fração de vísceras é a maior contribuidora para a variação do metabolismo basal os autores defenderam a variabilidade da produção de calor entre raças. Ao se associar as duas linhas de pensamento, pode-se dizer que à medida que o ambiente é melhorado, aumentando-se a ingestão, os animais de maior potencial de crescimento e produção (cruzamentos Bos taurus) tendem a tornar-se mais competitivos ou mesmo mais eficientes biológica e economicamente do que animais puros de menor potencial de crescimento e menor produção de leite. É necessário ter conhecimento da exigência de mantença da raça escolhida, para criar condições capazes de suprir sua demanda de manutenção e produção.

Embora os valores de PV em jejum ao início e ao final do experimento sejam iguais estatisticamente, houve mobilização e retenção de energia no transcorrer da lactação, que foram estimadas considerando a oscilação do ECC entre 4 e 5 . Na Figura 4 
estão ilustrados graficamente os valores de $E_{m}$ e $E M_{l}$, já associados à energia mobilizada na forma de tecidos, que não diferiu $(\mathrm{P}>0,05)$ entre os genótipos (Tabela 7$)$.

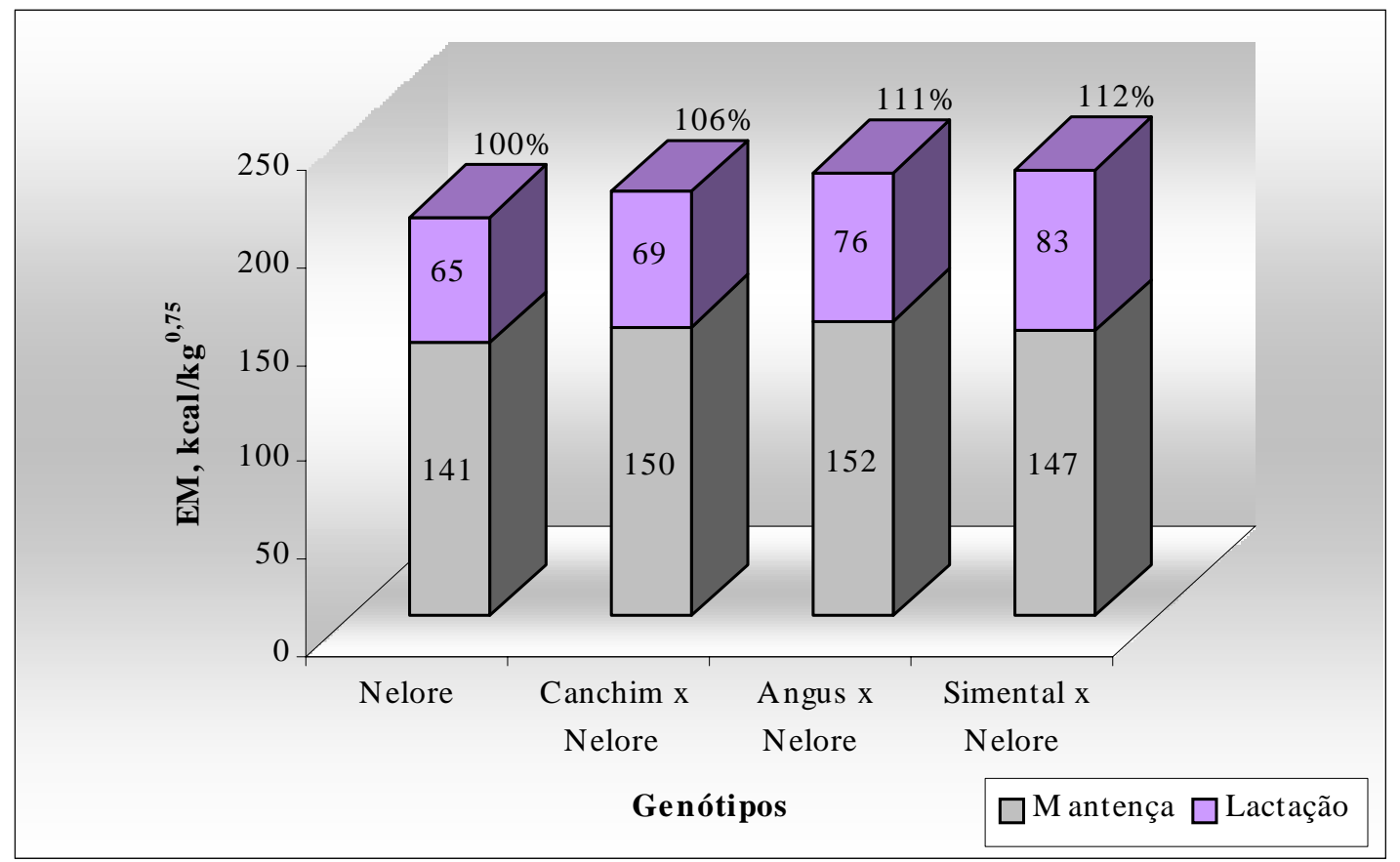

Figura 4 - Estimativas das exigências de mantença e lactação de vacas Nelore e F1 e a variação entre os genótipos

Tabela 7. Energia líquida e metabolizável mobilizada e a relação com o peso metabólico para vacas lactantes da raça Nelore e cruzadas

\begin{tabular}{|c|c|c|c|c|c|}
\hline \multirow[b]{2}{*}{ Variáveis } & \multicolumn{5}{|c|}{ Grupo Genético } \\
\hline & Nelore & $\begin{array}{l}\text { Canchim x } \\
\text { Nelore }\end{array}$ & $\begin{array}{l}\text { Angus x } \\
\text { Nelore }\end{array}$ & $\begin{array}{c}\text { Simental x } \\
\text { Nelore }\end{array}$ & $\mathrm{P}$ \\
\hline $\mathrm{EL}_{\mathrm{mob}}$, Mcal EM, 180 dias & $123,8 \pm 39,7$ & $102,0 \pm 47,2$ & $182,9 \pm 43,1$ & $98,9 \pm 46,2$ & NS \\
\hline EL $_{\text {mob }}$, Mcal EM/dia & $0,77 \pm 0,25$ & $0,64 \pm 0,30$ & $1,20 \pm 0,27$ & $0,62 \pm 0,29$ & NS \\
\hline $\mathrm{EM}_{\text {mob }}$, Mcal EM/kg P $\mathrm{P}^{0,75}$ & $1,26 \pm 0,38$ & $1,11 \pm 0,45$ & $1,81 \pm 0,41$ & $1,02 \pm 0,44$ & NS \\
\hline
\end{tabular}

*Não houve diferença estatística $(\mathrm{P}>0,05)$ entre as médias apresentadas na mesma linha. 


\subsection{Desempenho dos bezerros: índices de ingestão e eficiência}

Os bezerros da raça Nelore apresentaram menor $(\mathrm{P}<0,05)$ peso ao nascimento (Tabela 8). Como esperado, os cruzamentos $\mathrm{CN}$, AN e SN, com maior potencial de crescimento, apresentaram maior peso ao desmame (Tabela 8). Estes resultados coincidem com a escala observada por Jenkins \& Ferrell (1993) entre os genótipos Bos taurus e seus cruzamentos. Os bezerros puros de fêmeas NE apresentaram menor peso de desmame $(\mathrm{P}<0,05)$ do que os bezerros $3 / 4 \mathrm{C}^{1} / 4 \mathrm{~N}, 1 / 2 \mathrm{C}^{1} / 4 \mathrm{~A} 1 / 4 \mathrm{~N}$ e $1 / 2 \mathrm{C} 1 / 4 \mathrm{~S} 1 / 4 \mathrm{~N}(167,3$ vs. 205,5, 220,0 e 228,1 kg de PV, respectivamente).

Associado ao menor ganho de peso durante o aleitamento (Tabela 8), os bezerros da raça Nelore apresentaram menor $(\mathrm{P}<0,05)$ IMS (kg MS de leite + kg MS de ração). Para o consumo de ração, a maior diferença numérica foi observada entre os animais $3 / 4 \mathrm{C}^{1} / 4 \mathrm{~N}$ e Nelore, com valores 147,5 e 116,7 $\mathrm{kg}$ MS, respectivamente. O consumo de leite, em MS, foi inferior $(\mathrm{P}<0,01)$ para os bezerros puros Bos indicus (Tabela 8).

De acordo com Armstrong et al. (1990), a menor IMS de ração pelos bezerros relaciona-se à maior produção de leite da mãe, algo que não foi confirmado neste experimento. Os bezerros da raça Nelore não consumiram maior quantidade de MS de ração mesmo apresentando menor ingestão de leite. Assim, não se pode afirmar que o menor ganho de peso dos animais desse grupo esteja associado, somente, ao menor potencial de produção de leite das vacas (Tabela 5; $\mathrm{P}<0,05$ ). Mas pode refletir a menor taxa potencial de crescimento dos animais Nelore (Lanna et al., 1996 citado no NRC, 1996). Entretanto, os bezerros $3 / 4 C^{1} / 4 \mathrm{~N}$ consumiram, em média, $16 \%$ mais ração do que os bezerros cruzados dos grupos AN e SN, que ingeriram 10 e 24\% mais leite (kg MS), indicando que para suprir a alta taxa de crescimento dos bezerros $3 / 4 \mathrm{C} 1 / 4 \mathrm{~N}$ a menor produção de leite das vacas é compensada pelo maior consumo de ração. 
Tabela 8. Médias ( \pm erro padrão) de pesos ao nascimento e ao desmame, IMS e alguns parâmetros de desempenho de bezerros Nelore, 3/4 $\mathrm{C}^{1 / 4} \mathrm{~N}, 1 / 2 \mathrm{C}^{1} / 4 \mathrm{~A} 1 / 4 \mathrm{~N}$ e $1 / 2 \mathrm{C}^{1 / 4} \mathrm{~S} 1 / 4 \mathrm{~N}$

Grupo Genético

\begin{tabular}{|c|c|c|c|c|c|}
\hline Variáveis & Nelore & $3 / 4 \mathrm{C}^{1} / 4 \mathrm{~N}$ & $1 / 2 \mathrm{C}^{1 / 4} \mathrm{~A}^{1} 1 / 4 \mathrm{~N}$ & $1 / 2 \mathrm{C}^{1 / 4} \mathrm{~S}^{1 / 4} \mathrm{~N}$ & $\mathrm{P}$ \\
\hline Peso vivo ao nascimento, $\mathrm{kg}$ & $29,8^{\mathrm{C}} \pm 2,1$ & $38,4^{\mathrm{ab}} \pm 1,8$ & $36,5^{\mathrm{b}} \pm 1,8$ & $44,1^{\mathrm{a}} \pm 1,9$ & 0,05 \\
\hline Peso vivo ao desmame, $\mathrm{kg}$ & $167,3^{\mathrm{b}} \pm 11,9$ & $205,5^{\mathrm{a}} \pm 10,2$ & $220,0^{\mathrm{a}} \pm 10,5$ & $228,1^{\mathrm{a}} \pm 11,1$ & 0,05 \\
\hline $\mathrm{GP}_{180}, \mathrm{~kg}$ & $137,4^{\mathrm{b}} \pm 10,5$ & $167,1^{\mathrm{a}} \pm 8,9$ & $183,5^{\mathrm{a}} \pm 9,2$ & $184,0^{a} \pm 9,8$ & 0,05 \\
\hline Ingestão de ração, kg MS & $116,7 \pm 15,3$ & $147,5 \pm 13,0$ & $123,2 \pm 13,4$ & $125,0 \pm 14,2$ & NS \\
\hline Ingestão de leite, kg MS & $92,0^{\mathrm{b}} \pm 14,9$ & $112,5^{\mathrm{ab}} \pm 12,7$ & $124,6^{\mathrm{ab}} \pm 13,1$ & $148,8^{a} \pm 13,9$ & 0,01 \\
\hline IMS total, kg & $205,0^{\mathrm{b}} \pm 13,4$ & $260,0^{\mathrm{a}} \pm 11,5$ & $241,9^{\mathrm{a}} \pm 11,8$ & $270,4^{\mathrm{a}} \pm 12,5$ & 0,05 \\
\hline Eficiência, g ganho/kg MS & $659,9^{\mathrm{b}} \pm 31,3$ & $629,5^{\mathrm{b}} \pm 28,0$ & $759,2^{\mathrm{a}} \pm 28,6$ & $684,0^{\mathrm{ab}} \pm 29,7$ & 0,05 \\
\hline Eficiência, g ganho/kg leite & $248,3^{a} \pm 23,8$ & $215,0^{\mathrm{ab}} \pm 20,3$ & $199,4^{\mathrm{ab}} \pm 20,9$ & $164,3^{\mathrm{b}} \pm 22,2$ & 0,05 \\
\hline
\end{tabular}

*letras minúsculas distintas, na mesma linha, representam diferenças estatísticas entre as médias.

em que: $\mathrm{GP}_{180}$ : ganho de peso durante 180 dias de lactação; IMS: ingestão de matéria seca.

$\mathrm{O}$ alto percentual de gordura do leite das vacas NE relaciona-se à menor produção $(\mathrm{P}<0,05)$ e também ao maior $(\mathrm{P}<0,05)$ ganho de peso por quilograma de leite consumido, sendo que os valores observados foram: 248,3 g/kg de leite para Nelore, 215,0 g/kg de leite para $3 / 4 \mathrm{C} 1 / 4 \mathrm{~N}, 199,4 \mathrm{~g} / \mathrm{kg}$ de leite para $1 / 2 \mathrm{C}^{1} / 4 \mathrm{~A} 1 / 4 \mathrm{~N}$ e $164,3 \mathrm{~g} / \mathrm{kg}$ de leite para os bezerros $1 / 2 \mathrm{C}^{1} / 4 \mathrm{~S} 1 / 4 \mathrm{~N}$, confirmando os resultados obtidos por Alencar (1989) quando demonstrou que, quanto maior o potencial de produção das vacas maior a quantidade de leite necessária para produzir um quilograma de ganho, ou seja, os bezerros aleitados pelas melhores produtoras apresentam menor ganho de peso para determinado volume de leite. Pode ser que o melhor desempenho dos bezerros Nelore em converter um quilograma de leite para ganho esteja relacionado à maior EM/kg MS de leite produzido pela vaca NE (Tabela 9). Entretanto, é também possível que o bezerro Nelore tenha menor exigência de mantença e, portanto, melhor conversão alimentar.

Os bezerros $1 / 2 \mathrm{C}^{1} / 4 \mathrm{~A} 1 / 4 \mathrm{~N}$ foram mais eficientes (g ganho de peso/kg MS ingerida) $(\mathrm{P}<0,05)$ do que os bezerros Nelore e $3 / 4 \mathrm{C} 1 / 4 \mathrm{~N}$; os animais $1 / 2 \mathrm{C} 1 / 4 \mathrm{~S} 1 / 4 \mathrm{~N}$ apresentaram eficiência intermediária (Tabela 8). Independente do genótipo, os bezerros machos 
foram mais eficientes ( $\mathrm{P}=0,013)$ do que as fêmeas (720,4 vs. 645,9 g/kg de MS total). É importante enfatizar que nem os índices de ingestão, nem o peso de desmame são indicadores confiáveis quando utilizados sem a descrição do ambiente em que o experimento foi conduzido. Caso as exigências energéticas das vacas cruzadas, que se caracterizaram pela maior IEM (Tabela 6), não tivessem sido supridas, possivelmente, os bezerros provenientes desses cruzamentos não apresentariam o mesmo desempenho. Portanto, não se deve esperar o mesmo desempenho observado quando os animais forem submetidos a condições limitantes de consumo. Mais importante do que a eficiência dos bezerros durante o aleitamento é a eficiência do par vaca/bezerro, que foi estimada e será apresentada adiante.

Os bezerros da raça Nelore apresentaram menor IEM (Tabela 9) e menor ganho de peso. Entretanto, não foram menos eficientes $(\mathrm{P}>0,05)$ em converter megacalorias de energia consumida para gramas de ganho, comparando-os aos bezerros cruzados (Tabela 9). Embora não tenha sido encontrada diferença entre raças, o modelo estatístico revelou efeito de sexo $(\mathrm{P}<0,05)$, independente do cruzamento, indicando melhor desempenho dos machos: 196,1 vs. 172,3 g/Mcal EM. Adiante, no item 4.7, a composição corporal dos bezerros revela maior deposição de extrato etéreo (EE) no corpo vazio das fêmeas, o que possivelmente explica seu menor desempenho em utilizar EM consumida para ganho. 
Tabela 9. Médias ( \pm erro padrão) de ganho de peso, IEM e eficiência de eficiência energética dos bezerros Nelore, $3 / 4 \mathrm{C}^{1} / 4 \mathrm{~N}, 1 / 2 \mathrm{C}^{1} / 4 \mathrm{~A} 1 / 4 \mathrm{~N}$ e $1 / 2 \mathrm{C}^{1} / 4 \mathrm{~S}^{1} / 4 \mathrm{~N}$

\begin{tabular}{lccccc}
\hline & \multicolumn{5}{c}{ Grupo Genético } \\
Variáveis & Nelore & $3 / 4 \mathrm{C}^{1} / 4 \mathrm{~N}$ & $1 / 2 \mathrm{C}^{1 / 4} \mathrm{~A}^{1 / 4} \mathrm{~N}$ & $1 / 2 \mathrm{C}^{1 / 4} \mathrm{~S} 1 / 4 \mathrm{~N}$ & $\mathrm{P}$ \\
\hline $\mathrm{GP}_{180}, \mathrm{~kg}$ & $137,4^{\mathrm{b}} \pm 10,5$ & $167,1^{\mathrm{a}} \pm 8,9$ & $183,5^{\mathrm{a}} \pm 9,2$ & $184,0^{\mathrm{a}} \pm 9,8$ & 0,05 \\
Ingestão de ração, Mcal EM & $273,1 \pm 35,8$ & $345,1 \pm 30,5$ & $288,2 \pm 31,4$ & $292,6 \pm 33,3$ & $\mathrm{NS}$ \\
Ingestão de leite, Mcal EM & $497,2^{\mathrm{b}} \pm 80,3$ & $596,9^{\mathrm{ab}} \pm 80,3$ & $658,4^{\mathrm{ab}} \pm 70,5$ & $772,8^{\mathrm{a}} \pm 74,8$ & 0,05 \\
IEM total, Mcal & $770,3^{\mathrm{b}} \pm 68,8$ & $942,0^{\mathrm{ab}} \pm 58,7$ & $946,7^{\mathrm{ab}} \pm 60,4$ & $1065,4^{\mathrm{a}} \pm 64,1$ & 0,01 \\
EM leite, Mcal/kg MS & $5,40^{\mathrm{a}} \pm 0,07$ & $5,32^{\mathrm{ab}} \pm 0,06$ & $5,25^{\mathrm{ab}} \pm 0,06$ & $5,18^{\mathrm{b}} \pm 0,07$ & 0,05 \\
Eficiência, g ganho/Mcal EM & $184,1 \pm 10,6$ & $178,2 \pm 9,1$ & $197,5 \pm 9,3$ & $176,9 \pm 9,9$ & $\mathrm{NS}$
\end{tabular}

*letras minúsculas distintas, na mesma linha, representam diferenças estatísticas entre as médias;

em que: $\mathrm{GP}_{180}$ : ganho de peso durante 180 dias de lactação; IEM: ingestão de energia metabolizável; EM: energia metabolizável.

Na Figura 5 é representada a comparação do desempenho dos bezerros entre os cruzamentos para a característica ganho de peso, revelando vantagem percentual (aumento de 7\%) do cruzamento AN frente ao sistema utilizando a raça Nelore. Novamente é importante enfatizar que o ambiente experimental não limitou o desempenho dos animais de qualquer grupo, sendo que em condições de restrição nutricional talvez os resultados fossem diferentes. 


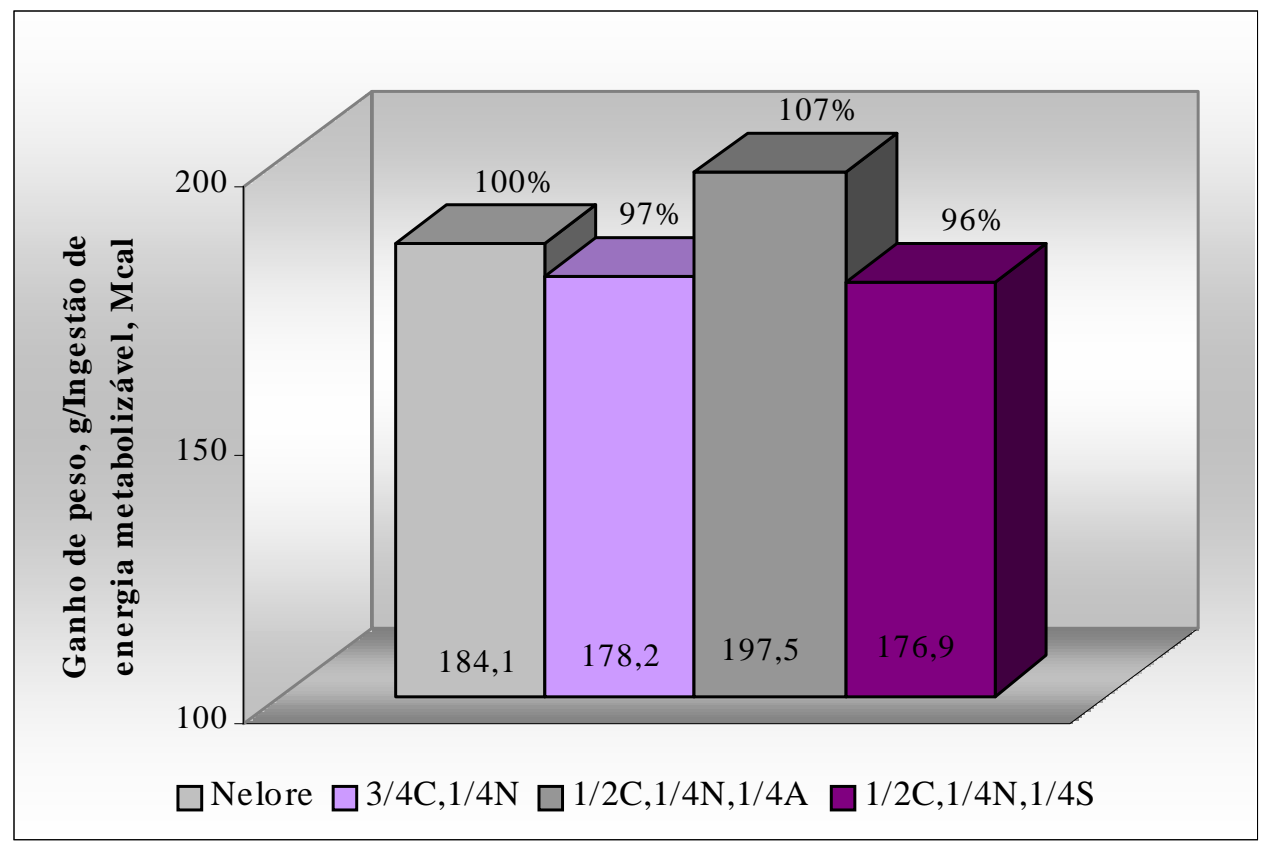

Figura 5 - Eficiência dos bezerros Nelore e cruzados, gramas de ganho/Mcal EM

\subsection{Características da carcaça dos bezerros Nelore, $3 / 4 C^{1 / 4} N, 1 / 2 C^{1 / 4} A^{1 / 4} N^{2}$ e $1 / 2 C^{1 / 4} S^{1 / 4} N$ abatidos aos 180 dias de idade}

\subsubsection{Características mensuradas post mortem}

Os bezerros cruzados, com maior peso de desmame, apresentaram carcaças mais pesadas $(\mathrm{P}<0,01)$, da mesma forma que as medidas de comprimento e profundidade foram superiores $(\mathrm{P}<0,01)$ em relação ao Nelore (Tabela 10).

Uma das expectativas era que ao dividir a soma dos parâmetros profundidade e comprimento pelo peso de desmame em jejum, e correlacionasse o produto resultante com a proporção de EE no corpo vazio, fosse revelado que animais com menor profundidade e comprimento apresentassem maiores percentagens de EE no corpo vazio, fato não demonstrado $(\mathrm{P}=0,73)$ através da correlação. 
Tabela 10. Médias ( \pm erro padrão) dos pesos de carcaça quente, resfriada e medidas de comprimento, profundidade, área de olho de lombo e espessura de gordura subcutânea na $12^{\mathrm{a}}$ costela de bezerros das raças Nelore, 3/4 C1/4 N, 1/2 $\mathrm{C}^{1 / 4} \mathrm{~A} 1 / 4 \mathrm{~N}$ e $1 / 2 \mathrm{C} 1 / 4 \mathrm{~S} 1 / 4 \mathrm{~N}$ ao desmame

\begin{tabular}{lccccc}
\hline & \multicolumn{5}{c}{ Grupo Genético } \\
Variáveis & Nelore & 3/4C $\mathrm{C}^{1 / 4 \mathrm{~N}}$ & $1 / 2 \mathrm{C}^{1} / 4 \mathrm{~A} 1 / 4 \mathrm{~N}$ & $1 / 2 \mathrm{C}^{1 / 4} \mathrm{~S}^{1} / 4 \mathrm{~N}$ & $\mathrm{P}$ \\
\hline Peso de carcaça quente, kg & $99,5^{\mathrm{b}} \pm 6,1$ & $127,2^{\mathrm{a}} \pm 5,7$ & $132,6^{\mathrm{a}} \pm 5,7$ & $140,5^{\mathrm{a}} \pm 6,1$ & 0,01 \\
Peso de carcaça resfriada, kg & $96,9^{\mathrm{b}} \pm 5,9$ & $123,8^{\mathrm{a}} \pm 5,5$ & $129,6^{\mathrm{a}} \pm 5,5$ & $136,9^{\mathrm{a}} \pm 5,9$ & 0,01 \\
Rend. de carcaça quente, \% & $59,1 \pm 0,60$ & $59,8 \pm 0,56$ & $59,0 \pm 0,56$ & $60,4 \pm 0,60$ & $\mathrm{NS}$ \\
AOL, cm ${ }^{2}$ & $41,1^{\mathrm{b}} \pm 2,2$ & $51,3^{\mathrm{a}} \pm 2,0$ & $51,6^{\mathrm{a}} \pm 2,0$ & $57,2^{\mathrm{a}} \pm 2,2$ & 0,01 \\
EGS, mm & $1,72^{\mathrm{a}} \pm 0,26$ & $0,75^{\mathrm{b}} \pm 0,23$ & $1,67^{\mathrm{a}} \pm 0,23$ & $1,21^{\mathrm{ab}} \pm 0,25$ & 0,05 \\
Comp. 1/2 carcaça direita, cm & $91,3^{\mathrm{b}} \pm 1,9$ & $100,8^{\mathrm{a}} \pm 1,7$ & $102,4^{\mathrm{a}} \pm 1,7$ & $102,6^{\mathrm{a}} \pm 1,9$ & 0,01 \\
Comp. 1/2 carcaça esquerda, cm & $91,5^{\mathrm{b}} \pm 1,8$ & $100,5^{\mathrm{a}} \pm 1,7$ & $102,4^{\mathrm{a}} \pm 1,7$ & $102,8^{\mathrm{a}} \pm 1,8$ & 0,01 \\
Prof. 1/2 carcaça direita, cm & $29,6^{\mathrm{b}} \pm 0,43$ & $31,7^{\mathrm{a}} \pm 0,40$ & $31,3^{\mathrm{a}} \pm 0,40$ & $32,4^{\mathrm{a}} \pm 0,43$ & 0,01 \\
Prof. 1/2 carcaça esquerda, cm & $30,0^{\mathrm{c}} \pm 0,44$ & $31,8^{\mathrm{ab}} \pm 0,41$ & $31,3^{\mathrm{b}} \pm 0,41$ & $32,6^{\mathrm{a}} \pm 0,44$ & 0,01 \\
\hline
\end{tabular}

*letras minúsculas distintas, na mesma linha, representam diferenças estatísticas entre as médias;

em que: AOL: área de olho de lombo; EGS: espessura de gordura subcutânea; Rend: rendimento; Comp; comprimento; Prof: profundidade.

A área de olho de lombo, medida na $12^{\mathrm{a}}$ costela, foi maior $(\mathrm{P}<0,01)$ nos bezerros cruzados, caracterizados pelo maior potencial de crescimento das raças Bos taurus, quando comparados aos animais Nelore. Quanto à espessura de gordura subcutânea (EGS), foram obtidos valores maiores $(\mathrm{P}<0,01)$ para Nelore e $1 \frac{1}{2} \mathrm{C} 1 / 4 \mathrm{~A} 1 / 4 \mathrm{~N}$ em relação aos $3 / 4 \mathrm{C} 1 / 4 \mathrm{~N}$, enquanto a deposição de gordura externa nos bezerros $1 / 2 \mathrm{C} 1 / 4 \mathrm{~S} 1 / 4 \mathrm{~N}$ foi intermediária. Embora a raça Nelore não apresente alto potencial de crescimento, esses animais se caracterizam pela deposição precoce de gordura externa.

Observou-se maior EGS (P=0,002) para as fêmeas, independente da raça $(1,8$ vs. 0,9 mm). A maior deposição de energia na forma de tecido adiposo nas fêmeas deve-se ao diferente perfil hormonal destes animais. 


\subsubsection{Massa dos órgãos internos e sua relação com o peso metabólico}

Os bezerros Nelore apresentaram menor $(\mathrm{P}<0,05)$ proporção do peso referente ao fígado, rins e gordura renal e inguinal, órgãos intimamente relacionados à alta atividade metabólica e às exigências de mantença, como já descrito por Truscott et al. (1983), Ferrell \& Jenkins (1985) e Ferrell (1988). Com base nessas referências e nos resultados

obtidos para a proporção de vísceras, pode-se presumir que a exigência energética dos bezerros Nelore é menor do que a exigência dos bezerros cruzados. Isto poderia explicar parte das diferenças na eficiência de ganho conforme já discutido. Entretanto, por apresentam maior exigência para ganho de peso, indicado pela maior EGS desses animais (Tabela 10), eles não se mostraram mais eficientes.

A proporção de gordura renal e inguinal depositada, em relação ao peso metabólico dos bezerros foi maior $(\mathrm{P}=0,02)$ para as fêmeas, independente da raça, 4,75 vs. 2,99\%. Isto confirma a maior eficiência energética das fêmeas em relação aos machos, sendo que ao depositarem mais gordura diluem o custo de mantença (Anrique, 1976). Embora não tenha havido diferença para peso de desmame é comprovado o maior desempenho e eficiência de conversão alimentar dos machos durante a fase de crescimento e terminação, justamente pela maior deposição de tecido magro. No caso dos bezerros, os resultados demonstraram maior desempenho dos machos em converter a energia ingerida para ganho de peso (item 4.5). 
Tabela 11. Médias ( \pm erro padrão) da relação entre massa dos órgãos internos e peso metabólico ao desmame de bezerros Nelore, $3 / 4 \mathrm{C}^{1} / 4 \mathrm{~N}, 1 / 2 \mathrm{C} 1 / 4 \mathrm{~A} 1 / 4 \mathrm{~N}$ e $1 / 2 \mathrm{C}^{1 / 4} \mathrm{~S} 1 / 4 \mathrm{~N}$

\begin{tabular}{lccccc}
\hline & \multicolumn{5}{c}{ Grupo Genético } \\
Variáveis & Nelore & 3/4 $\mathrm{C}^{1} / 4 \mathrm{~N}$ & $1 / 2 \mathrm{C}^{1} / 4 \mathrm{~A} \frac{1}{4} \mathrm{~N}$ & $1 / 2 \mathrm{C}^{1} / 4 \mathrm{~S} 1 / 4 \mathrm{~N}$ & $\mathrm{P}$ \\
\hline Peso ao desmame, $\mathrm{P}^{0,75}$ & $46,5^{\mathrm{b}} \pm 2,1$ & $54,2^{\mathrm{a}} \pm 2,0$ & $56,2^{\mathrm{a}} \pm 2,0$ & $58,2^{\mathrm{a}} \pm 2,1$ & 0,05 \\
Fígado, \% & $4,05^{\mathrm{b}} \pm 0,15$ & $4,54^{\mathrm{a}} \pm 0,14$ & $4,88^{\mathrm{a}} \pm 0,14$ & $4,51^{\mathrm{a}} \pm 0,15$ & 0,05 \\
Rins, \% & $0,93^{\mathrm{b}} \pm 0,05$ & $0,99^{\mathrm{ab}} \pm 0,04$ & $1,04^{\mathrm{ab}} \pm 0,04$ & $1,12^{\mathrm{a}} \pm 0,05$ & 0,05 \\
Coração, \% & $1,48 \pm 0,08$ & $1,64 \pm 0,07$ & $1,65 \pm 0,07$ & $1,70 \pm 0,08$ & $\mathrm{NS}$ \\
Gordura interna, \% & $2,87^{\mathrm{b}} \pm 0,67$ & $3,44^{\mathrm{b}} \pm 0,62$ & $5,87^{\mathrm{a}} \pm 0,62$ & $3,43^{\mathrm{b}} \pm 0,67$ & 0,01 \\
\hline
\end{tabular}

*letras minúsculas distintas, na mesma linha, representam diferenças estatísticas entre as médias;

em que: Gordura interna: gordura renal e inguinal.

\subsection{Estimativa da composição corporal dos bezerros ao desmame}

\subsubsection{Valores percentuais da composição química da 9-10-11 ${ }^{\mathrm{a}}$ costelas e do corpo vazio}

Os teores de água e EE do corte da 9- 10- $11^{\text {a }}$ costelas mostraram-se inversamente proporcionais (Figura 6). Na tabela 13 estão os teores de proteína e cinzas na matéria seca e desengordurada. Os resultados são muito consistentes com aqueles observados em estudos de validação da técnica, nos quais as equações utilizadas neste trabalho foram desenvolvidas.

Os bezerros $1 / 2 \mathrm{C}^{1 / 4} 4 \mathrm{~A}^{1} / 4 \mathrm{~N}$ caracterizaram-se pela alta taxa de crescimento e precocidade da raça Angus, consistente à maior $(\mathrm{P}<0,05)$ proporção de $E E$ e menor $(\mathrm{P}<0,05)$ proporção de água no corte da costela (Tabela 12). Já animais de característica mais tardia, raças Canchim e Simental, apresentaram maiores proporções de água à desemama. As percentagens de EE no corte da costela dos bezerros da raça Nelore diferiram apenas dos dados obtidos para o grupo $3 / 4 \mathrm{C} 1 / 4 \mathrm{~N}$. Independentemente da raça, observou-se maior percentual de água $(\mathrm{P}<0,01)$ e menor percentual de $\mathrm{EE}(\mathrm{P}<0,01)$ nos cortes de costela dos machos. Preston et al. (1963), citados por Simpfendorfer (1974), reportaram que as novilhas da raça Aberdeen Angus abatidas aos 350 kg PV 
apresentaram mais EE e menos água no corte da costela, quando comparadas aos machos da mesma raça abatidos aos $400 \mathrm{~kg}$ : 36,5 e 44,7 vs. 31,2\% EE e 48,3\% água, respectivamente.

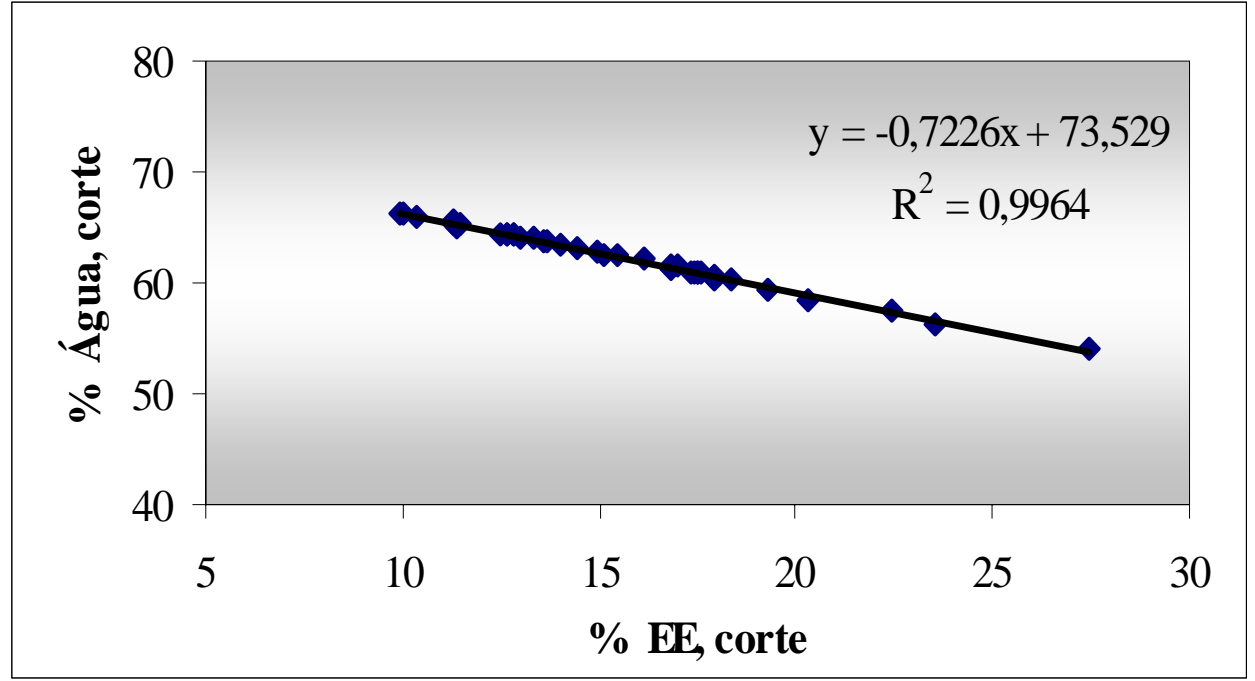

Figura 6 - Correlação das proporções de água e extrato etéreo no corte da 9- $11^{\mathrm{a}}$ costelas de bezerros Nelore e cruzados ao desmame

Anrique (1976) comparou animais das raças Angus e Holandesa e observou maior eficiência energética (kcal no corpo vazio/Mcal ingerida) para o grupo Angus. Apenas as fêmeas da raça Holandesa superaram os machos Angus quando comparados até 90 dias após o desmame. A deposição precoce de gordura subcutânea nos animais Nelore justificaria o alto percentual de EE na composição do corpo vazio dos bezerros desse grupo, embora não se trate de uma raça precoce e sim tardia. Este comportamento aparentemente paradoxal do Nelore é muito importante para definir suas características em um sistema de produção, uma vez que é uma raça que apresenta boa cobertura de gordura a pesos baixos mesmo em um sistema com taxa de crescimento relativamente lenta. Neste estudo, as fêmeas apresentaram maior deposição de EE e menor deposição de água no corpo vazio, \pm 3\%, $(\mathrm{P}<0,01)$ independente do genótipo avaliado, 13,6 e 62,1 vs. 10,4\% EE e 65,2\% água para fêmeas e machos, respectivamente. 
Tabela 12. Composição química do corte da 9- 10- $11^{\mathrm{a}}$ costelas e do corpo vazio de bezerros Nelore, $3 / 4 \mathrm{C} 1 / 4 \mathrm{~N}, 1 / 2 \mathrm{C} 1 / 4 \mathrm{~A} 1 / 4 \mathrm{~N}$ e $1 / 2 \mathrm{C} 1 / 4 \mathrm{~S} 1 / 4 \mathrm{~N}$ ( \pm erro padrão)

\begin{tabular}{lccccc}
\hline & & \multicolumn{2}{c}{ Grupo Genético } & & \\
Variáveis & Nelore & 3/4 $\mathrm{C}^{1 / 4 \mathrm{~N}}$ & $1 / 2 \mathrm{C}^{1} / 4 \mathrm{~A} 1 / 4 \mathrm{~N}$ & $1 / 2 \mathrm{C}^{1 / 4} \mathrm{~S} 1 / 4 \mathrm{~N}$ & $\mathrm{P}$ \\
\hline Água corte, \% & $61,33^{\mathrm{bc}} \pm 0,76$ & $63,80^{\mathrm{a}} \pm 0,72$ & $61,01^{\mathrm{c}} \pm 0,72$ & $63,25^{\mathrm{ab}} \pm 0,76$ & 0,05 \\
EE corte, \% & $16,67^{\mathrm{ab}} \pm 1,11$ & $13,48^{\mathrm{c}} \pm 0,95$ & $17,11^{\mathrm{a}} \pm 0,98$ & $13,77^{\mathrm{bc}} \pm 1,04$ & 0,05 \\
Proteína corte, \% & $18,20^{\mathrm{ab}} \pm 0,32$ & $19,02^{\mathrm{a}} \pm 0,27$ & $17,93^{\mathrm{b}} \pm 0,28$ & $18,86^{\mathrm{a}} \pm 0,30$ & 0,05 \\
Cinzas corte, \% & $4,43 \pm 0,20$ & $4,44 \pm 0,17$ & $4,61 \pm 0,17$ & $4,33 \pm 0,18$ & $\mathrm{NS}$ \\
Água no $\mathrm{P}_{\text {vazio, } \%}$ & $64,65^{\mathrm{a}} \pm 0,87$ & $65,10^{\mathrm{a}} \pm 0,74$ & $61,95^{\mathrm{b}} \pm 0,76$ & $64,77^{\mathrm{a}} \pm 0,81$ & 0,01 \\
EE no $\mathrm{P}_{\text {vazio }} \%$ & $11,76^{\mathrm{ab}} \pm 0,91$ & $10,45^{\mathrm{b}} \pm 0,77$ & $13,69^{\mathrm{a}} \pm 0,79$ & $10,77^{\mathrm{b}} \pm 0,84$ & 0,01 \\
Proteína no $\mathrm{P}_{\text {vazio }} \%$ & $18,87^{\mathrm{b}} \pm 0,038$ & $19,56^{\mathrm{a}} \pm 0,033$ & $19,49^{\mathrm{a}} \pm 0,033$ & $19,56^{\mathrm{a}} \pm 0,036$ & 0,001 \\
Cinzas no $\mathrm{P}_{\text {vazio }} \%$ & $4,72^{\mathrm{b}} \pm 0,009$ & $4,90^{\mathrm{a}} \pm 0,008$ & $4,87^{\mathrm{a}} \pm 0,008$ & $4,89^{\mathrm{a}} \pm 0,009$ & 0,001 \\
\hline
\end{tabular}

*letras minúsculas distintas, na mesma linha, representam diferenças estatísticas entre as médias;

em que: corte: 9- 10- $11^{\text {a }}$ costelas; EE: extrato etéreo; $\mathrm{P}_{\text {vazio }}$ : peso do corpo vazio.

Animais caracterizados pela menor eficiência energética (menor deposição de tecido adiposo) apresentam maior capacidade de deposição de proteína (Anrique, 1976). O mesmo foi observado neste experimento, em que bezerros $1 / 2 \mathrm{C}^{1 / 4} \mathrm{~S} 1 / 4 \mathrm{~N}$ e $3 / 4 \mathrm{C} 1 / 4 \mathrm{~N}$ apresentaram maiores percentuais de proteína $(\mathrm{P}<0,05)$ no corte da costela em relação aos bezerros $1 / 2 \mathrm{C}^{1} / 4 \mathrm{~A} 1 / 4 \mathrm{~N}$. Já os resultados obtidos para a raça Nelore foram intermediários. O efeito do sexo para esta característica favoreceu os machos $(\mathrm{P}<0,01)$; 19,03 vs. 17,97\% de proteína.

Os percentuais de proteína e cinzas do corpo vazio foram maiores $(\mathrm{P}<0,001)$ para os bezerros cruzados em relação aos da raça Nelore. Tanto a proporção de proteína, quanto de água no corpo vazio foram superiores para os machos, independente da raça.

As proporções de proteína e cinzas na matéria seca desengordurada não diferiram $(\mathrm{P}>0,05)$ entre os grupos avaliados (Tabela 13) e mostraram-se muito próximas da relação 80:20. Os resultados deste estudo foram semelhantes aos encontrados por Simpfendorfer (1974) para animais da raça Holandesa abatidos entre os 182 e 184 dias de idade; $81,1 \%$ de proteína e 18,9\% de cinzas, com base na MS e desengordurada. De 
acordo com Anrique (1976), a relação entre proteína e cinzas na matéria seca desengordurada é praticamente constante.

Tabela 13. Médias das relações entre proteína e cinzas na matéria seca desengordurada do corte da 9- 10 - $11^{\mathrm{a}}$ costelas de bezerros aos 180 dias de idade

\begin{tabular}{lccccc}
\hline \multirow{2}{*}{ Variáveis } & \multicolumn{5}{c}{ Grupo Genético } \\
& Nelore & 3/4C1/4N & $1 / 2 \mathrm{C}^{1 / 4 \mathrm{~A}} 1 / 4 \mathrm{~N}$ & $1 / 2 \mathrm{C}^{1 / 4} \mathrm{~S} 1 / 4 \mathrm{~N}$ & $\mathrm{P}$ \\
\hline Proteína corte, \% & $80,40 \pm 0,74$ & $81,06 \pm 0,68$ & $79,64 \pm 0,68$ & $81,42 \pm 0,74$ & $\mathrm{NS}$ \\
Cinzas corte, \% & $19,61 \pm 0,74$ & $18,94 \pm 0,68$ & $20,36 \pm 0,68$ & $18,60 \pm 0,74$ & $\mathrm{NS}$ \\
\hline
\end{tabular}

*Não houve diferença estatística $(\mathrm{P}>0,05)$ entre as médias apresentadas na mesma linha;

em que: corte: 9- 10- $11^{\mathrm{a}}$ costelas.

\subsubsection{Quantidades de água, extrato etéreo, proteína, cinzas e energia do corpo vazio}

O objetivo final de se estimar a composição do corpo vazio é a quantificação dos tecidos depositados e estimativa das exigências líquidas para crescimento. Os dados de composição também permitem estimar a eficiência de deposição, em megacalorias de energia e em quilogramas de proteína, permitindo calcular a relação produto/ingestão e identificar o melhor genótipo para estes parâmetros energéticos até o desmame.

Os bezerros da raça Nelore apresentaram menor peso vazio $(\mathrm{P}<0,05)$ e, conseqüentemente, menores quantidades absolutas dos constituintes químicos do corpo vazio (Tabela 14). As quantidades de água, proteína e cinzas no corpo vazio dos bezerros Nelore foram menores $(\mathrm{P}<0,01)$ do que os valores para os bezerros dos sistemas de cruzamento. A quantidade de EE no corpo vazio foi maior $(\mathrm{P}<0,05)$ para os animais $1 / 2 \mathrm{C}^{1} / 4 \mathrm{~A}^{1} / 4 \mathrm{~N}$ em relação aos da raça Nelore e $3 / 4 \mathrm{C}^{1} / 4 \mathrm{~N}$. Os resultados obtidos para os bezerros $1 / 2 \mathrm{C} 1 / 4 \mathrm{~S} 1 / 4 \mathrm{~N}$ não diferiram dos outros grupos.

As massas de água e EE do corpo vazio para os grupos $1 / 2 \mathrm{C}^{1} / 4 \mathrm{~A} 1 / 4 \mathrm{~N}$ e $1 / 2 \mathrm{C} 1 / 4 \mathrm{~S} 1 / 4 \mathrm{~N}$, embora não diferentes estatisticamente, indicam que animais de característica mais precoce apresentavam maior quantidade de EE e menor conteúdo de água no corpo vazio. O inverso foi observado para os bezerros provenientes do cruzamento da raça Simental (Tabela 14). 
Os bezerros $1 / 2 \mathrm{C} 1 / 4 \mathrm{~A} \frac{1}{4} \mathrm{~N}$ apresentaram mais energia no corpo vazio $(\mathrm{P}<0,05)$ do que os Nelore e $3 / 4 \mathrm{C} 1 / 4 \mathrm{~N}$ (Tabela 14 ), provavelmente em virtude da maior proporção de EE depositada, considerando que o tecido adiposo é sintetizado com eficiência energética superior à deposição de proteína. A energia do corpo vazio dos bezerros Nelore não diferiu do grupo $3 / 4 \mathrm{C} \frac{1}{4} \mathrm{~N}$. A menor eficiência energética destes dois pode ser reflexo da baixa deposição de EE no corpo vazio do Canchim e o baixo peso de desmame do Nelore, já que a percentagem de EE no corpo vazio foi igual à estimada para os bezerros $1 / 2 \mathrm{C} 1 / 4 \mathrm{~A} 1 / 4 \mathrm{~N}$.

Tabela 14. Quantidades ( \pm erro padrão) de água, gordura, proteína, cinzas e energia do corpo vazio de bezerros Nelore, $3 / 4 \mathrm{C}^{1} / 4 \mathrm{~N}, 1 / 2 \mathrm{C}^{1} / 4 \mathrm{~A} 1 / 4 \mathrm{~N}$ e $1 / 2 \mathrm{C}^{1 / 4} \mathrm{~S} 1 / 4 \mathrm{~N}$ ao desmame

\begin{tabular}{lccccc}
\hline & \multicolumn{5}{c}{ Grupo Genético } \\
Variáveis & Nelore & 3/4C1/4N & $1 / 2 \mathrm{C}^{1} / 4 \mathrm{~A} 1 / 4 \mathrm{~N}$ & $1 / 2 \mathrm{C}^{1} / 4 \mathrm{~S} 1 / 4 \mathrm{~N}$ & $\mathrm{P}$ \\
\hline $\mathrm{P}_{\text {vazio }}$ kg & $149,1^{\mathrm{b}} \pm 9,6$ & $183,1^{\mathrm{a}} \pm 8,9$ & $192,8^{\mathrm{a}} \pm 8,9$ & $201,3^{\mathrm{a}} \pm 9,6$ & 0,05 \\
Água $\mathrm{P}_{\text {vazio }}, \mathrm{kg}$ & $95,1^{\mathrm{b}} \pm 5,57$ & $119,0^{\mathrm{a}} \pm 5,12$ & $120,5^{\mathrm{a}} \pm 5,15$ & $131,4^{\mathrm{a}} \pm 5,56$ & 0,01 \\
EE $\mathrm{P}_{\text {vazio }}, \mathrm{kg}$ & $17,5^{\mathrm{b}} \pm 2,26$ & $19,3^{\mathrm{b}} \pm 2,10$ & $26,5^{\mathrm{a}} \pm 2,10$ & $21,9^{\mathrm{ab}} \pm 2,26$ & 0,05 \\
Proteína $\mathrm{P}_{\text {vazio }}, \mathrm{kg}$ & $27,8^{\mathrm{b}} \pm 1,8$ & $35,8^{\mathrm{a}} \pm 1,7$ & $37,8^{\mathrm{a}} \pm 1,7$ & $39,7^{\mathrm{a}} \pm 1,8$ & 0,01 \\
Cinzas $\mathrm{P}_{\text {vazio }}, \mathrm{kg}$ & $6,9^{\mathrm{b}} \pm 0,46$ & $8,9^{\mathrm{a}} \pm 0,42$ & $9,4^{\mathrm{a}} \pm 0,42$ & $9,9^{\mathrm{a}} \pm 0,46$ & 0,01 \\
Energia $\mathrm{P}_{\text {vazio }}$, Mcal & $321,8^{\mathrm{c}} \pm 30,0$ & $384,0^{\mathrm{bc}} \pm 27,6$ & $462,6^{\mathrm{a}} \pm 27,7$ & $429,8^{\mathrm{ab}} \pm 29,9$ & 0,05 \\
\hline
\end{tabular}

*letras minúsculas distintas, na mesma linha, representam diferenças estatísticas entre as médias;

em que: $\mathrm{P}_{\text {vazio }}$ : peso do corpo vazio; EE: extrato etéreo.

\subsection{Ingestão e eficiência do par vaca/bezerro}

\subsection{1 Índices com base na matéria seca}

O consumo do par vaca/bezerro (Tabela 15) foi maior para o grupo SN $(\mathrm{P}<0,05)$. Os grupos AN e CN não diferiram entre si, enquanto os pares NE/Nelore apresentaram menor IMS em relação aos demais genótipos. Esses diferentes potenciais de ingestão, como já afirmado por Armstrong et al. (1990), relacionam-se às diferenças nas exigência 
das vacas e dos bezerros. Segundo Fox \& George (1986), as exigências da unidade vaca/bezerro são determinadas pela demanda de produção, dependente dos potenciais de produção de leite e de crescimento, além das necessidades de mantença, sendo estas, determinadas pelo tamanho corporal e pela característica do ambiente (IMS).

A eficiência, ganho/consumo de matéria seca pela unidade vaca/bezerro, foi maior $(\mathrm{P}<0,05)$ para o par $\mathrm{AN} / 1 / 2 \mathrm{C}^{1} / 4 \mathrm{~A}^{1} / 4 \mathrm{~N}$ em relação ao par NE/Nelore, 110,8 vs. 92,4 g de ganho/kg MS. Os pares $\mathrm{CN} / 3 / 4 \mathrm{C}^{1} / 4 \mathrm{~N}$ e $\mathrm{SN} / 1 / 2 \mathrm{C} 1 / 4 \mathrm{~S} 1 / 4 \mathrm{~N}$ apresentaram eficiência entre esses valores, não diferindo dos outros dois grupos (Tabela 15). Os resultados demonstram que a IMS pelo grupo $\mathrm{AN} / \frac{1}{2} \mathrm{C} 1 / 4 \mathrm{~A} 1 \frac{1}{4} \mathrm{~N}$ foi mais do que compensada pelo elevado ganho de peso e peso de desmame. Jenkins \& Ferrell (1993) afirmaram que raças ou cruzamentos caracterizados por potenciais de crescimento e produção de leite intermediários são mais eficientes em converter alimento em ganho de peso dos bezerros durante o aleitamento, assumindo que as exigências das vacas sejam atendidas.

Tabela 15. Médias ( \pm erro padrão) de ingestão, ganho de peso dos bezerros e eficiência em gramas de ganho/kg de MS consumido pela vaca/bezerro Nelore e seus cruzamentos com Bos taurus

\begin{tabular}{|c|c|c|c|c|c|}
\hline \multirow[b]{2}{*}{ Variáveis } & \multicolumn{4}{|c|}{ Unidade vaca/bezerro } & \multirow[b]{2}{*}{$\mathrm{P}$} \\
\hline & NE/Nelore & $\mathrm{CN} / 3 / 4 \mathrm{C}^{1} / 4 \mathrm{~N}$ & $\mathrm{AN} / 1 / 2 \mathrm{C}^{1} / 4 \mathrm{~A} 1 / 4 \mathrm{~N}$ & $\mathrm{SN} / 1 / 2 \mathrm{C}^{1 / 4} \mathrm{~S}^{1 / 4} \mathrm{~N}$ & \\
\hline IMS vaca, kg & $1391,6^{\mathrm{C}} \pm 35,1$ & $1466,9^{\mathrm{bc}} \pm 35,1$ & $1541,6^{\mathrm{b}} \pm 35,1$ & $1651,9^{a} \pm 35,1$ & 0,05 \\
\hline IMS bezerro, kg ração & $116,7 \pm 15,3$ & $147,5 \pm 13,0$ & $123,2 \pm 13,4$ & $125,0 \pm 14,2$ & NS \\
\hline IMS par, kg & $1508,3^{c} \pm 36,3$ & $1614,4^{b} \pm 34,5$ & $1665,9^{b} \pm 34,5$ & $1799,8^{\mathrm{a}} \pm 36,3$ & 0,05 \\
\hline $\mathrm{GP}_{180}, \mathrm{~kg}$ & $137,4^{b} \pm 10,5$ & $167,1^{\mathrm{a}} \pm 8,9$ & $183,5^{\mathrm{a}} \pm 9,2$ & $184,0^{\mathrm{a}} \pm 9,8$ & 0,05 \\
\hline Efic par, g GP/Kg MS & $92,5^{\mathrm{b}} \pm 6,5$ & $103,2^{\mathrm{ab}} \pm 5,5$ & $110,8^{\mathrm{a}} \pm 5,7$ & $102,8^{\mathrm{ab}} \pm 6,0$ & 0,05 \\
\hline
\end{tabular}

*letras minúsculas distintas, na mesma linha, representam diferenças estatísticas entre as médias;

em que: IMS: ingestão de matéria seca; $\mathrm{GP}_{180}$ : ganho de peso durante 180 dias de lactação.

O tamanho adulto ou a ingestão de matéria seca não são, isoladamente, indicadores da eficiência. Enquanto Wilton et al. (1974) e Armstrong et al. (1990) reportaram que vacas maiores, de maior potencial de produção de leite e desmamando bezerros mais pesados, foram mais eficientes do que as de menor tamanho corporal, 
Dinkel \& Brown (1978) encontraram que as vacas mais eficientes em converter quilograma de nutrientes digestíveis totais (NDT) em quilograma de bezerro desmamado foram as de menor tamanho corporal (8,99 vs. 15,8 kg NDT/kg PV). Estes autores concluíram que a interação do tamanho corporal com o plano nutricional de um sistema de produção interfere tanto na fertilidade, quanto na eficiência total do sistema.

\subsection{2 Índices com base na energia metabolizável}

A IEM do par $\mathrm{SN} / 1 \frac{1}{2} \mathrm{C} 1 / 4 \mathrm{~S} 1 / 4 \mathrm{~N}$ foi maior $(\mathrm{P}<0,05)$ em relação aos demais grupos (Tabela 16). Na Figura 7 está representada a IEM dos pares vaca/bezerro e as médias dos pesos ao nascimento e ao desmame, demonstrando a relação positiva entre “input” e “output”.

A relação de ingestão e ganho de peso, característica dependente do potencial de crescimento de cada raça, revela maior eficiência ( $\mathrm{P}<0,05$; Figura 8) para o grupo com IEM intermediária e alto peso de desmame, do par $\mathrm{AN} / 1 \frac{1}{2} \mathrm{C} 1 / 4 \mathrm{~A} 1 \frac{1}{4} \mathrm{~N}$. $\mathrm{O}$ alto ganho de peso durante o aleitamento, novamente, mais do que compensou o a ingestão intermediária do par e o baixo peso ao nascimento dos bezerros $1 / 2 \mathrm{C} 1 / 4 \mathrm{~A} 1 / 4 \mathrm{~N}$. Uma justificativa para 0 melhor desempenho de animais mais exigentes utilizada por Armstrong et al. (1990) é que as raças maiores exercem maior efeito direto sobre o peso de desmame do que as raças menores (menor produção de leite). Este efeito positivo é mais acentuado pela heterose propiciada com a utilização da tecnologia dos cruzamentos.

É importante notar que os resultados observados poderiam ser diferentes caso os touros Angus escolhidos fossem de menor peso adulto, mas de elevada precocidade. Isto porque o peso adulto das vacas cruzadas poderia ser menor e a eficiência maior.

Outro parâmetro de eficiência considerado foi a relação entre quilograma de ganho dos bezerros e peso metabólico das vacas $\left(\mathrm{P}^{0,75}\right)$. Dinkel \& Brown (1978) sugeriram que a utilização do peso metabólico da vaca permite a comparação dos pares vaca/bezerro de forma ajustada. Os resultados deste parâmetro (Tabela 16) revelam melhor desempenho $(\mathrm{P}<0,05)$ da unidade $\mathrm{AN} / 1 / 2 \mathrm{C}^{1} / 4 \mathrm{~A} 1 / 4 \mathrm{~N}$ em relação ao par NE/Nelore, tendo os pares $\mathrm{CN} / 3 / 4 \mathrm{C} 1 / 4 \mathrm{~N}$ e $\mathrm{SN} / 1 \frac{1}{2} \mathrm{C}_{1}^{1} / 4 \mathrm{~S}^{1} / 4 \mathrm{~N}$ apresentado eficiência intermediária. Para 
este parâmetro de eficiência, a análise de variância revelou melhor desempenho dos machos $(\mathrm{P}=0,059)$ em relação às fêmeas, independente da raça; 1,8 vs. 1,6 kg ganho/kg $\mathrm{P}^{0,75}$.

Tabela 16. Médias ( \pm erro padrão) de ingestão de EM, ganho de peso dos bezerros, eficiência de conversão de energia e a relação entre pesos do bezerro e da vaca

\begin{tabular}{|c|c|c|c|c|c|}
\hline \multirow[b]{2}{*}{ Variáveis } & \multicolumn{4}{|c|}{ Unidade vaca/bezerro } & \multirow[b]{2}{*}{$\mathrm{P}$} \\
\hline & NE/Nelore & $\mathrm{CN} / 3 / 4 \mathrm{C}^{1} / 4 \mathrm{~N}$ & $\mathrm{AN} / 1 / 2 \mathrm{C}^{1} / 4 \mathrm{~A}^{1} / 4 \mathrm{~N}$ & $\mathrm{SN} / 1 / 2 \mathrm{C}^{1} / 4 \mathrm{~S}^{1} / 4 \mathrm{~N}$ & \\
\hline IEM vaca, Mcal & $3118,4^{\mathrm{c}} \pm 78,6$ & $3287,2^{\mathrm{bc}} \pm 78,6$ & $3454,5^{b} \pm 78,6$ & $3701,9^{\mathrm{a}} \pm 78,6$ & 0,05 \\
\hline IEM bez, Mcal ração & $273,1 \pm 35,8$ & $345,1 \pm 30,5$ & $288,2 \pm 31,4$ & $292,6 \pm 33,3$ & NS \\
\hline IEM par, Mcal & $3392,0^{c} \pm 81,7$ & $3632,3^{\mathrm{b}} \pm 77,5$ & $3745,3^{\mathrm{b}} \pm 77,5$ & $4045,9^{\mathrm{a}} \pm 81,7$ & 0,05 \\
\hline $\mathrm{GP}_{180}, \mathrm{~kg}$ & $137,4^{b} \pm 10,5$ & $167,1^{\mathrm{a}} \pm 8,9$ & $183,5^{a} \pm 9,2$ & $184,0^{\mathrm{a}} \pm 9,8$ & 0,05 \\
\hline Efic, g GP/Mcal EM & $40,7^{b} \pm 2,5$ & $45,9^{\mathrm{ab}} \pm 2,4$ & $48,5^{\mathrm{a}} \pm 2,4$ & $45,2^{\mathrm{ab}} \pm 2,5$ & 0,05 \\
\hline Efic, kg GP/kg $\mathrm{P}^{0,75}$ vaca & $1,47^{\mathrm{b}} \pm 0,10$ & $1,72^{\mathrm{ab}} \pm 0,09$ & $1,76^{\mathrm{a}} \pm 0,09$ & $1,74^{\mathrm{ab}} \pm 0,10$ & 0,05 \\
\hline
\end{tabular}

*letras minúsculas distintas, na mesma linha, representam diferenças estatísticas entre as médias;

em que: $\mathrm{GP}_{180}$ : ganho de peso durante 180 dias de lactação; IEM: ingestão de energia metabolizável; EM: energia.metabolizável; Efic g/Mcal: eficiência do par em gramas de ganho/Mcal IEM par; Efic kg/kg $\mathrm{P}^{0,75}$ : eficiência do par em quilogramas de ganho/quilograma de peso metabólico de vaca. 

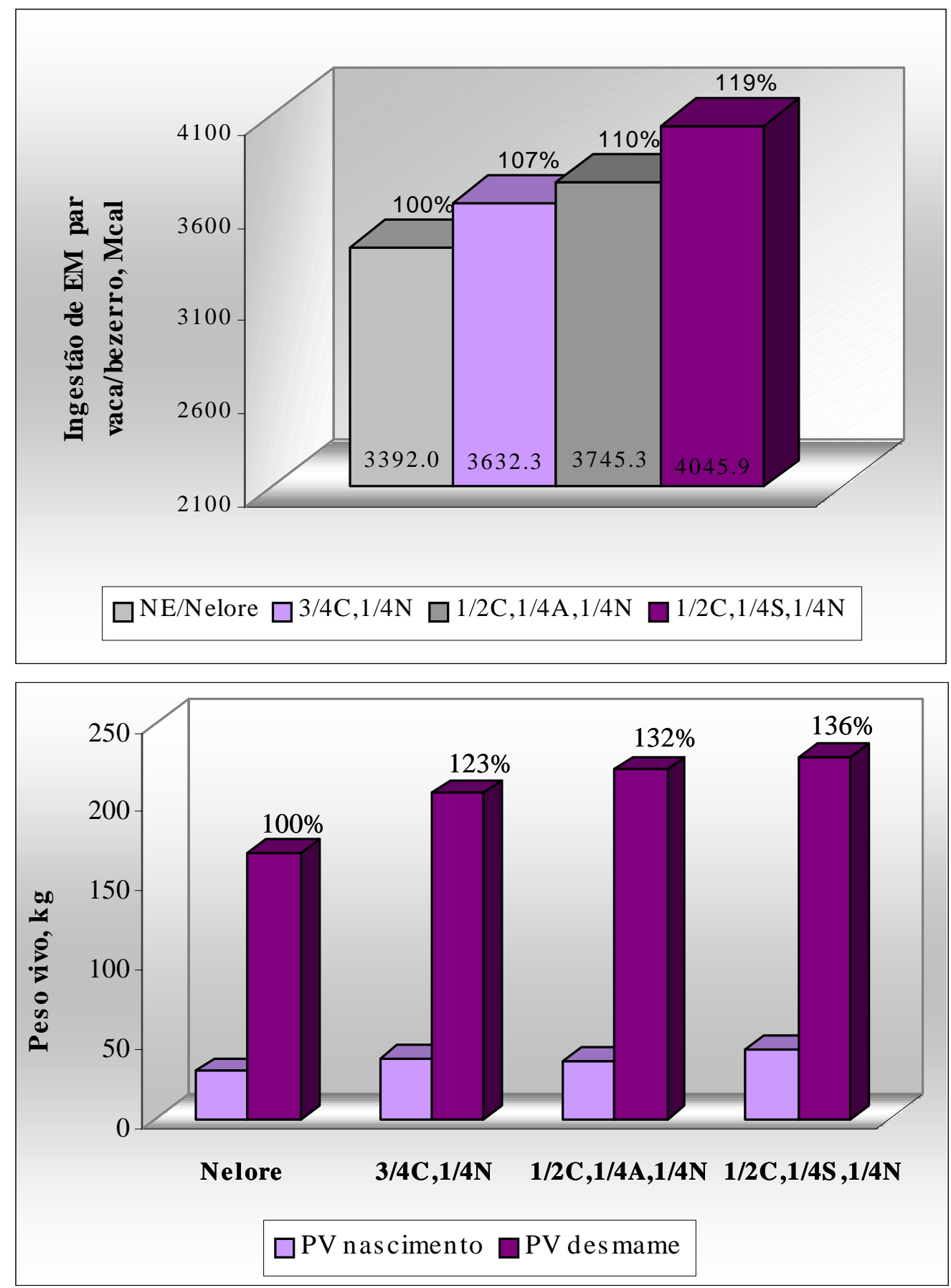

Figura 7 - Relação positiva entre ingestão da unidade vaca/bezerro e pesos ao nascimento e ao desmame dos grupos Nelore e cruzamentos de Canchim, Angus e Simental 


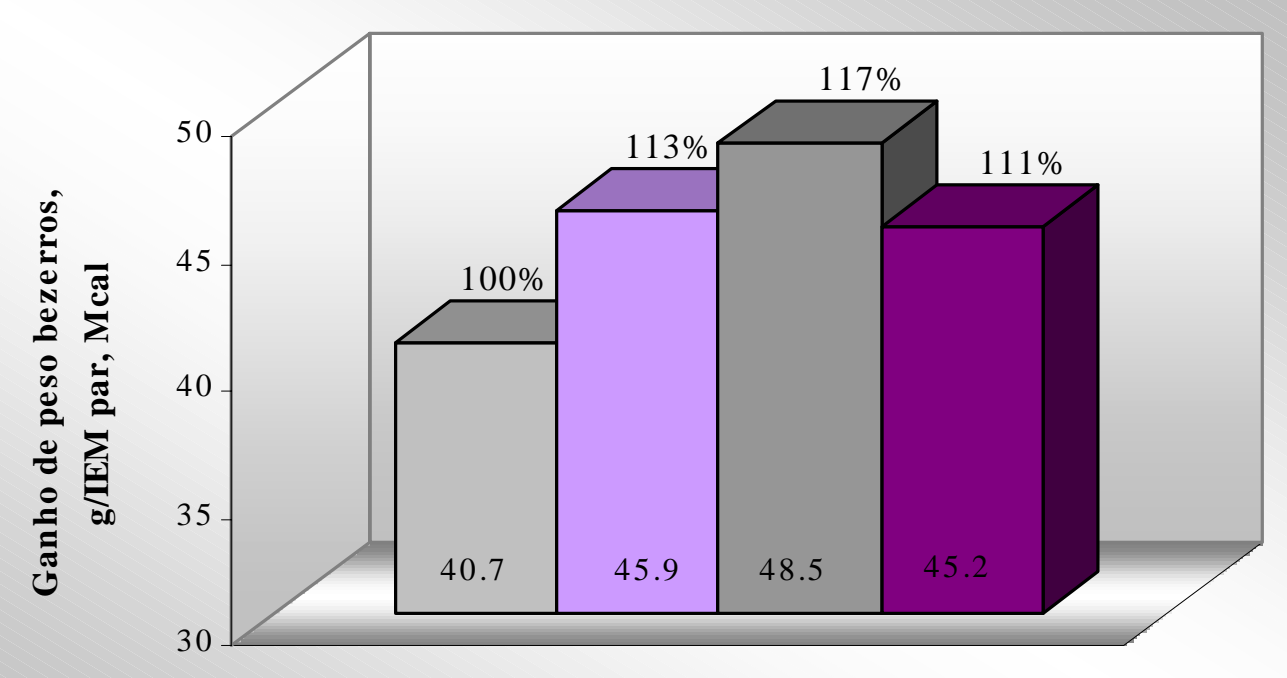

$\square$ NE-Nelore $\square$ CN-3/4C,1/4N $\square$ AN-1/2C,1/4A,1/4N $\square$ SN-1/2C,1/4S,1/4N

Figura 8 - Eficiência de conversão de energia dos pares vaca/bezerro Nelore/Nelore, Canchim x Nelore $/ \frac{3}{4} \mathrm{C}^{1} / 4 \mathrm{~N}$, Angus $\mathrm{x}$ Nelore $/ \frac{1}{2} \mathrm{C}^{1 / 1} / \mathrm{A}^{1} / 4 \mathrm{~N}$ e Simental $\mathrm{x}$ Nelore $/ 1 / 2 \mathrm{C}^{1} / 4 \mathrm{~S}^{1} / 4 \mathrm{~N}$

A maior eficiência de grupos caracterizados por tamanho corporal mediano e potencial de produção de leite intermediário havia sido demonstrada em outros experimentos, como Jenkins et al. (1991) e Jenkins \& Ferrell (1993). Os primeiros concluíram que quando vacas de tamanho e potencial de produção intermediários são inseminadas com sêmen de touros provados e caracterizados pelo alto potencial genético de crescimento, o resultado seria de complementaridade, influenciando positivamente a eficiência de utilização da EM durante o período de aleitamento.

Green et al. (1991) consideraram que a eficiência do par vaca bezerro foi potencialmente favorecida pela heterose ocasionada pelo cruzamento entre raças Bos indicus x Bos taurus, ao encontrarem que os grupamentos Brahman x Angus ou Brahman x Hereford de maior peso adulto e maior produção de leite foram, em média, $11 \%$ mais eficientes do que os animais cruzados Bos taurus x Bos taurus. Os autores consideraram a vantagem de 11\% um valor de importância econômica. Cundiff et al. (1983), em Green et al. (1991), consideraram que grupos com menor ingestão 
apresentam maior eficiência no ciclo total de produção. No entanto, sabe-se da importância da taxa de crescimento e da precocidade dos bezerros para a produção de novilhos ao abate, sendo assim a produção de bezerros maiores por vacas menores aumentaria a relação “output”/“input”.

Montaño-Bermudez \& Nielsen (1990) avaliaram o sistema como um todo, utilizando fêmeas F1 de mesmo tamanho adulto, mas diferentes quanto ao potencial de produção de leite (alta, “A”, moderada, “M” e baixa produção, “B”) e observaram maior exigência energética até o desmame para o grupo “A” e menor exigência para o grupo “B”, que apresentou maior eficiência de conversão de energia até o abate. Caso os autores não houvessem optado pelo peso de abate fixo a progênie de linhagem leiteira poderia não ter sido prejudicada pela maior deposição de gordura interna, o que possivelmente diminuiu o rendimento de carcaça dos animais referentes ao grupo "A”.

Deve-se priorizar não só a obtenção de dados de eficiência durante a fase de aleitamento ou crescimento isoladamente, mas de todo período de produção, estimandose até que ponto uma vaca mais eficiente até o desmame seria mais eficiente em produzir um novilho ao abate, considerando que vacas com maior potencial de produção (maior exigência/kg $\mathrm{P}^{0,75}$ ) caracterizam-se por produzir animais mais exigentes durante toda fase de crescimento e terminação.

\subsubsection{Eficiência energética - kcal do corpo vazio/Mcal de EM ingerida pela unidade vaca/bezerro}

A unidade $\mathrm{AN} / 1 \frac{1}{2} \mathrm{C}^{1} / 4 \mathrm{~A} 1 / 4 \mathrm{~N}$ apresentou maior eficiência energética $(\mathrm{P}<0,05)$, Mcal de energia depositada no corpo vazio/Mcal de EM ingerida, em comparação ao grupo NE/Nelore. Os cruzamentos com as raças Canchim e Simental apresentaram eficiência semelhante aos dois grupos mencionados (Tabela 17). A maior eficiência energética relacionou-se positivamente ao alto peso de desmame e IEM intermediária do par $\mathrm{AN} / 1 \frac{1}{2} \mathrm{C} 1 / 4 \mathrm{~A} \frac{1}{4} \mathrm{~N}$, quando avaliados em ambiente favorável. As eficiências energéticas do par vaca/bezerro estão ilustradas na Figura 9. 
Tabela 17. Médias ( \pm erro padrão) da IEM da unidade vaca/bezerro e da deposição de energia no corpo vazio do bezerro ao longo da lactação, do peso vazio ao desmame, e da eficiência de conversão de energia dos diferentes grupos genéticos

\begin{tabular}{lccccc}
\hline \multirow{2}{*}{ Variáveis } & \multicolumn{4}{c}{ Unidade vaca/bezerro } & \\
& NE/Nelore & CN/3/4C1/4N & AN/1/2C1/4A1/4N & SN/1/2C1/4S1/4N & $P$ \\
\hline IEM par, Mcal/lactação & $3392,0^{\mathrm{c}} \pm 81,7$ & $3632,3^{\mathrm{b}} \pm 77,5$ & $3745,3^{\mathrm{b}} \pm 77,5$ & $4045,9^{\mathrm{a}} \pm 81,7$ & 0,05 \\
$\mathrm{P}_{\text {vazio }}$, kg & $149,1^{\mathrm{b}} \pm 9,6$ & $183,1^{\mathrm{a}} \pm 8,9$ & $192,8^{\mathrm{a}} \pm 8,9$ & $201,3^{\mathrm{a}} \pm 9,6$ & 0,05 \\
Energia $\mathrm{P}_{\text {vazio }}$, Mcal & $321,8^{\mathrm{c}} \pm 30,0$ & $384,0^{\mathrm{bc}} \pm 27,6$ & $462,6^{\mathrm{a}} \pm 27,7$ & $429,8^{\mathrm{ab}} \pm 29,9$ & 0,05 \\
Eficiência, kcal /Mcal & $95,8^{\mathrm{b}} \pm 7,2$ & $105,2^{\mathrm{ab}} \pm 6,8$ & $124,4^{\mathrm{a}} \pm 6,8$ & $107,0^{\mathrm{ab}} \pm 7,2$ & 0,05
\end{tabular}

*letras minúsculas distintas, na mesma linha, representam diferenças estatísticas entre as médias;

em que: IEM: ingestão de energia metabolizável; $\mathrm{P}_{\text {vazio }}$ : peso vazio do bezerro ao desmame; Eficiência: kcal $\mathrm{P}_{\text {vazio }}$ /Mcal IEM par.

A figura 9 sugere que o sistema de cruzamento com B. taurus permitiu ganho mínimo de $10 \%$ na eficiência. Ressalta-se a importância de estudos que dêem continuidade a este trabalho, avaliando a reprodução e que sejam capazes de comprovar a maior eficiência energética e econômica dos cruzamentos, quando explorados em diferentes condições de produção. Os valores representam ganhos de eficiência biológica, enfatizando que o desempenho obtido para os animais cruzados foi mensurado em condições nutricionais adequadas. 


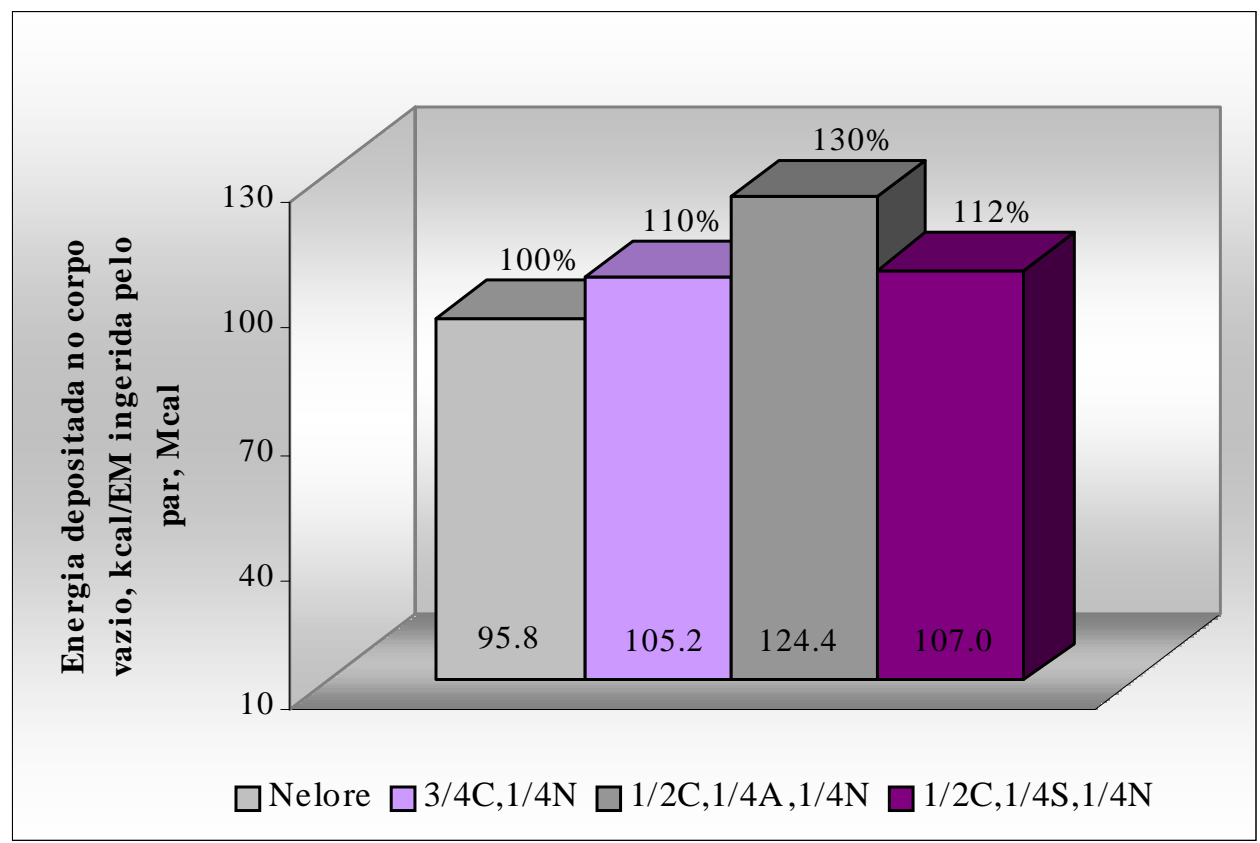

Figura 9 - Variação da eficiência da unidade vaca/bezerro aos 180 dias de lactação, com base no mínimo observado para o par NE/Nelore

\subsubsection{Eficiência protéica - gramas de proteína depositada no corpo vazio/kg de proteína ingerida pela unidade vaca/bezerro}

A quantidade de proteína ingerida pela unidade vaca/bezerro, assim como a quantidade de energia, segue a diferença de consumo das mães e já que não houve diferença para a IMS entre os bezerros, a fração protéica ingerida pelas crias também foi igual ( $\mathrm{P}>0,05)$ entre os genótipos (Tabela 18).

Estes resultados devem ser avaliados com muito cuidado, uma vez que a dieta utilizada continha teores elevados de proteína e é possível que as exigências de proteína sejam diferentes entre os grupos genéticos. O objetivo foi evitar que algum genótipo tivesse deficiência de proteína. Desta forma, animais que receberam quantidades de proteína dietética maiores que as suas exigências apresentariam eficiências protéicas subestimadas.

Os resultados de eficiência protéica deste trabalho também não podem ser utilizados como parâmetros ambientais, pois como exposto acima, devem ser 
subestimados, em função do alto teor de proteína da dieta, provavelmente superior ao obtido por vacas na maior parte das condições de produção do Brasil Central.

As vacas SN, que apresentaram maior IMS, consumiram mais proteína $(\mathrm{P}<0,05)$ do que as vacas dos outros grupos genéticos; 264,3 kg vs. 222,7 kg para NE, 234,7 kg para CN e 246,6 kg de proteína para as vacas AN.

A eficiência em depositar proteína está relacionada ao potencial de crescimento dos bezerros e como demonstrado nos itens anteriores pôde-se observar maior desempenho dos animais cruzados. As unidades $\mathrm{AN} / 1 \frac{1}{2} \mathrm{C} 1 / 4 \mathrm{~A} 1 \frac{1}{4} \mathrm{~N}$ e $\mathrm{CN} / 3 / 4 \mathrm{C} 1 / 4 \mathrm{~N}$ apresentaram maior eficiência protéica, ou seja, o “output” (quantidade de proteína depositada no corpo vazio dos bezerros aos 180 dias de idade) compensou a maior quantidade de proteína ingerida pelo par vaca/bezerro (Tabela 18). Por outro lado, a alta ingestão das vacas SN não foi compensada pela alta taxa de crescimento dos bezerros. Embora, as vacas CN não apresentem elevado peso adulto, a progênie se caracterizou pela alta taxa de crescimento, apresentando peso de desmame semelhante aos outros cruzamentos caracterizados pelo maior tamanho adulto.

Tabela 18. Médias ( \pm erro padrão) de ingestão, deposição e eficiência de conversão de proteína das unidades vaca/bezerro de grupos genéticos distintos

\begin{tabular}{|c|c|c|c|c|c|}
\hline \multirow[b]{2}{*}{ Variáveis } & \multicolumn{4}{|c|}{ Unidade vaca/bezerro } & \multirow[b]{2}{*}{$\mathrm{P}$} \\
\hline & NE/Nelore & $\mathrm{CN} / 3 / 4 \mathrm{C}^{1} / 4 \mathrm{~N}$ & $\mathrm{AN} / 1 / 2 \mathrm{C}^{1 / 4} / \mathrm{A}^{1 / 4} \mathrm{~N}$ & $\mathrm{SN} / 1 / 2 \mathrm{C}^{1 / 4} \mathrm{~S}^{1 / 4} \mathrm{~N}$ & \\
\hline Ingestão da vaca, kg PB & $222,7^{\mathrm{c}} \pm 5,3$ & $234,7^{\mathrm{b}} \pm 5,3$ & $246,6^{\mathrm{b}} \pm 5,3$ & $264,3^{a} \pm 5,3$ & 0,05 \\
\hline Ingestão do bezerro, kg PB & $19,4 \pm 2,1$ & $23,6 \pm 1,2$ & $19,9 \pm 1,2$ & $20,3 \pm 2,1$ & NS \\
\hline Ingestão do par, kg PB & $241,9^{c} \pm 5,2$ & $258,3^{\mathrm{b}} \pm 4,8$ & $266,5^{\mathrm{b}} \pm 4,8$ & $288,6^{a} \pm 5,2$ & 0,05 \\
\hline Eficiência, g/kg & $117,0^{\mathrm{b}} \pm 7,5$ & $138,3^{\mathrm{a}} \pm 6,9$ & $141,4^{\mathrm{a}} \pm 6,9$ & $136,9^{\mathrm{ab}} \pm 7,5$ & 0,05 \\
\hline
\end{tabular}

*letras minúsculas distintas, na mesma linha, representam diferenças estatísticas entre as médias; em que: PB: proteína bruta; Eficiência: g de proteína no corpo vazio/kg PB ingerido pelo par.

Na Figura 10 está ilustrada a relação entre os genótipos avaliados para eficiência protéica. Pode-se observar que, mesmo apresentando alto consumo o par vaca/bezerro SN foi17\% mais eficientes do que a unidade NE. Entretanto, mais interessante do que os 
resultados biológicos seria a conversão para custos de “input” e “output” dos cruzamentos distintos, para os diferentes parâmetros de eficiência abordados.

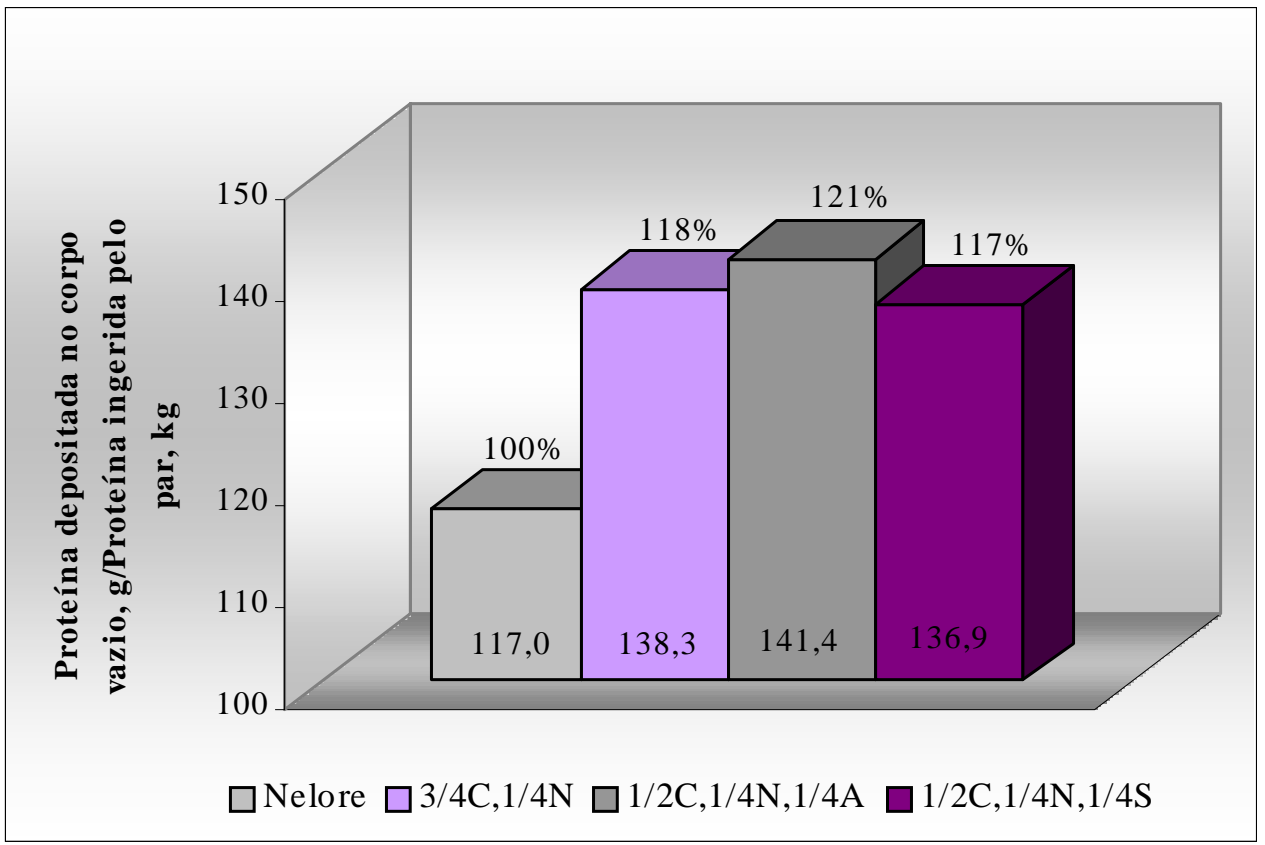

Figura 10 -Eficiência de conversão de proteína da unidade vaca/bezerro

Os dados deste experimento sugerem que a mais vantajosa opção seria utilizar matrizes de baixo “input” (Nelore) cruzadas com touros de alto “output” (bezerros 1/2 sangue Bos taurus x Bos indicus). Estes animais iriam também se beneficiar da heterose. Infelizmente não havia um grupo com estas características para comparação. Enfatiza-se que não se deve descartar a possibilidade de escolha entre raças de maior porte e maior potencial de crescimento, desde que o ambiente seja favorável e capaz de suprir as exigências específicas do genótipo determinado, possibilitando o desempenho máximo dos animais dentro do sistema de produção pré-estabelecido. 


\subsection{Correlações}

A IMS das vacas se correlacionou positivamente com o potencial de produção de leite $(\mathrm{P}=0,02)$, explicando o maior consumo das vacas $\mathrm{SN}$. Pode-se observar que os parâmetros de desempenho dos bezerros (Tabela 19) e de eficiência da unidade vaca/bezerro (Tabela 20) se correlacionaram positivamente com a produção de leite. Entretanto, as vacas SN, que apresentaram maior produção de leite não foram mais eficientes em converter energia/proteína para deposição de tecido no corpo vazio dos bezerros, possivelmente pela maior IMS não ter sido minimizada pelo “output”.

As correlações (Tabela 20) sugerem que o maior desempenho da unidade vaca/bezerro não se correlaciona ao peso adulto e potencial de crescimento, sendo estas as características de maior ênfase nos programas de seleção e melhoramento genético.

Tabela 19. Correlações corrigidas para efeito de grupo genético (análise multivariada), entre características maternas de ingestão e produção de leite com o desempenho dos bezerros

\begin{tabular}{lcccc}
\hline Variáveis & \multicolumn{2}{c}{ Vaca } & \multicolumn{2}{c}{ Bezerro } \\
Independentes & Ingestão de MS & Produção de leite & Peso de desmame & Ganho de peso \\
\hline Ingestão de MS & - & $0,37(0,02)$ & - & - \\
Produção de leite & $0,37(0,02)$ & - & $0,50(0,002)$ & $0,51(0,002)$ \\
\hline
\end{tabular}

Significância das correlações entre parênteses;

em que: MS: matéria seca.

Tabela 20. Correlações corrigidas para efeito de grupo genético (análise multivariada), entre características maternas de peso e produção de leite com o desempenho da unidade vaca/bezerro

\begin{tabular}{lccc}
\hline $\begin{array}{l}\text { Variáveis } \\
\text { Independentes }\end{array}$ & Ingestão de MS, EM e PB & $\begin{array}{c}\text { Unidade vaca/bezerro } \\
\text { Eficiência energética }\end{array}$ & Eficiência protéica \\
\hline Peso vivo médio & - & $-0,34(0,04)$ & $-0,33(0,05)$ \\
Produção de leite & - & $0,44(0,01)$ & $0,36(0,03)$ \\
\hline
\end{tabular}

Significância das correlações entre parênteses;

em que: MS: matéria seca; EM: energia metabolizável; PB: proteína bruta. 
Os resultados deste trabalho analisaram o consumo, ganho, produção de leite e eficiência dos animais no período de aleitamento. Entretanto, os animais produzidos neste projeto temático foram avaliados por três anos em confinamento e a pasto com e sem suplementação.

Para que o resultado do cruzamento possa ser melhor avaliado é necessário que um esforço de modelagem seja conduzido para avaliar possíveis vantagens dos diferentes genótipos no período pós-desmama. Vários destes resultados já foram publicados (Cruz et al., 2000; Berndt et al. 2000, 2001) e serão avaliados conjuntamente com os dados deste trabalho.

As correlações com qualidade da carne e tamanho da carcaça produzida também são aspectos importantes e que foram avaliados nos trabalhos com estes mesmos animais no período pós-desmama.

É interessante também a condução de experimentos em condições limitantes de produção, que se aproximem da maioria das condições brasileiras. A obtenção de dados referentes ao desempenho reprodutivo das matrizes em ambiente desafiador indicaria os grupos mais eficientes quando a oferta de alimentos e demais condições ambientais não são ideais. 


\section{CONCLUSÕES}

As vacas cruzadas SN (Simental x Nelore) e AN (Angus x Nelore), de maior peso adulto e maior potencial de produção de leite apresentam maiores exigências de energia. Vacas Nelore apresentaram menor exigência diária para mantença do que as vacas SN, mas a exigência de mantença por unidade de peso metabólico não diferiu entre os grupos avaliados.

Os cruzamentos SN e AN não diferiram quanto ao tamanho adulto e quanto a ingestão diária de energia metabolizável ou por unidade de peso metabólico.

A ingestão de energia metabolizável da unidade vaca/bezerro $\mathrm{SN} / 1 \frac{1}{2} \mathrm{C} 1 / 4 \mathrm{~S} 1 / 4 \mathrm{~N}$ foi maior em relação aos demais, tendo o par Nelore/Nelore registrado a menor ingestão. Estes dados são consistentes com peso adulto, produção de leite e potencial de crescimento.

O maior peso ao desmame e maior quantidade de energia no corpo vazio dos bezerros $1 / 2 \mathrm{C}^{1} / 4 \mathrm{~A} 1 / 4 \mathrm{~N}$ mais do que compensaram a alta ingestão de energia do par vaca/bezerro comparado ao Nelore/Nelore.

Este trabalho, que não incluiu uma avaliação reprodutiva, sugere que em condições de alta disponibilidade de alimentos o cruzamento com B. taurus permite aumentar a produtividade e a eficiência de conversão de alimentos no setor de cria. 


\section{REFERÊNCIAS BIBLIOGRÁFICAS}

AGRICULTURAL RESEARCH COUNCIL. The nutrient requirements of farm livestock: ruminants, n.2. London: Agricultural Research Council, 1965. 1v.

AGRICULTURAL RESEARCH COUNCIL. The nutrient requirements of ruminant livestock: technical review. Farnham Royal: Commonwealth Agricultural Bureaux, 1980. 351p.

ALENCAR, M.M. Relação entre produção de leite da vaca e desempenho do bezerro nas raças Canchim e Nelore. Revista da Sociedade Brasileira de Zootecnia, v.18, n.2, p.146-156, 1989.

ALENCAR, M.M.; RUZZA, F.J.; PORTO, E.J.S. Desempenho produtivo de fêmeas da raça Canchim e Nelore. III. Produção de leite. Revista da Sociedade Brasileira de Zootecnia, v.17, n.4, p.317-328, 1988.

ALENCAR, M.M.; OLIVEIRA, F.T.T.; TAMBASCO, A.J.et al. Desenvolvimento pósdesmama e eficiência reprodutiva pós-parto em gado de corte: influência da produção de leite. Revista da Sociedade Brasileira de Zootecnia, v.22, n.6, p.1012-1018, 1993.

ANRIQUE, R. Body composition and efficiency of cattle as related to body type, size and sex. Ithaca, 1978. 211p. Thesis (Ph.D.) - Cornell University.

ARANGO, J.A.; VAN VLECK, L.D. Size of beef cows: early ideas, new developments. Genetics and Molecular Research, v.1, n.1, p.51-63, 2002. 
ARCHER, J.A.; RICHARDSON, E.C.; HERD, R.M. et al. Potential for selection to improve efficiency of feed use in beef cattle: A review. Australian Journal of Agricultural Research, v.50, p.147-161, 1999.

ARMSTRONG S.L.; WILTON, J.W.; SCHAEFFER, L.R. et al. Feed intake, weaning weight and net returns comparisons for four breeding systems. Journal of Animal Science, v.68, p.1848-1856, 1990.

ARTHUR, P. F.; ARCHER, J. A.; JOHNSTON, D. J. et al. Genetic and phenotypic variance and covariance components for feed intake, feed efficiency, and other postweaning traits in Angus cattle. Journal of Animal Science, v.79, p.2805-2811, 2001.

ASSOCIAÇÃO BRASILEIRA DOS CRIADORES DE BOVINOS DA RAÇA HOLANDESA. Regimento do serviço de controle leiteiro. São Paulo, 1986. 8p.

ASSOCIATION OF OFFICIAL AGRICULTURAL CHEMISTS. Official methods of analysis of AOAC International. 16. ed. Arlington, 1995. v.2, cap.33, p.10-11.

BAKER, F.S.; PALMER Jr., A.Z.; CARPENTER, J.W. Brahman x european crosses vs. british breeds. In: KOGER, M.; CUNHA, T.J.; WAINICK, P.C. (Ed.). Crossbreeding beef cattle. Gainesville: University of Florida Press, 1973. p.227-284.

BARBOSA, P.F. Análise genético-quantitativa de características de crescimento e reprodução em fêmeas da raça Canchim. Ribeirão Preto, 1991. 237p. Tese (Doutorado) - Faculdade de Medicina de Ribeirão Preto, Universidade de São Paulo.

BARBOSA, P.F.; ALENCAR, M.M. Sistema de cruzamento em bovinos de corte: Estado da arte e necessidade de pesquisa. In: REUNIÃO ANUAL DA SOCIEDADE BRASILEIRA DE ZOOTECNIA, 32., Brasília, 1995. Anais. Brasília: SBZ, 1995. p.681-683.

BEAL, W.E.; NOTTER, D.R.; AKERS, R.M. Techniques for estimation of milk yield in beef cows and relationships of milk yield to calf weight gain and postpartum reproduction. Journal of Animal Science, v.68, n.4, p.937-943, 1990. 
BERNDT, A.; HENRIQUE, W.; LEME, P.R. et al. Exigências de energia líquida para mantença e crescimento de tourinhos Santa Gertrudis em dietas de lato concentrado. In: REUNIÃO ANUAL DA SOCIEDADE BRASILEIRA DE ZOOTECNIA, 37., 2000. Anais. Viçosa: SBZ, 2000. p.444.

BERNDT, A.; CRUZ, G.M.; LANNA, D.P.D. et al. Composição física da 9-10a costelas de tourinhos de diferentes grupos genéticos em confinamento em relação ao status nutricional na fase de pastejo. In: REUNIÃO ANUAL DA SOCIEDADE BRASILEIRA DE ZOOTECNIA, 38., 2001. Anais. Piracicaba: SBZ, 2001. p.1302.

BLAXTER, K.L.; CLAPPERTON, J.L.; WAINMAN, F.W. Utilization of the energy and protein of the same diet by cattle of different ages. Journal of Agricultural Science, v.67, n.67, p.67-75, 1966.

BLACK, J. L. Animal growth and its regulation. Journal of Animal Science, v.66, suppl.3, p.1, 1988.

BOIN, C.; LANNA, D.P.D.; FOX, D.G. Avaliação DE DIETAS de bovines pelo sistema de carboidrato e proteína líquidos desenvolvido na Universidade de Cornell (CNCPS). In: SIMPÓSIO LATINO AMERICANO DE NUTRIÇÃO ANIMAL E SEMINÁRIO SOBRE TECNOLOGIA DA PRODUÇÃO, São Paulo, 1994. Anais. São Paulo: CBNA, 1994. p.89-102.

BREIREM, K.; HOMB, T. Energy requirements for growth. In: LENKAIT, W.; BREIREM, K.; CRASEMANN, E. (Ed.). Handbuch de Tierernahrung. Berlin: Verlag Paul Parey, 1982. 1v.

CHILD, C. M. Conformation and body composition. Progress in the physiology of farm animals. London: Butter worth, 1920, v.2, 430p.

CROOKER, B.A.; ANDERSON, P.T.; GOODRICH, R.D. Maintenance energy requirements and energetics of tissue deposition and mobilization in cattle. In: GRAZING LIVESTOCK NUTRITION CONFERENCE. Montana, 1991. Proceedings, s.l., s. ed., 1991, p.1-12. 
CRUZ, G.M. Produção de carne bovina utilizando confinamento. In: SIMPÓSIO SOBRE MANEJO E NUTRIÇÃO DE GADO DE CORTE, Goiânia, 2000. Anais. Goiânia: CBNA, 2000. p.91-106.

CRUZ, G.M.; ALENCAR, M.M.; TULLIO, R.R. Produção e composição do leite de vacas das raças Canchim e Nelore. Revista Brasileira de Zootecnia, v.26, n.5, p.887-893, 1997.

CUNDIFF, L.V.; GREGORY, K.E.; SCHWULST. et al. Effects of heterosis on maternal performance and milk production in Hereford, Angus and Shortorn cattle. Journal of Animal Science, v.38, p.728-745, 1974.

CUNDIFF, L.V.; FERRELL, C.L.; JENKINS, T.G. Output/Input differences among F1 cows of diverse biological type. Journal of Animal Science, v.57, suppl.1, p.148, 1983.

DELGADO, C.; ROSEGRANT, M.; STEINFELD, S. et al. Livestock to 2020: The next food revolution. Washington: International Food Policy Research Institute; FAO; ILRI, 1999. p.1-5. (Food, Agriculture, and the Environment Discussion Paper, 28).

DeNISE, R.S.K.; BRINKS, J.S.; RICHARDSON, G.V. Relationships among growth curve parameters and selected productivity traits in beef cows. Journal of Animal Science, v.57, suppl.1, p.149, 1983.

DICKERSON, G. Efficiency of animal production - molding the biological components. Journal of Animal Science, v.30, p.849-859, 1970.

DICKERSON, G.E. Animal size and efficiency: basic concepts. Animal Production, v.27, p.367-379, 1978.

DICKERSON, G.E.; KÜNZI, N.; CUNDIFF, L.V. et al. Selection criteria for efficient beef production. Journal of Animal Science, v.39, p.659-673, 1974.

DINKEL, C.A.; BROWN, M.A. An Evaluation of the ratio of calf weight to cow weight as an indicator of cow efficiency. Journal of Animal Science, v.46, p.614-617, 1978. 
EUCLIDES FILHO, K.; FIGUEIREDO, G. R. Desempenho de sistemas de produção com vacas F1s de diferentes tamanhos adultos. <http://www.cnpgc.embrapa.br/eventos/2000/dcvacasgrandes/apostila.html> (27 dez. 2001).

EVANS, J.L.; GOLDEN, B.L.; HOUGH, B.L. A new genetic prediction for cow maintenance energy requirements. In: ANNUAL RESEARCH SYMPOSIUM \& ANNUAL MEETING, 33., San Antonio, 2001. Proceedings, s.l.: BIF, 2001, p.109114.

FERRELL, C.L. Effects of postweaning rate of gain on onset of puberty and productive performance of heifers of different breeds. Journal of Animal Science, v.55, p.12721283, 1982.

FERRELL, C.L. Contribution of visceral organs to animal energy expenditures. Journal of Animal Science, v.66, suppl.3, p.23-34, 1988.

FERRELL, C.L.; JENKINS, T.G. Relationships among various body components of mature cows. Journal of Animal Science, v.58, p.234-243, 1984.

FERRELL, C.L.; JENKINS, T.G. Energy utilization by Hereford and Simmental males and females. Animal Production, v.40, n. 3, p.725-741, 1985.

FERRELL, C. L.; JENKINS, T. G. Energy Expenditures of mature cows during the production cycle. Beef Research Progress Report, n.4, p.118, 1993.

FERRELL, C.L.; GARRETT, W.N.; HINMAN, N. et al. Energy utilization by pregnant and non-pregnant heifers. Journal of Animal Science, v.42, p.937-950, 1976.

FITZHUGH Junior, H.A.; LONG, C.A.; CARTQRIGHT, T.C. System analysis of sources of genetic and environmental variation in efficiency of beef production: heterosis and complementarity. Journal of Animal Science, v.40, n.3, p.421-432, 1975. 
FOX, D.G.; GEORGE, P.D. Feeding beef cows and their nursing calves. Cooperative Extension Service, Cornell University, n.1300b, p. 1-20, 1986. (Cornell Beef Production Reference Manual).

FOX, D.G.; SNIFFEN, C.J.; O’CONNOR, J.D. et al. A net carbohydrate and protein system for evaluating cattle diets. III. Cattle requirements and diet adequacy. Journal of Animal Science, v.70, p.3578-3596, 1992.

FRISCH, J.E. Comparative drought resistance of Bos indicus and Bos taurus crossbred herds in central Queensland. 2. Relative mortality rates calf birth weights and weight changes in breeding cows. Australia Journal of Experimental Agricultural Animal Husbandry, v.13, p.117, 1973.

FRISCH, J.E.; VERCOE, J.E. Maintenance requirement, fasting metabolism and body composition in different cattle breeds. Energy metabolism Proceeding Symposium, v.19, p.209, 1977.

FRISCH, J.E.; VERCOE, J.E. The effect of previous exposure to parasites on the fasting metabolism and feed intake of three cattle breeds. Energy metabolism Proceeding Symposium, v.29, p.100-103, 1982.

GAINES, W.L. The energy basis of measuring milk yield in dairy cows. Agricultural Experimental Station, Champaign: University of Illinois, 1928, (Bulletin, 308).

GALVÃO, J.G.; FONTES, C.A.A.; PIRES, C.C. et al. Características e composição física da carcaça de bovinos não-castrados, abatidos em três estágios de maturidade (estudo II) de três grupos raciais. Revista da Sociedade Brasileira de Zootecnia, v.20, n.5, p.502-512, 1991.

GRAHAM, N. McC. Variation in energy and nitrogen utilization by sheep between weaning and maturity. Australian Journal of Agricultural Research, v.31, p.335345, 1980. 
GRAHAM, N. McC.; SEARLE, T.W.; GRIFFITHS, D.A. Basal metabolic rate in lambs and young sheep. Australian Journal of Agricultural Research, v.25, p.957-971, 1974.

GREEN, R.D.; CUNDIFF, L.V.; DICKERSON, G.E. et al. Output/input differences among nonpregnant, lactating Bos indicus-Bos taurus and Bos taurus-Bos taurus F1 cross cows. Journal of Animal Science, v.69, p.3156-3166, 1991.

HANKINS, O.G.; HOWE, P.E. Estimation of the composition of beef carcass cuts. Washington: USDA, 1946, p.1-20, (Bulletin Technical, 26).

HENRIQUE, W.; SAMPAIO, A.A. M.; LEME, P.R. et al. Estimativa da composição química corporal de tourinhos Santa Gertrudes a partir da composição química e física das 9- 10- $11^{\mathrm{a}}$ costelas. Revista Brasileira de Zootecnia, v.32, n.3, p.709-718, 2003.

HERD, R.M.; BISHOP, S.C. Genetic variation in residual feed intake and its association with other production traits in british Hereford cattle. Livestock Production Science, v.63, p.111-119, 2000.

HERRING, W.O.; BERTRAND, J.K. Multi-trait prediction of feed conversion in feedlot cattle. In: ANNUAL BEEF IMPROVEMENT FEDERATION ANNUAL MEETING, $34 . \quad$ Omaha, $2002 . \quad$ Proceedings. <http://www.beefimprovement.org/proceedings $>$ (14 nov. 2003).

HORN, A. Possibilits of improving efficiency and evaluation of economic production in dual purpose cattle with special reference to the hungarian fleckvieh. World Review of Animal Production, v.3, n.12, p.35-44, 1967.

HOTOVY, S.K.; JOHNSON, K.A.; JOHNSON, D.E. et al. Variation among twin beef cattle in maintenance energy requirements. Journal of Animal Science, v.69, p.940946, 1991. 
JENKINS, T,G.; FERREL, C.L. Nutrient requirements to maintain weight of mature, nonlacting, nonpregnant cows of four diverse breed types. Journal of Animal Science, v.56, p.761-770, 1983.

JENKINS, T.G.; FERRELL, C.L. Conversion efficiency trough weaning of nine breeds of cattle. Beef Research, Progress Report, n.4, p.156-157, 1993.

JENKINS, T.G.; FERREL, C.L.; CUNDIFF, L.V. Relationship of components of the body among mature cows as related to size, lactation potential and possible effects on productivity. Animal Production, v.43, p.245, 1986.

JENKINS, T.G.; CUNDIFF, L.V.; FERRELL, C.L. Differences among breed crosses of cattle in the conversion of food energy to calf weight during the preweaning interval. Journal of Animal Science, v.69, p.2762-2769, 1991.

JOHNSTON, D. Genetic prediction of efficiency in the future: an Australian perspective. In: ANNUAL BEEF IMPROVEMENT FEDERATION ANNUAL MEETING, $34 . \quad$ Omaha, 2002. Proceedings. <http://www.beefimprovement.org/proceedings > (14 nov. 2003).

KLOSTERMAN, E.W.; SANFORD, L.G.; PARKER, C.F. Effect of cow size and condition and ration protein content upon maintenance requirements of mature beef cows. Journal of Animal Science, v.27, p.242, 1968.

KOOTS, K.R.; GIBSON, J.P.; SMITH, C. et al. Analyses of published genetic parameter estimates for beef production traits. 1.Heritability. Animal Breeding Abstracts, v.62, n.5, p.309, 1994.

LANNA, D.P.D. Estimativa da composição química do corpo vazio de tourinhos Nelore através da gravidade específica da carcaça e da composição de cortes das costelas. Piracicaba, 1988. 131p. Dissertação (Mestrado) - Escola Superior de Agricultura “Luiz de Queiroz”, Universidade de São Paulo. 
LANNA, D.P.D. Eficiência biológica e econômica de bovinos de corte. In: CONVENÇÃO NACIONAL DA RAÇA CANCHIM, 2000. Anais. São Carlos: Embrapa Pecuária Sudeste, p.52-64.

LANNA, D.P.D.; FOX, D.G.; BOIN, C. et al. Validation of the CNCPS estimates of nutrient requirements of growing and lactating zebu germplasm in tropical conditions. Journal of Animal Science. v.76, suppl.1, p. 287, 1996.

LANNA, D.P.D.; TEDESCHI, L.O.; BELTRAME FILHO, E.J.A. Modelos lineares e não lineares de uso de nutrientes para formulação de dietas de ruminantes. Scientia Agrícola, v.56, n.2, p.479-488, 1999.

LISTER, D.; PERRY, B.N.; WOOD, J.D. Meat production. In: ROOK, J.A.F.; THOMAS, P.C. (Ed.). Nutritional Physiology of Farm Animals. London: Longman, 1983. p.447-537.

LOFGREEN, G.P. A comparative slaughter technique for determining net energy values with beef cattle. Energy Metabolism Proceedings Symposium, v.11, p.309-317, 1965.

LOFGREEN, G.P.; GARRET, W.N. A system for expressing net energy requirements and feed values from growing and finishing cattle. Journal of Animal Science, v.27, p.793-806, 1968.

LONG, C.R.; CARTWRIGHT, T.C.; FITZHUGH Junior, H.A. System analysis of sources of genetic and environmental variation in efficiency of beef production: cow size and herd management. Journal of Animal Science, v.40, n.3, p.410-420, 1975.

MANZANO, A.; ESTEVES, S.N.; FREITAS, A.R. et al. Eficiência de utilização de nutrientes em novilhas das raças Canchim e Nelore e cruzadas Canchim-Nelore. Revista Brasileira de Zootecnia, v.28, n.6, p.1375-1381, 1999.

MARIANTE, A.S. Growth and reproduction in Nelore cattle in Brazil: genetic parameters and effects of environmental factors. Gainesville, 1978. 131p. Thesis (Ph.D.) - University of Florida. 
McMORRIS, C.A.; WILTON, W. Influence of body size on the biological efficiency of cows: a review. Canadian Journal Animal Science, v.56, n.4, p.613-647, 1976.

METCALF, J.A.; WRAY-CAHEN, D.; CHETTLE, E.E. et al. The effect of dietary crude protein as protected soybean meal on mammary metabolism in the lactating dairy cow. Journal of Dairy Science, v.79, p.603-611, 1996.

MONTAÑO-BERMUDEZ, M.; NIELSEN, M.K. Biological efficiency to weaning and to slaughter of crossbred beef cattle with different genetic potential for milk. Journal of Animal Science, v.68, p.2297-2309, 1990.

MONTAÑO-BERMUDEZ, M.; NIELSEN, M.K.; DEUTSCHER, G.H. Energy requirements for maintenance of crossbred beef cattle with different genetic potential for milk. Journal of Animal Science, v.68, p.2279-2288, 1990.

MORAN, J.B. The grazing feeds intake of Hereford and Brahman cross cattle in a cool temperature environment. Journal of Agricultural Science, v.86, p.131-138, 1976.

NATIONAL RESEARCH COUNCIL. Nutrient requirements of beef cattle, 5 ed. Washington: National Academy of Sciences, 1976. 74p.

NATIONAL RESEARCH COUNCIL. Nutrient requirements of beef cattle, 6 ed. Washington: National Academy Press, 1984. 90p.

NATIONAL RESEARCH COUNCIL. Nutrient requirements of dairy cattle, 6 ed. Washington: National Academy Press, 1989. 158p.

NATIONAL RESEARCH COUNCIL. Nutrient requirements of beef cattle, 7 ed. Washington: National Academy Press, 1996. 234p.

NATIONAL RESEARCH COUNCIL. Nutrient requirements of dairy cattle, 7 ed. Washington: National Academy Science, 2001. 381p.

NEVILLE, W.E. Comparison of energy requirements of nonlacting and lacting Hereford cows and estimates of energetic efficiency of milk production. Journal of Animal Science, v.38, p.681-686, 1974. 
NOTTER, D.R. Defining biological efficiency of beef production. In: ANNUAL RESEARCH SYMPOSIUM \& ANNUAL MEETING, 34., Proceedings. s.l.: BIF, 2000, p.8-20.

NOTTER, D.R.; SANDERS, J.O.; DICKERSON, G.E. et al. Simulated efficiency of beef production for midwestern cow-calf-feedlot management system. II Mature body size. Journal of Animal Science, v.49, n.1, p.83-91, 1979.

REID, J. T. Will meat, milk and egg production be possible in the future? In: CORNELL NUTRITION CONFERENCE FOR FEED MANUFACTURERS, p.50-63, 1970.

REYNOLDS, C.K. Economics of visceral energy metabolism in ruminants: toll keeping or internal revenue service? Journal of Animal Science, v.80, suppl.2, p.E74-E84, 2002.

REYNOLDS, C.K.; TYRRELL, H.F. Energy metabolism in lactating beef heifers. Journal of Animal Science, v.78, p.2696-2705, 2000.

SANTOS, J.E.P.; AMSTALDEN, M. Effects of nutrition on bovine reproduction. Arquivo da Faculdade de Veterinária, v.26, n.1, p.19-89, 1998.

SAS. INSTITUTE. SAS/STAT. Guide for personal computers. Cary, 2000. 1v.

SILVA, A.M.; ALENCAR, M.M.; FREITAS, A.R. et al. Herdabilidades e correlações genéticas para peso e perímetro escrotal de machos e características reprodutivas e de crescimento de fêmeas, na raça Canchim. Revista Brasileira de Zootecnia, v.29, n.6, p.2223-2230, 2000.

SIMPFENDORFER, S. Relationship of body type and size, sex, and energy intake to the body composition of cattle. Ithaca, 1974. 193p. Thesis (Ph.D.) - Cornell University.

SMITH, N.E. Quantitative simulation analyses of ruminant metabolic functions: basal, lactation, milk fat depression. Davis, 1970. 231p. Thesis (Ph.D.) - University of California. 
SMITH, G.M.; LASTER, D.B.; CUNDIFF, L.V. Caracterization of biological types of cattle. II. Post-weaning growth and feed efficiency of steers. Journal of Animal Science, v.43, n.1, p.37-47, 1976.

SOLIS, J.C.; BYERS, F.M.; SCHELLING, G.T. et al. Maintenance requirements and energetic efficiency of cows of different breed types. Journal of Animal Science, v.66, p.764-773, 1988.

TAYLOR, C.S. Lectures on mammalian growth. In: SIMPOSIUM OF INSTITUTE OF ANIMAL PHYSIOLOGY AND GENETICS RESEARCH, Guelph, 1989. Proceedings. Guelph: University of Guelph, 1989. p.51-64.

TAYLOR, C.S.; TURNER, H.G.; YOUNG, G.B. Genetic control of equilibrium maintenance efficiency in cattle. Animal Production, v.33, p.179-194, 1981.

TAYLOR, C.S.; THIESSEN, R.B.; MURRAY, J. Inter-breed relationship of maintenance efficiency to milk yield in cattle. Animal Production, v.43, p.37-61, 1986.

TEDESCHI, L.O. Determinação dos parâmetros da curva de crescimento de animais da raça Guzerá e seus cruzamentos sem suplementação, com suplementação durante o inverno e suplementação durante o ano. Piracicaba, 1996. 140p. Dissertação (Mestrado) - Escola Superior de Agricultura “Luiz de Queiroz”, Universidade de São Paulo.

TEDESCHI, L.O.; BOIN, C.; FOX, D.G. et al. Energy requirement for maintenance and growth of Nellore bulls and steers fed high-forage diets. Journal of Animal Science, v.80, p.1671-1682, 2002.

TESS, M.W.; DAVIS, K.C. Gordon Dickerson: defining economic efficiency of beef production. In: ANNUAL RESEARCH SYMPOSIUM AND ANNUAL MEETING, 34., Omaha, 2002. Proceedings. Omaha: BIF, 2002, p.21-31. 
THOMPSON, G.E.; BELL, A.W. The energy metabolism of the liver measured in vivo during cold exposure of sheep. European Association Animal Production (Ed), Energy Metabolism of Farm Animals, v.19, p.37, 1976.

TRUSCOTT, T.G.; WOOD, J.D.; GREGORY, N.G. et al. Fat deposition in Hereford and Friesian steers. Journal of Agricultural Science, v.100, n.2, p.271-276, 1983.

VAN SOEST, P. J. Nutritional ecology of the ruminant. 2 ed. London: Comstock Publishing Association, 1994. 476p.

VERMOREL, M.; BOUVIER, J.C.; GEAY, Y. The effect of genetic type (normal and double-muscled Charolais and Friesian) on energy utilization by growing cattle at 2 and 16 months of age. Energy Metabolism Proceedings Symposium, v.19, p.217220, 1976.

WEBSTER, A.J.F. Energy metabolism and requirements. In: CHURCH, D. C. (Ed.) Digestive physiology and nutrition of ruminants. 2 ed. Oregon: Book Stores, 1979. p.210-229.

WEISS, W.P.; CONRAD, H.R.; PIERRE, R.R.S. A Theoretically - based model for predicting total digestible nutrient values of forages and concentrates. Animal Feed Science Technology, v.39, p.95-110, 1992.

WILTON, J.W.; MORRIS, C.A.; JENSON, E.A. et al. A linear programming model for beef cattle production. Canadian Journal of Animal Science, v.54, p.693, 1974. 